\title{
Dietary interventions for adults with chronic kidney disease
} (Review)

Palmer SC, Maggo JK, Campbell KL, Craig JC, Johnson DW, Sutanto B, Ruospo M, Tong A, Strippoli GFM

Palmer SC, Maggo JK, Campbell KL, Craig JC, Johnson DW, Sutanto B, Ruospo M, Tong A, Strippoli GFM. Dietary interventions for adults with chronic kidney disease.

Cochrane Database of Systematic Reviews 2017, Issue 4. Art. No.: CD011998.

DOI: 10.1002/14651858.CD011998.pub2.

www.cochranelibrary.com 
TABLE OF CONTENTS

HEADER 1

ABSTRACT

PLAIN LANGUAGE SUMMARY

SUMMARY OF FINDINGS

BACKGROUND

OBJECTIVES

METHODS

RESULTS

Figure 1.

Figure 2.

Figure 3.

DISCUSSION

AUTHORS' CONCLUSIONS

ACKNOWLEDGEMENTS

REFERENCES

CHARACTERISTICS OF STUDIES

DATA AND ANALYSES

Analysis 1.1. Comparison 1 Dietary intervention versus control, Outcome 1 All-cause mortality.

Analysis 1.2. Comparison 1 Dietary intervention versus control, Outcome 2 Cardiovascular mortality.

Analysis 1.3. Comparison 1 Dietary intervention versus control, Outcome 3 Health-related quality of life (SF-36) score. ..........

Analysis 1.4. Comparison 1 Dietary intervention versus control, Outcome 4 End-stage kidney disease.

Analysis 1.5. Comparison 1 Dietary intervention versus control, Outcome 5 Doubling of serum creatinine.

Analysis 1.6. Comparison 1 Dietary intervention versus control, Outcome 6 Employment.

Analysis 1.7. Comparison 1 Dietary intervention versus control, Outcome 7 Dietary adherence.

Analysis 1.8. Comparison 1 Dietary intervention versus control, Outcome 8 Worsening nutrition.

Analysis 1.9. Comparison 1 Dietary intervention versus control, Outcome 9 eGFR [mL/min/1.73 m2].

Analysis 1.10. Comparison 1 Dietary intervention versus control, Outcome 10 Serum creatinine.

Analysis 1.11. Comparison 1 Dietary intervention versus control, Outcome 11 Systolic blood pressure.

Analysis 1.12. Comparison 1 Dietary intervention versus control, Outcome 12 Diastolic blood pressure.

Analysis 1.13. Comparison 1 Dietary intervention versus control, Outcome 13 Energy intake.

Analysis 1.14. Comparison 1 Dietary intervention versus control, Outcome 14 Body weight.

Analysis 1.15. Comparison 1 Dietary intervention versus control, Outcome 15 BMI.

Analysis 1.16. Comparison 1 Dietary intervention versus control, Outcome 16 Waist-hip ratio.

Analysis 1.17. Comparison 1 Dietary intervention versus control, Outcome 17 Waist circumference, $\mathrm{cm}$. .................................

Analysis 1.18. Comparison 1 Dietary intervention versus control, Outcome 18 Arm circumference.

Analysis 1.19. Comparison 1 Dietary intervention versus control, Outcome 19 Serum albumin.

Analysis 1.20. Comparison 1 Dietary intervention versus control, Outcome 20 Serum LDL cholesterol.

Analysis 2.1. Comparison 2 Mediterranean diet versus low fat, Outcome 1 Serum LDL cholesterol.

Analysis 3.1. Comparison 3 Fruits and vegetables versus bicarbonate, Outcome 1 eGFR [mL/min/1.73 m2].

Analysis 3.2. Comparison 3 Fruits and vegetables versus bicarbonate, Outcome 2 Serum creatinine.

Analysis 3.3. Comparison 3 Fruits and vegetables versus bicarbonate, Outcome 3 Systolic blood pressure.

Analysis 3.4. Comparison 3 Fruits and vegetables versus bicarbonate, Outcome 4 Body weight.

ADDITIONAL TABLES

APPENDICES

CONTRIBUTIONS OF AUTHORS

DECLARATIONS OF INTEREST

DIFFERENCES BETWEEN PROTOCOL AND REVIEW

INDEX TERMS 
[Intervention Review]

\section{Dietary interventions for adults with chronic kidney disease}

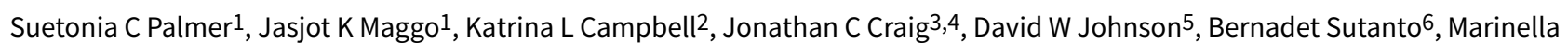
Ruospo 7,8, Allison Tong3,6, Giovanni FM Strippoli3,4,7,9,10

1Department of Medicine, University of Otago Christchurch, Christchurch, New Zealand. 2Faculty of Health Science and Medicine, Bond University, Robina, Australia. ${ }^{3}$ Sydney School of Public Health, The University of Sydney, Sydney, Australia. ${ }^{4}$ Cochrane Kidney and Transplant, Centre for Kidney Research, The Children's Hospital at Westmead, Westmead, Australia. ${ }^{5}$ Department of Nephrology, Princess Alexandra Hospital, Woolloongabba, Australia. ${ }^{6}$ Centre for Kidney Research, The Children's Hospital at Westmead, Westmead, Australia. 7 Medical Scientific Office, Diaverum, Lund, Sweden. 8Division of Nephrology and Transplantation, Department of Translational Medicine, Amedeo Avogadro University of Eastern Piedmont, Novara, Italy. ${ }^{9}$ Department of Emergency and Organ Transplantation, University of Bari, Bari, Italy. ${ }^{10}$ Diaverum Academy, Bari, Italy

Contact address: Giovanni FM Strippoli, Cochrane Kidney and Transplant, Centre for Kidney Research, The Children's Hospital at Westmead, Westmead, NSW, 2145, Australia.giovanni.strippoli@uniba.it, gfmstrippoli@gmail.com.

Editorial group: Cochrane Kidney and Transplant Group.

Publication status and date: New, published in Issue 4, 2017.

Citation: Palmer SC, Maggo JK, Campbell KL, Craig JC, Johnson DW, Sutanto B, Ruospo M, Tong A, Strippoli GFM. Dietary interventions for adults with chronic kidney disease. Cochrane Database of Systematic Reviews 2017, Issue 4. Art. No.: CD011998. DOI: 10.1002/14651858.CD011998.pub2.

Copyright $@ 2017$ The Cochrane Collaboration. Published by John Wiley \& Sons, Ltd.

\section{A B S T R A C T}

\section{Background}

Dietary changes are routinely recommended in people with chronic kidney disease (CKD) on the basis of randomised evidence in the general population and non-randomised studies in CKD that suggest certain healthy eating patterns may prevent cardiovascular events and lower mortality. People who have kidney disease have prioritised dietary modifications as an important treatment uncertainty.

\section{Objectives}

This review evaluated the benefits and harms of dietary interventions among adults with CKD including people with end-stage kidney disease (ESKD) treated with dialysis or kidney transplantation.

\section{Search methods}

We searched the Cochrane Kidney and Transplant Specialised Register (up to 31 January 2017) through contact with the Information Specialist using search terms relevant to this review. Studies contained in the Specialised Register are identified through search strategies specifically designed for CENTRAL, MEDLINE, and EMBASE; handsearching conference proceedings; and searching the International Clinical Trials Register (ICTRP) Search Portal and ClinicalTrials.gov.

\section{Selection criteria}

Randomised controlled trials (RCTs) or quasi-randomised RCTs of dietary interventions versus other dietary interventions, lifestyle advice, or standard care assessing mortality, cardiovascular events, health-related quality of life, and biochemical, anthropomorphic, and nutritional outcomes among people with CKD.

\section{Data collection and analysis}

Two authors independently screened studies for inclusion and extracted data. Results were summarised as risk ratios (RR) for dichotomous outcomes or mean differences (MD) or standardised MD (SMD) for continuous outcomes, with 95\% confidence intervals (CI) or in descriptive format when meta-analysis was not possible. Confidence in the evidence was assessed using GRADE. 


\section{Main results}

We included 17 studies involving 1639 people with CKD. Three studies enrolled 341 people treated with dialysis, four studies enrolled 168 kidney transplant recipients, and 10 studies enrolled 1130 people with CKD stages 1 to 5 . Eleven studies (900 people) evaluated dietary counselling with or without lifestyle advice and six evaluated dietary patterns (739 people), including one study (191 people) of a carbohydrate-restricted low-iron, polyphenol enriched diet, two studies (181 people) of increased fruit and vegetable intake, two studies (355 people) of a Mediterranean diet and one study (12 people) of a high protein/low carbohydrate diet. Risks of bias in the included studies were generally high or unclear, lowering confidence in the results. Participants were followed up for a median of 12 months (range 1 to 46.8 months).

Studies were not designed to examine all-cause mortality or cardiovascular events. In very-low quality evidence, dietary interventions had uncertain effects on all-cause mortality or ESKD. In absolute terms, dietary interventions may prevent one person in every 3000 treated for one year avoiding ESKD, although the certainty in this effect was very low. Across all 17 studies, outcome data for cardiovascular events were sparse. Dietary interventions in low quality evidence were associated with a higher health-related quality of life ( 2 studies, 119 people: MD in SF-36 score $11.46,95 \% \mathrm{Cl} 7.73$ to $15.18 ; \mathrm{I}^{2}=0 \%$ ). Adverse events were generally not reported.

Dietary interventions lowered systolic blood pressure (3 studies, 167 people: $\mathrm{MD}-9.26 \mathrm{~mm} \mathrm{Hg}, 95 \% \mathrm{Cl}-13.48$ to $-5.04 ; \mathrm{I}^{2}=80 \%$ ) and diastolic blood pressure ( 2 studies, 95 people: MD $-8.95,95 \% \mathrm{Cl}-10.69$ to $-7.21 ; 1^{2}=0 \%$ ) compared to a control diet. Dietary interventions were associated with a higher estimated glomerular filtration rate (eGFR) (5 studies, 219 people: SMD 1.08; $95 \% \mathrm{Cl} 0.26$ to $1.97 ; \mathrm{I}^{2}=88 \%$ ) and serum albumin levels ( 6 studies, 541 people: MD $0.16 \mathrm{~g} / \mathrm{dL}, 95 \% \mathrm{Cl} 0.07$ to $0.24 ; \mathrm{I}^{2}=26 \%$ ). A Mediterranean diet lowered serum LDL cholesterol levels ( 1 study, 40 people: MD $-1.00 \mathrm{mmol} / \mathrm{L}, 95 \% \mathrm{Cl}-1.56$ to -0.44 ).

\section{Authors' conclusions}

Dietary interventions have uncertain effects on mortality, cardiovascular events and ESKD among people with CKD as these outcomes were rarely measured or reported. Dietary interventions may increase health-related quality of life, eGFR, and serum albumin, and lower blood pressure and serum cholesterol levels.

Based on stakeholder prioritisation of dietary research in the setting of CKD and preliminary evidence of beneficial effects on risks factors for clinical outcomes, large-scale pragmatic RCTs to test the effects of dietary interventions on patient outcomes are required.

\section{PLAIN LANGUAGE SUMMARY}

\section{Dietary patterns for adults with chronic kidney disease}

\section{What is the issue?}

People who have kidney disease can experience a lower life expectancy, complications including heart disease, and may need treatment for severe kidney failure, such as dialysis. Patients and doctors wish to identify treatments that protect people against kidney failure or heart disease. For both doctors and people who have kidney disease, lifestyle changes such as diet are very important as possible ways to improve health and well-being, and provide people with a chance to 'self-manage' their care for kidney disease.

\section{What did we do?}

We combined all studies looking at dietary changes for people who kidney disease including people treated with dialysis or who have a kidney transplant.

\section{What did we find?}

We found 17 studies involving 1639 people who had chronic kidney disease that looked into whether diet changes or advice improved their health. Studies included men and women with mainly moderate or severe kidney disease. Diets involved increasing fruit and vegetable intake, increasing poultry and fish, higher nut and olive oil use, and some increases in cereals and legumes (e.g. beans), and less red meat, sugar, and salt. We looked particularly at three key outcomes: the risk of death, the risk of advanced kidney disease requiring dialysis, and quality of life. There were four studies involving people who have had a kidney transplant and three studies involving people treated with dialysis.

After combining the available studies, it was uncertain whether making healthy diet changes prevented heart complications as most studies did not measure these. Diet changes may improve life quality. We did see that some risk factors for future disease, such as blood pressure and cholesterol, were lower following diet counselling or healthier eating.

The quality of the included studies was often very low meaning we could not be sure that future studies would find similar results.

\section{Conclusions}


We are very uncertain whether dietary changes improve well-being for people with kidney disease because the available research studies were not designed to learn about these. Diet changes may lower blood pressure and cholesterol, but the longer term impact of these effects on well-being is not proven. This means we still need large and good-quality research studies to help understand the impact of diet on the health of people with kidney disease. 


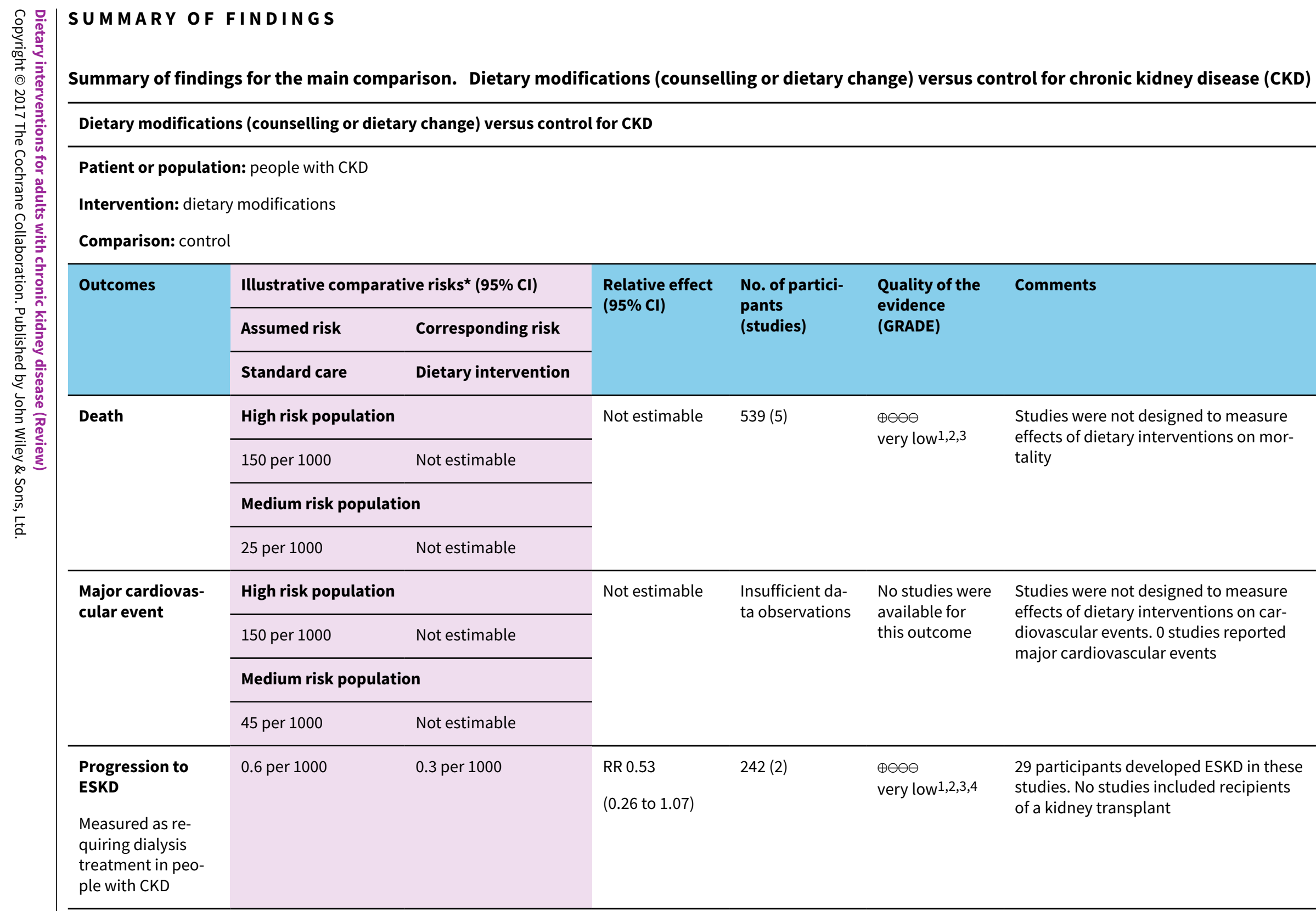


Health-related quality of life

Measured using the Short Form-36 scale from 0 to 100

\section{The mean SF-36}

score ranged across

control groups from

43.6 to 48.8

$$
\begin{aligned}
& \text { The mean SF-36 score } \\
& \text { in the intervention } \\
& \text { groups was } 11.46 \text { high- } \\
& \text { er ( } 95 \% \mathrm{Cl} 7.73 \text { to } \\
& 15.18)
\end{aligned}
$$

$\oplus \oplus \ominus \ominus$

low 1,3
0 studies included recipients of a kidney transplant. None of the studies were blinded

*The basis for the assumed risk of mortality (e.g. the median control group risk across studies) was obtained from the absolute population risk estimated from previously published cohort studies or data registries (Johnson 2011; Weiner 2006). The corresponding risk (and its $95 \%$ confidence interval) is based on the assumed risk in the comparison group and the relative effect of the intervention (and its $95 \% \mathrm{Cl}$ ).

Cl: Confidence interval; RR: Risk Ratio

GRADE Working Group grades of evidence

High quality: Further research is very unlikely to change our confidence in the estimate of effect.

Moderate quality: Further research is likely to have an important impact on our confidence in the estimate of effect and may change the estimate.

Low quality: Further research is very likely to have an important impact on our confidence in the estimate of effect and is likely to change the estimate.

Very low quality: We are very uncertain about the estimate.

1 Study limitations were due to high or unclear risks of bias

2 Confidence interval includes range of plausible values that include substantial benefit or harm

3 Based on few events and/or participants across all studies

4 Data not available for recipients of a kidney transplant 


\section{B A C K G R O U N D}

\section{Description of the condition}

Chronic kidney disease (CKD) is a disorder resulting from structural changes to the kidney (cysts, loss of tissue, or masses) and/or urinary tract leading to changes in the composition of the urine, reduced kidney function or both. The kidney is a target organ injured in diseases primary to the kidney (such as glomerulonephritis or polycystic kidney disease) and secondary diseases (including cardiovascular disease, metabolic syndrome, diabetes (predominantly type 2), obesity, and arterial hypertension). Secondary causes of kidney failure now dominate the global epidemiology of kidney disease - diabetes and hypertension are the leading causes of CKD in middle and higher income countries worldwide, accounting for approximately $35 \%$ and $25 \%$ of kidney disease (Jha 2013). Kidney tissue in systemic diseases is injured by accelerated vascular damage, glomerular hypertension, and increased cellular glycosylation and oxidation.

Overall, CKD affects an estimated $10 \%$ to $15 \%$ of people around the world (Chadban 2003; Singh 2009; Zhang 2012) and leads to poorer health outcomes for affected individuals and communities. Among people who have moderate to severe CKD, early death and cardiovascular complications are two to three times more likely than for people without kidney disease and quality of life is reduced (Go 2004; Hemmelgarn 2010; Wyld 2012).

\section{Description of the intervention}

Dietary modifications (dietary intake of whole foods rather than single dietary nutrients, such as sodium or protein) may play an important and complex role in the aetiology and progression of CKD, in part through modification of systemic disease processes affecting kidney function (arterial hypertension, tissue glycosylation, glomerular injury, and macrovascular and microvascular diseases) and in part through altering the risks of non-communicable diseases such as diabetes that play such an important role in the prevalence of kidney disease in developed and developing nations. Individual dietary components may influence blood lipid levels, oxidative stress, insulin sensitivity, blood pressure, systemic inflammatory responses, pro fibrotic processes, thrombosis risk, and endothelial function to modify clinical outcomes (Abiemo 2012; Nakayama 1996; Peters 2000; Stamler 1996; van Dijk 2012).

\section{How the intervention might work}

While the exact mechanisms through which dietary modifications might act to prolong life expectancy and kidney function are likely to be multifactorial, there is emerging evidence showing the impact of dietary changes on risk factors for kidney injury and cardiovascular disease. In recent Cochrane reviews of dietary advice in primary and secondary prevention studies predominantly through reduction of salt and fat intake and increased fruit, vegetables, and fibre intake - dietary changes reduced arterial blood pressure by up to $10 \mathrm{~mm} \mathrm{Hg}$ on average, as well as serum cholesterol and sodium excretion (Hartley 2013; Rees 2013a; Rees 2013b).

Combined dietary and exercise interventions among people at risk of diabetes, many of whom have kidney disease, reduce weight and body mass and have modest effects on blood lipids and blood pressure, while altered carbohydrate or energy intake plus exercise improves glycaemic control in people with type 2 diabetes (Nield 2008; Orozco 2008). Intensive advice and support to reduce salt intake may have small and unsustained effects on blood pressure (Adler 2014) of uncertain clinical importance. Among people at high cardiovascular risk, a Mediterranean diet increases circulating anti-oxidant levels, which has been proposed as one possible mechanism for improved survival (Zamora-Ros 2013). Whether dietary alteration of risks factors for cardiovascular events including blood pressure, serum lipids, or anti-oxidant levels modify clinical outcomes for people with CKD remains uncertain.

\section{Why it is important to do this review}

Although numerous randomised controlled trials (RCTs) in people with CKD have evaluated single nutrient management (such as protein intake or salt intake), there is relatively less information about the impact of whole dietary modifications - for example, the Mediterranean diet or Dietary Approaches to Stop Hypertension (DASH) diet - on clinical outcomes in people with CKD. Clinical studies in this area have been largely restricted to modifying protein, sodium, and phosphorus dietary intake as well as antioxidant supplementation (Fouque 2009; Jun 2012; Liu 2015; McMahon 2015). Among people with CKD, lowered dietary salt intake reduced blood pressure and the amount of protein excreted by the kidney (an indicator of cardiovascular risk) (McMahon 2015), although there was no high-quality evidence this translated to slower kidney disease progression or fewer cardiovascular complications. Although dietary interventions in the setting of CKD have commonly focused on protein restriction as a mechanism to slow kidney failure, there is limited evidence that this dietary strategy is effective and safe and the impact of different protein sources on clinical outcomes is poorly understood (Robertson 2007; Fouque 2009).

Global clinical guidelines recommend dietary strategies in the management of CKD (KDIGO 2012). Specifically, guidelines suggest lower protein intake with appropriate education and avoiding high protein intake for people at risk of kidney disease progression, lower salt intake, and increased physical activity (aiming for at least 30 minutes, 5 times/week). Guidelines recommend that people with CKD receive dietary advice and information in the context of an education program that is tailored to the severity of their CKD and the need to modify salt, phosphate, potassium, and protein intake. Given these guidelines, up to date evidence of the benefits and harms of dietary management is needed to inform practice and policy.

In addition, patients, caregivers and health professionals consider the effects of dietary management as important and a priority treatment uncertainty in CKD (Manns 2014). When speaking about dietary changes, some patients experience dietary restrictions as an intense and unremitting burden (Palmer 2015a), while at the same time offering them greater self-efficacy in the management of their CKD. In general, patients value better understanding of the role of lifestyle management as a research priority (Tong 2015). Dietary management is therefore an important potential intervention for improving clinical outcomes in CKD that aligns with patient priorities. 


\section{O B JECTIVES}

This review evaluated the benefits and harms of dietary interventions among adults with CKD including people with end-stage kidney disease (ESKD) treated with dialysis or kidney transplantation.

\section{METHOD S}

\section{Criteria for considering studies for this review}

\section{Types of studies}

We included RCTs and quasi-RCTs (in which allocation to treatment was obtained by alternation, use of alternate medical records, date of birth, or other predictable methods) measuring the effect of dietary interventions in adults with CKD.

\section{Types of participants}

\section{Inclusion criteria}

Adults with any stage of CKD (any structural kidney or urine abnormality with or without reduced glomerular filtration rate below $60 \mathrm{~mL} / \mathrm{min} / 1.73 \mathrm{~m}^{2}$ as defined by the Kidney Disease: Improving Global Outcomes (KDIGO 2012)) including people with ESKD treated with dialysis, kidney transplantation or supportive care.

\section{Exclusion criteria}

Pregnant women and children younger than 18 years.

\section{Types of interventions}

\section{Inclusion criteria}

We evaluated the following dietary modifications (including dietary advice or lifestyle management) compared with any other dietary pattern or standard care (including lifestyle advice).

- Dietary patterns (e.g. DASH diet; Mediterranean diet, American Heart Association diet)

- Nutritional counselling and education about food-based dietary interventions

We included studies evaluating interventions for at least one month and studies in which concomitant non-randomised interventions such as antihypertensive medication, sodium restriction, or other co-interventions including supplements were used during the study period (e.g. specific blood pressure targets), providing that these interventions were administered to all treatment groups. We included studies of dietary modifications regardless of whether other dietary changes such as salt or phosphorus dietary intake were adjusted. We did not include differing levels of energy intake as interventions in the review.

\section{Exclusion criteria}

We excluded dietary interventions that were "single-nutrient" or nutrient-focused interventions (including supplementation). This included the following dietary management interventions.

- Dietary management of specific dietary factors including sodium, phosphorus, and protein (as these are evaluated in other Cochrane reviews (Fouque 2009; Jun 2012; Liu 2015; McMahon 2015)
- Probiotics, prebiotics, or synbiotics

- Implementation strategies for dietary or lifestyle management

\section{Types of outcome measures}

We categorised outcomes according to length of follow up $<6$ months and $\geq 6$ months). We extracted and analysed data for shorter ( $<6$ months) and longer ( $\geq 6$ months) term outcomes separately.

\section{Primary outcomes}

1. All-cause mortality

2. Major adverse cardiovascular events (as defined by study investigators)

3. Health-related quality of life (as defined and measured by investigators)

\section{Secondary outcomes}

1. Withdrawal from dietary intervention

2. Cause-specific death (cardiovascular mortality, sudden death, infection-related mortality)

3. Progression to ESKD (as defined by the investigators including estimated glomerular filtration rate below $15 \mathrm{~mL} / \mathrm{min} / 1.73$ $\mathrm{m}^{2}$ or requiring treatment with long-term dialysis or kidney transplantation)

4. Participant adherence to intervention

5. Myocardial infarction

6. Kidney function measures (creatinine clearance or estimated glomerular filtration rate, doubling of serum creatinine, serum creatinine)

7. Serum lipids (total cholesterol, low density lipoprotein (LDL) cholesterol, triglycerides)

8. Blood pressure

9. Blood glucose control (glycated haemoglobin; fasting plasma glucose)

10.Global measures of nutritional status (body mass index (BMI); body weight; waist circumference; subjective global assessment; malnutrition screening tool; mini nutritional assessment; skin-fold measurements; bioelectrical impedance analysis; albumin; prealbumin)

\section{Search methods for identification of studies}

\section{Electronic searches}

We searched the Cochrane Kidney and Transplant Specialised Register (up to 31 January 2017) through contact with the Information Specialist using search terms relevant to this review. The Cochrane Kidney and Transplant Specialised Register contains studies identified from several sources.

1. Monthly searches of the Cochrane Central Register of Controlled Trials (CENTRAL)

2. Weekly searches of MEDLINE OVID SP

3. Handsearching of kidney-related journals and the proceedings of major kidney conferences

4. Searching of the current year of EMBASE OVID SP

5. Weekly current awareness alerts for selected kidney and transplant journals 
6. Searches of the International Clinical Trials Register (ICTRP) Search Portal and ClinicalTrials.gov.

Studies contained in the Specialised Register are identified through search strategies for CENTRAL, MEDLINE, and EMBASE based on the scope of Cochrane Kidney and Transplant. Details of these strategies, as well as a list of handsearched journals, conference proceedings and current awareness alerts, are available in the Specialised Register section of information about Cochrane Kidney and Transplant.

See Appendix 1 for search terms used in strategies for this review.

\section{Searching other resources}

1. Reference lists of review articles, relevant studies and clinical practice guidelines.

2. Letters seeking information about unpublished or incomplete studies to investigators known to be involved in previous studies.

\section{Data collection and analysis}

\section{Selection of studies}

The search strategy was used to obtain titles and abstracts of studies that might have been relevant to the review. The titles and abstracts were screened independently by at least two authors (SP and JM), who discarded studies that were not eligible; however, studies and reviews that might have included relevant data or information on studies were retained initially. Two authors (SP and $\mathrm{JM}$ ) independently assessed retrieved abstracts and, if necessary the full text, of these studies to determine which studies satisfied the inclusion criteria. Any uncertainties about study eligibility were discussed between authors and if necessary with a third author (KC).

\section{Data extraction and management}

Data extraction was carried out independently by two authors using pre-specified standard data extraction forms. Studies reported in non-English language journals were electronically translated before assessment. Where more than one publication of one study exists, study reports were grouped together and the publication with the most complete data was used in the analyses. Where relevant outcomes are only published in earlier publications of the study, these data were used. Any discrepancy between published versions were evaluated and highlighted.

\section{Assessment of risk of bias in included studies}

The following reporting items were independently assessed by two authors (SP and JM) using the Cochrane risk of bias assessment tool (Higgins 2011) (see Appendix 2):

- Was there adequate sequence generation (selection bias)?

- Was allocation adequately concealed (selection bias)?

- Was knowledge of the allocated interventions adequately prevented during the study?

* Participants and personnel (performance bias)

* Outcome assessors (detection bias)

- Were incomplete outcome data adequately addressed (attrition bias)?
- Are reports of the study free of suggestion of selective outcome reporting (reporting bias)?

- Was the study apparently free of other problems that could put it at a risk of bias? These were pre-specified as: baseline imbalance, interim reporting, deviation from study protocol in a way that does not reflect clinical practice, pre-randomisation administration of an intervention that could enhance or diminish the effects of a subsequent randomised intervention, contamination, occurrence of 'null bias' due to interventions being insufficiently well delivered or overly wide inclusion criteria, selective reporting of subgroups, reporting of trial registration, reporting of funding source(s), publication as full journal report, and fraud.

\section{Measures of treatment effect}

For dichotomous outcomes (total and cause-specific mortality, myocardial infarction, progression to ESKD, doubling of serum creatinine, participant adherence, withdrawal from intervention), the treatment effects of dietary management were expressed as a risk ratio $(\mathrm{RR})$ together with $95 \%$ confidence intervals $(\mathrm{Cl})$. Where continuous scales of measurement are used to assess the effects of dietary management (health-related quality of life, blood pressure, lipids (total cholesterol, LDL cholesterol, triglycerides), kidney function (serum creatinine, creatinine clearance, glomerular filtration rate), body composition (weight, waist circumference, $\mathrm{BMI})$ ), the mean difference (MD) between treatment groups were used, or the standardised mean difference (SMD) if different measurement scales have been reported. A standardised mean difference of 0.2 indicated a small difference, 0.5 a moderate difference and 0.8 a large difference. We evaluated mean end of treatment values for continuous outcomes together with the reported standard deviation in meta-analyses for these continuous outcomes.

\section{Unit of analysis issues}

Studies with more than two interventions were evaluated in this review. We used recommended methods for data extraction and analysis described by the Cochrane Collaboration (Higgins 2011).

\section{Cross-over studies}

There were no cross-over studies included in this meta-analysis.

\section{Studies with more than two interventions}

Studies with multiple intervention groups were included. When a study was a 'multi-arm' study, and all treatment arms provided data for eligible interventions, the study was described and included in the systematic review. If there were adequate data from the study, then treatment arms relevant to the treatment comparisons of interest were included in applicable meta-analyses.

\section{Cluster randomised studies}

We planned to include information from cluster randomised studies. We planned to divide the effective sample size for each data point by a quantity called the design effect calculated as $1+(M-1)$ ICC, where $M$ was the average cluster size and ICC was the intra-cluster correlation coefficient. In this calculation, a common design effect was assumed across all intervention groups. The intra-cluster coefficient (ICC) is seldom available in published reports. We therefore planned to adopt a common approach to use external estimates obtained from similar studies. For dichotomous 
outcomes, we planned to divide the number of participants and the number experiencing the event by the design effect. For continuous endpoints only the sample size was planned to be divided by the design effect with means and standard deviations remaining unchanged.

\section{Dealing with missing data}

Any further information required from the original author was requested by electronic mail and any relevant information obtained in this manner was included in the review. Evaluation of important numerical data such as screened, randomised patients as well as intention-to-treat, as-treated and per-protocol population were carefully performed. Attrition rates, for example drop-outs, losses to follow-up and withdrawals were investigated. Issues of missing data and imputation methods (for example, last-observationcarried-forward) was critically appraised (Higgins 2011).

\section{Assessment of heterogeneity}

Statistical heterogeneity in treatment effects among studies was analysed using a $\mathrm{Chi}^{2}$ test on $\mathrm{N}-1$ degrees of freedom, with an alpha of 0.05 used for statistical significance and with the $\mathrm{I}^{2}$ test (Higgins 2003). We considered $I^{2}$ values of $25 \%, 50 \%$ and $75 \%$ as corresponding to low, medium and high levels of heterogeneity.

\section{Assessment of reporting biases}

There were insufficient data to generate funnel plots to assess for the potential existence of small study bias for the outcome of allcause mortality.

\section{Data synthesis}

We grouped studies by dietary modifications into similar interventions (e.g. counselling; Mediterranean; fruits and vegetables). Treatment estimates for the specified were summarised within groups of dietary modifications and treatment effects were summarised using random-effects meta-analysis. Effects were reported as the relative risk (RR) and 95\% confidence interval (CI) for binary outcomes and mean difference (MD) and 95\% $\mathrm{Cl}$ for continuous outcomes.

We summarised information for outcomes in which metaanalysis is not possible due to insufficient observations using narrative tables. Narrative outcome reporting included healthrelated quality of life domains described in the studies and nutrition assessments. The dietary interventions and associated implementation strategies were described using the "Better reporting of interventions: Template for Intervention Description and Replication (TIDieR) checklist and guide" (Hoffmann 2014) and tabulated in the review.

\section{Subgroup analysis and investigation of heterogeneity}

There were insufficient extractable data to conduct subgroup and univariate meta-regression analysis to explore the following variables as possible sources of heterogeneity: mean study age, mean proportion of men, energy intake, study-level mean blood pressure or cholesterol at baseline, proportion with diabetes, adequacy of allocation concealment, sample size, and duration of follow up ( $<12$ months versus $\geq 12$ months).

\section{Sensitivity analysis}

There were insufficient extractable data to perform the following sensitivity analyses in order to explore the influence of the following factors on effect size:

- Repeating the analysis excluding unpublished studies

- Repeating the analysis taking account of risk of bias, as specified above

- Repeating the analysis excluding any very long or large studies to establish how much they dominated the results

- Repeating the analysis excluding studies using the following filters: diagnostic criteria, language of publication, source of funding (industry versus other), and country.

\section{'Summary of findings' tables}

We presented the main results of the review in a 'Summary of findings' table for the outcomes of all-cause mortality, cardiovascular mortality, ESKD, and health-related quality of life. 'Summary of findings' tables present key information concerning the quality of the evidence, the magnitude of the effects of the interventions examined, and the sum of the available data for the main outcomes (Schunemann 2011a). The 'Summary of findings' tables also included an overall grading of the evidence related to each of the main outcomes using the GRADE (Grades of Recommendation, Assessment, Development and Evaluation) approach (GRADE 2008). The GRADE approach defines the quality of a body of evidence as the extent to which one can be confident that an estimate of effect or association is close to the true quantity of specific interest. The quality of a body of evidence involves consideration of within-trial risk of bias (methodological quality), directness of evidence, heterogeneity, precision of effect estimates and risk of publication bias (Schunemann 2011b).

\section{RES U LTS}

\section{Description of studies}

\section{Results of the search}

The electronic search strategy of the Cochrane Kidney and Transplant Specialised Register (31 January 2017) identified 824 records (Figure 1). After initial title and abstract screening, 754 records were excluded. The full-text of the remaining 70 records were evaluated. A further 47 records were excluded ( 21 were not in people with CKD, 25 were not evaluating dietary patterns, three were not randomised). 
Figure 1. Flow diagram of study selection

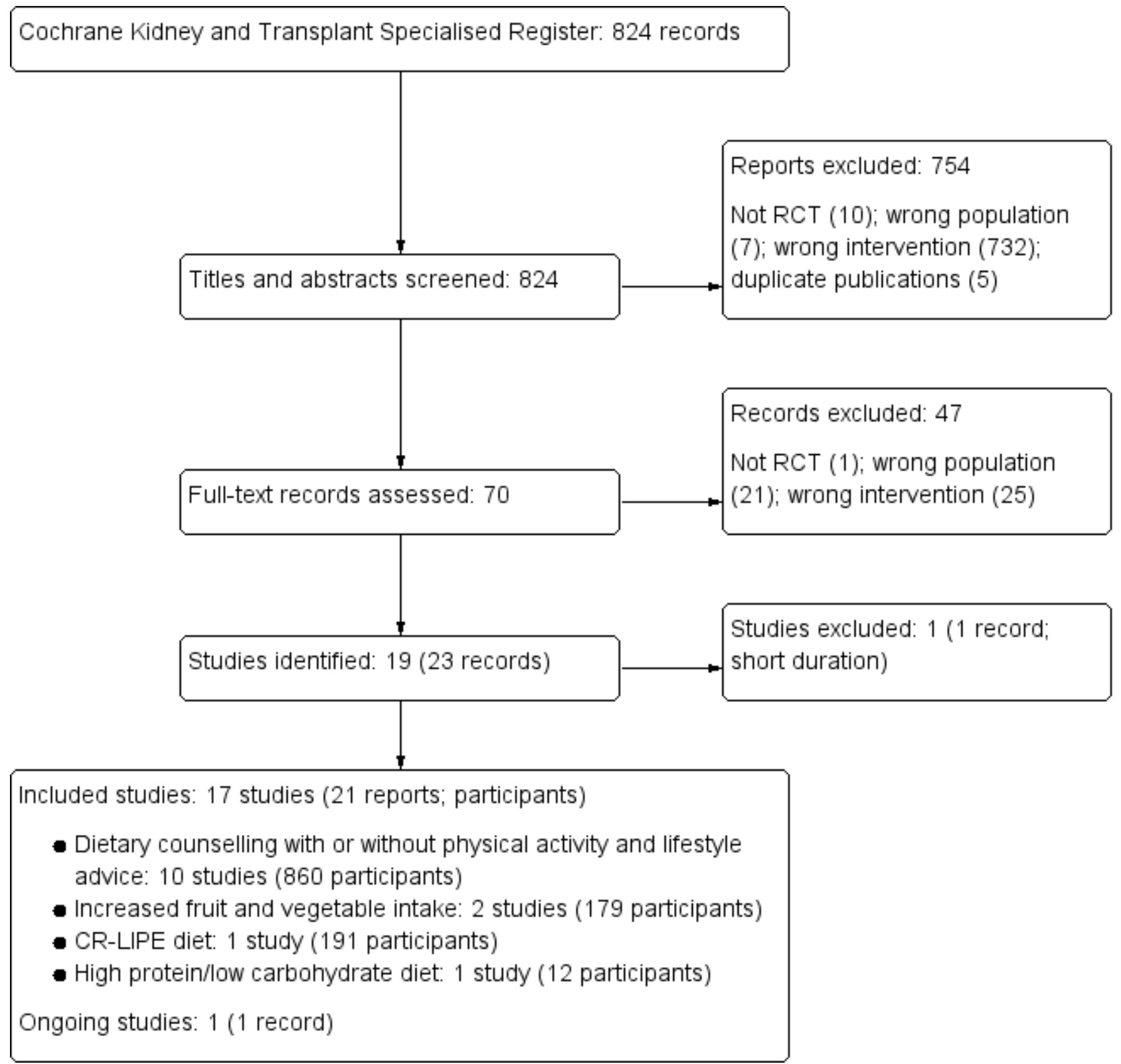

Seventeen studies (21 records) were included, one study was excluded, and one ongoing study was identified and will be assessed in a future update of this review.

\section{Included studies}

See Characteristics of included studies.

Overall, 17 studies reported in 21 publications involving 1639 people with CKD were eligible (Campbell 2008; Chanwikrai 2012; DIRECT Study 2013; Facchini 2003; Flesher 2011; Goraya 2013; Goraya 2014; Leon 2006; Mekki 2010; Orazio 2011; Riccio 2014; Stachowska 2005; Sutton 2007; Teng 2013; Tzvetanov 2014; Whittier 1985; Zhou 2011b). The study characteristics are summarised in Table 1. Studies were published between 2003 and 2014, with all but five (Facchini 2003; Leon 2006; Stachowska 2005; Sutton 2007; Whittier 1985) of the studies published since 2008.
Three studies enrolled 341 people treated with long-term dialysis (haemodialysis (1), peritoneal dialysis (2)), four studies enrolled 168 kidney transplant recipients, and 10 studies enrolled 1130 people with CKD stages 1 to 5 .

In the studies involving people with CKD, the average eGFR ranged between 21.6 and $75 \mathrm{~mL} / \mathrm{min} / 1.73 \mathrm{~m}^{2}$. Most participants with CKD had an eGFR $<60 \mathrm{~mL} / \mathrm{min} / 1.73 \mathrm{~m}^{2}$.The mean study eGFR ranged between 22.8 and $70 \mathrm{~mL} / \mathrm{min} / 1.73 \mathrm{~m}^{2}$. In kidney transplant recipients, the eGFR at baseline in the two studies reporting this was between 48 and $54 \mathrm{~mL} / \mathrm{min} / 1.73 \mathrm{~m}^{2}$.

Studies had generally small sample sizes (median 73 participants, range 12 to 318 patients). Participants were followed up for between one month and 3.9 years (median 12 months). 
Thirteen studies that reported funding received funding from governmental or healthcare organisations, and four studies did not report their funding source.

Studies were conducted in Algeria (Mekki 2010), Australia (Campbell 2008; Orazio 2011), Canada (Flesher 2011), China (Zhou 2011b), Israel (DIRECT Study 2013), Italy (Riccio 2014), Poland (Stachowska 2005), Taiwan (Teng 2013), Thailand (Chanwikrai 2012), the UK (Sutton 2007), and the USA (Facchini 2003; Goraya 2013; Goraya 2014; Leon 2006; Tzvetanov 2014; Whittier 1985).

The mean age in the included studies ranged between 41 years (Stachowska 2005) and 69.5 years (Campbell 2008). The mean BMI at baseline ranged between 22.8 and $38.6 \mathrm{~kg} / \mathrm{m}^{2}$ (median $28.5 \mathrm{~kg} /$ $\left.\mathrm{m}^{2}\right)$.

\section{Dietary interventions}

The methods for dietary implementation, tailoring, and measurement of adherence are provided in Table 2 and reported using a Template for Intervention Description and Replication (TIDieR) checklist (Hoffmann 2014).

Dietary interventions included dietary counselling with or without physical activity and lifestyle advice in 10 studies (860 participants) (Campbell 2008; Chanwikrai 2012; Flesher 2011; Leon 2006; Orazio 2011; Riccio 2014; Sutton 2007; Teng 2013; Tzvetanov 2014; Zhou 2011b), a Mediterranean diet in three studies (395 participants) (DIRECT Study 2013; Mekki 2010; Stachowska 2005), increased fruit and vegetable intake in two studies (179 participants) (Goraya 2013; Goraya 2014), a carbohydrate-restricted, low-iron available, polyphenol enriched (CR-LIPE) diet in Facchini 2003 (191 participants), and a high protein/low carbohydrate diet in Whittier 1985 (12 participants). A high fruit and vegetable intake was compared with oral bicarbonate supplementation in the setting of CKD. A Mediterranean diet was compared with a control diet, a low fat diet, or a low carbohydrate diet. In general, dietary modifications tended to include increased intake of fish and poultry, fruit and vegetables, olive oil, and nuts, and lower intake of carbohydrates, red meat, sodium, and sugars.

The aims of the dietary counselling studies were generally to assess whether dietary advice could improve nutritional status and body composition (Campbell 2008; Zhou 2011b), slow progression of CKD (Chanwikrai 2012; Flesher 2011), or decrease biochemical derangement in kidney disease (Riccio 2014; Teng 2013). Studies of dietary patterns were primarily aimed at assessing effects of dietary intake on kidney function (DIRECT Study 2013; Facchini 2003; Goraya 2013; Goraya 2014) or dyslipidaemia (Mekki 2010). Among people treated with dialysis, the interventions were aimed at increasing serum albumin levels (Leon 2006), supporting adjusted energy intake (Sutton 2007), and improving under nutrition (Zhou 2011b). Dietary interventions for transplant recipients aimed to modify cardiovascular risk factors (Orazio 2011; Stachowska 2005), provide lifestyle advice including nutrition guidance (Tzvetanov 2014), or reduce cushingoid side-effects.

Two studies reported three treatment groups. In DIRECT Study 2013, a calorie-restricted Mediterranean diet was compared with a calorie-restricted low-fat diet or calorie-unrestricted lowcarbohydrate diet. In Goraya 2014, increased fruit and vegetable intake was compared with oral bicarbonate supplementation and standard care.

\section{Excluded studies}

The one study which meet our population and intervention criteria was excluded as it was only for a short duration (10 days) (Parillo 1988).

\section{Risk of bias in included studies}

See Figure 2; Figure 3 for summary of 'Risk of bias' assessments.

\section{Figure 2. Risk of bias graph: review authors' judgements about each risk of bias item presented as percentages} across all included studies.

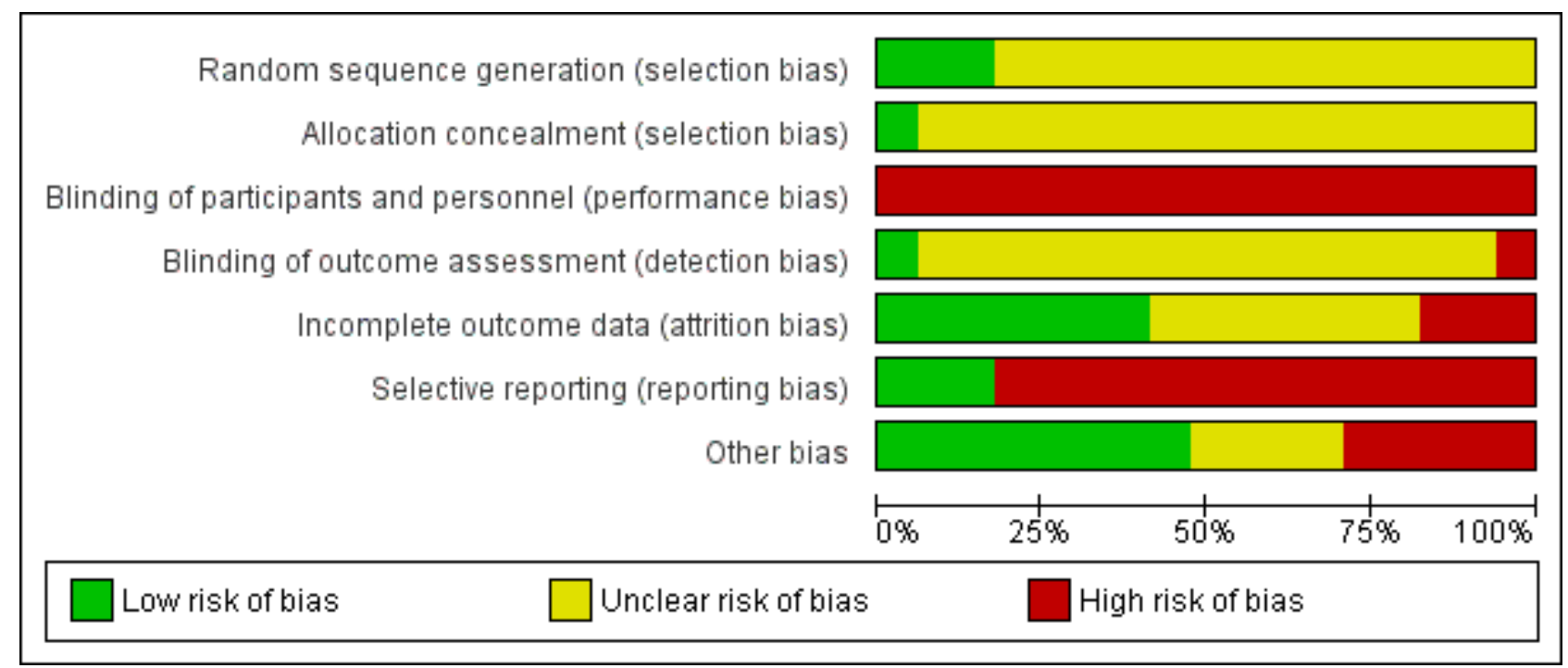


Figure 3. Risk of bias summary: review authors' judgements about each risk of bias item for each included study.

\begin{tabular}{|c|c|c|c|c|c|c|c|}
\hline & 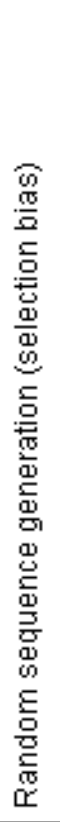 & 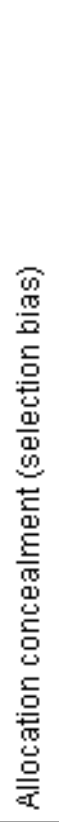 & 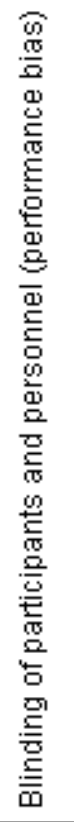 & 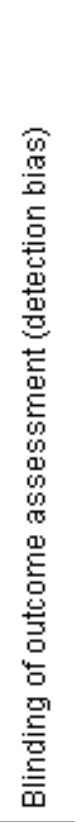 & 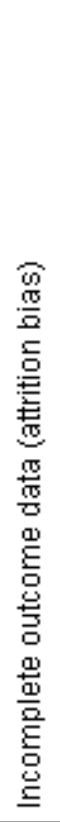 & 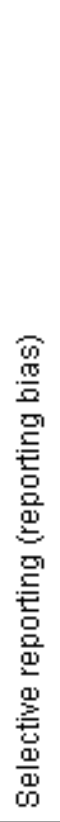 & 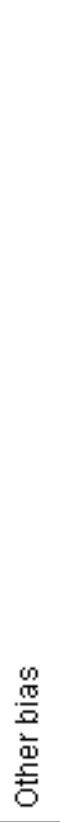 \\
\hline Campbell 2008 & $\odot$ & $\odot$ & $\odot$ & ? & $\odot$ & $\oplus$ & $\oplus$ \\
\hline Chanwikrai 2012 & $?$ & $?$ & - & $?$ & + & - & - \\
\hline DIRECT Study 2013 & $?$ & ? & - & $\odot$ & + & $\odot$ & $\odot$ \\
\hline Facchini 2003 & $?$ & ? & - & $?$ & + & + & $?$ \\
\hline Flesher 2011 & ? & ? & - & ? & + & + & + \\
\hline Goraya 2013 & ? & ? & 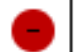 & ? & ? & - & + \\
\hline Goraya 2014 & ? & ? & ค & ? & ? & - & + \\
\hline Leon 2006 & + & ? & - & ? & $\Theta$ & - & $\odot$ \\
\hline Mekki 2010 & $?$ & $?$ & - & ? & $?$ & - & + \\
\hline Orazio 2011 & $?$ & $?$ & 0 & $?$ & $?$ & - & + \\
\hline Riccio 2014 & ? & $?$ & 0 & ? & $?$ & - & - \\
\hline Stachowska 2005 & ? & ? & & ? & ? & - & - \\
\hline Sutton 2007 & $\odot$ & ? & 0 & ? & $\odot$ & - & $?$ \\
\hline Teng 2013 & ? & ? & $\Theta$ & $?$ & + & - & + \\
\hline Tzuetanov 2014 & $?$ & ? & 0 & ? & - & - & $?$ \\
\hline Whittier 1985 & $?$ & ? & 0 & ? & ? & - & + \\
\hline Zhou $2011 \mathrm{~b}$ & ? & ? & - & - & + & - & ? \\
\hline
\end{tabular}


Reporting of details of study methodology was incomplete for most studies. The summary risks of bias are shown in Figure 2 and risk of bias in each individual study is shown in Figure 3.

\section{Allocation}

\section{Random sequence generation}

Three studies reported adequate (low risk) random sequence generation (Campbell 2008; Leon 2006; Sutton 2007). The risk of bias from random sequence generation methods was unclear in the remaining 14 studies.

\section{Allocation concealment}

Only Campbell 2008 was judged to have adequate allocation concealment (low risk). Risks from allocation concealment was unclear in the remaining 16 studies.

\section{Blinding}

\section{Performance bias}

Dues to the nature of the interventions, performance bias was judged as high risk in all 17 studies.

\section{Detection bias}

Detection bias was judged to be low risk in DIRECT Study 2013 and high in Zhou 2011b. Risk of detection bias was unclear in the remaining 15 studies.

\section{Incomplete outcome data}

Attrition bias was low risk in seven studies (Campbell 2008; Chanwikrai 2012; DIRECT Study 2013; Facchini 2003; Flesher 2011; Teng 2013; Zhou 2011b) and high risk in three studies (Leon 2006; Sutton 2007; Tzvetanov 2014). Risks from attrition bias were unclear in the remaining seven studies.

\section{Selective reporting}

Three studies were at low risk of reporting bias (Campbell 2008; Facchini 2003; Flesher 2011), and the remaining 14 studies were at high risk of reporting bias.

\section{Other potential sources of bias}

Eight studies were judged to be at low risk of other potential biases (Campbell 2008; Flesher 2011; Goraya 2013; Goraya 2014; Mekki 2010; Orazio 2011; Teng 2013; Whittier 1985); five studies were judged to be high risk of bias (Chanwikrai 2012; DIRECT Study 2013; Leon 2006; Riccio 2014; Stachowska 2005), and risks of bias were unclear in four studies (Facchini 2003; Sutton 2007; Tzvetanov 2014; Zhou 2011b).

\section{Effects of interventions}

See: Summary of findings for the main comparison Dietary modifications (counselling or dietary change) versus control for chronic kidney disease (CKD)

Data for health-related quality of life are shown in Table 3. Adverse event data are reported in Table 4. Adverse events were rarely reported.

\section{Primary outcomes}

No included studies were designed to examine effects of dietary interventions on all-cause mortality or major cardiovascular events. The confidence in the results for these outcomes was very low.

\section{All-cause mortality}

Five studies (Campbell 2008; Facchini 2003; Flesher 2011; Leon 2006; Sutton 2007) reported the number of deaths. Of these, four studies (Campbell 2008; Flesher 2011; Leon 2006; Sutton 2007) reported deaths as part of the information provided about participant recruitment or attrition from study follow-up which lasted between 12 weeks and 12 months. Dietary counselling had uncertain effects on all-cause mortality (Analysis 1.1.1 (4 studies, 371 participants): $\mathrm{RR} 1.59,95 \% \mathrm{Cl} 0.60$ to $4.21 ; 12=0 \%$ ).

In one study comparing a low-iron-available, polyphenol enriched carbohydrate-restricted (CR-LIPE) diet with control over 3.9 years (Facchini 2003), mortality was reported as a patient outcome. A CRLIPE diet had uncertain effects on all-cause mortality compared with standard care (Analysis 1.1.2 (1 study, 170 participants): RR $0.50,95 \% \mathrm{Cl} 0.22$ to 1.12 ). The confidence in the evidence for allcause mortality was very low (Summary of findings for the main comparison).

\section{Major adverse cardiovascular events}

Campbell 2008 death from cardiovascular causes was described by investigators when reporting study loss to follow-up during the 12 month study. Dietary counselling had very uncertain effects on cardiovascular mortality (Analysis 1.2.1 (1 study, 62 participants): RR $6.58,95 \% \mathrm{Cl} 0.35$ to 122.21 ). The confidence in the evidence for cardiovascular events was very low (Summary of findings for the main comparison).

\section{Health-related quality of life}

Only six studies included quality of life measures (Table 3). Of these, four studies used the Kidney Disease Quality of Life questionnaire and/or the Short Form-36 (Campbell 2008; Leon 2006; Tzvetanov 2014; Zhou 2011b). In two studies (Tzvetanov 2014; Zhou 2011b), dietary counselling was associated with a higher score on the SF-36 questionnaire than standard care (Analysis 1.3.1 (2 studies, 119 participants): MD $11.46,95 \% \mathrm{Cl} 7.73$ to 15.18 ; $\left.\left.\right|^{2}=0 \%\right)$. The confidence in the evidence for health-related quality of life was low (Summary of findings for the main comparison).

\section{Secondary outcomes}

\section{End-stage kidney disease}

No included studies were designed to examine ESKD or risks of doubling of serum creatinine. The confidence in the results for ESKD was very low. Two studies reported the number of participants experiencing ESKD (Campbell 2008; Facchini 2003). In one of these studies comparing dietary counselling with standard care, the number of people starting dialysis was reported as part of participant progression in the 12-week study (Campbell 2008). In one study, a CR-LIPE diet had uncertain effects on ESKD compared with standard care. In the two studies combined, dietary interventions did not have statistically significant effect on risks of ESKD ((Analysis 1.4 (2 studies, 232 participants): RR 0.53, 95\% Cl 
0.26 to $\left.1.07 ;\left.\right|^{2}=0 \%\right)$. The confidence in the evidence for ESKD was very low (Summary of findings for the main comparison).

\section{Doubling of serum creatinine}

Facchini 2003 reported that a CR-LIPE diet was associated with lower risks of doubling of serum creatinine ((Analysis 1.5 (1 study, 170 participants): $\mathrm{RR} 0.53,95 \% \mathrm{Cl} 0.33$ to 0.86 ).

\section{Employment}

Dietary counselling had uncertain effects on employment during a single 12 month study involving recipients of a kidney transplant (Analysis 1.6 (1 study, 17 participants): RR $6.22,95 \% \mathrm{Cl} 0.96$ to 40.22).

\section{Dietary adherence}

Dietary counselling had uncertain effects on dietary adherence compared with standard care, in a single study (Analysis 1.7 ( 1 study 54 participants): $\mathrm{RR} 1.58,95 \% \mathrm{Cl} 0.97$ to 2.58 ).

\section{Worsening nutrition}

In two studies, the proportion of participants with worsening nutritional status was measured using subjective global assessment (SGA) (Campbell 2008; Leon 2006). Compared with usual care, dietary counselling had uncertain effects on nutritional status as measured by SGA (Analysis 1.8.1 (2 studies, 230 participants): RR $0.40,95 \% \mathrm{Cl} 0.05$ to $\left.3.37 ;\left.\right|^{2}=57 \%\right)$.

\section{Kidney function}

eGFR

Dietary intervention was associated with a higher eGFR (Analysis 1.9 (5 studies, 219 participants): SMD 1.08; 95\% Cl 0.20 to 1.97 ; $12=88 \%)$ than standard care, although there was very marked heterogeneity in treatment effects between the four studies evaluating dietary counselling and this may have been due to the different strategies used in participant counselling.

Fruits and vegetables had uncertain effects on the eGFR compared with oral bicarbonate supplementation (Analysis 3.1 (2 studies, 143 participants); $\mathrm{MD} 0.84 \mathrm{~mL} / \mathrm{min} / 1.73 \mathrm{~m}^{2}, 95 \% \mathrm{Cl}-0.84$ to $2.53 ; \mathrm{I}^{2}=$ $0 \%)$.

\section{Serum creatinine}

Dietary interventions had uncertain effects on serum creatinine when compared to control (Analysis 1.10 (3 studies 112 participants): $\mathrm{MD} 0.83 \mu \mathrm{mol} / \mathrm{L}, 95 \% \mathrm{Cl}-16.57$ to 18.23 ; $\left.\right|^{2}=0 \%$ ).

In Goraya 2013, fruits and vegetables had very uncertain effects on serum creatinine compared with oral bicarbonate supplementation (Analysis 3.2 (1 study, 71 participants): MD -9.00 $\mu \mathrm{mol} / \mathrm{L}, 95 \% \mathrm{Cl}-39.11$ to 21.11 ).

\section{Blood pressure}

\section{Systolic blood pressure}

Dietary interventions lowered systolic blood pressure compared with standard care (Analysis 1.11 (3 studies, 167 participants): MD $-9.26 \mathrm{~mm} \mathrm{Hg}, 95 \% \mathrm{Cl}-13.48$ to $\left.-5.04 ; \mathrm{I}^{2}=80 \%\right)$. There was heterogeneity in the effects between the two different dietary approaches $\left(1^{2}=88.7 \%\right)$.
Fruits and vegetables lowered systolic blood pressure compared to oral bicarbonate supplementation (Analysis 3.3 (2 studies, 143 participants): $\mathrm{MD}-5.81 \mathrm{~mm} \mathrm{Hg}, 95 \% \mathrm{Cl}-8.84$ to -2.77 ) although there was high heterogeneity between studies $\left({ }^{2}=79 \%\right)$.

\section{Diastolic blood pressure}

Dietary counselling lowered diastolic blood pressure compared with standard care (Analysis 1.12 (2 studies, 95 participants): MD $-8.95 \mathrm{~mm} \mathrm{Hg}, 95 \% \mathrm{Cl}-10.69$ to $-7.21 ; \mathrm{I}^{2}=0 \%$ )

\section{Energy intake}

Different dietary interventions had statistically heterogeneous effects on energy intake and therefore the results of all available dietary approaches compared with standard care were not combined within a single analysis.

Dietary counselling had uncertain effects on energy intake compared to standard care (Analysis 1.13.1 (4 studies, 340 participants); SMD $1.54,95 \% \mathrm{Cl}-0.87$ to 3.95$)$. There was very high heterogeneity in this analysis ( $\left.1^{2}=99 \%\right)$ likely due to the differing counselling approaches in the included studies.

A Mediterranean diet was associated with higher energy intake than standard care in Mekki 2010 (Analysis 1.13.2 (1 study, 40 participants): SMD 1.86, 95\% Cl 1.11-2.61).

A high nitrogen and low carbohydrate diet had uncertain effects on energy intake in Whittier 1985 (Analysis 1.13 (1 study, 12 participants): SMD $-0.65,95 \% \mathrm{Cl}-1.82$ to 0.53 ).

\section{Body weight, BMI, waist circumference, waist-to-hip ratio and arm circumference}

\section{Body weight}

Dietary interventions had uncertain effects on body weight compared with control (Analysis 1.14 (6 studies, 454 participants): MD $-0.44 \mathrm{~kg}, 95 \% \mathrm{Cl}-1.46$ to $\left.0.58 ; \mathrm{I}^{2}=15 \%\right)$.

A higher fruit and vegetable intake was associated with a lower body weight than oral bicarbonate supplementation (Analysis 3.4 (2 studies, 143 participants):; MD $-5.09 \mathrm{~kg}, 95 \% \mathrm{Cl}-7.73$ to -2.44 ; $\left.\right|^{2}$ $=56 \%)$.

\section{BMI}

Dietary interventions had uncertain effects on BMI compared with control (Analysis 1.15 (2 studies, 119 participants): MD $-1.70 \mathrm{~kg} / \mathrm{m}^{2}$, $95 \% \mathrm{Cl}-5.23$ to $\left.1.82 ;\left.\right|^{2}=14 \%\right)$.

\section{Waist-to-hip ratio, waist circumference, and arm circumference}

In Orazio 2011, dietary interventions had uncertain effects on waist-to-hip ratio compared with control (Analysis 1.16 (1 study, 82 participants): MD $-1.05,95 \% \mathrm{Cl}-5.92$ to 3.82 ). In the same study, dietary interventions had uncertain effects on the waist circumference (Analysis 1.17 ( 1 study, 82 participants): MD $-0.46 \mathrm{~cm}$, $95 \% \mathrm{Cl}-2.05$ to 1.13$)$.

Dietary interventions had uncertain effects on arm circumference compared with control (Analysis 1.18 (2 studies, 149 participants): MD $0.37 \mathrm{~cm}, 95 \% \mathrm{Cl}-0.39$ to $1.12 ; \mathrm{I}^{2}=0 \%$ ). 


\section{Serum albumin}

Dietary interventions increased serum albumin levels compared with control (Analysis 1.19 (6 studies, 541 participants): MD $0.16 \mathrm{~g} /$ dL, $95 \% \mathrm{Cl} 0.07$ to $0.24 ; \mathrm{I}^{2}=26 \%$ ).

\section{Serum LDL cholesterol}

In Mekki 2010, a Mediterranean diet lowered serum LDL cholesterol levels compared with a control diet (Analysis 1.20.1 (1 study, 40 participants): $\mathrm{MD}-1.00 \mathrm{mmol} / \mathrm{L}, 95 \% \mathrm{Cl}-1.56$ to -0.44$)$.

In Facchini 2003, a CR-LIPE diet had uncertain effects on serum LDL cholesterol levels compared with a control diet (Analysis 1.20.2 (1 study, 148 participants): MD $0.21 \mathrm{mmol} / \mathrm{L}, 95 \% \mathrm{Cl}-0.38$ to 0.81 ).

In Stachowska 2005, a Mediterranean diet lowered serum LDL cholesterol levels compared with a low fat diet (Analysis 2.1 (1 study, 38 participants): MD $-0.60 \mathrm{mmol} / \mathrm{L}, 95 \% \mathrm{Cl}-1.15$ to -0.05$)$.

\section{Investigation of publication bias, sub-group analyses and sensitivity analyses}

Investigation of publication bias, sub-group analyses and sensitivity analyses were not possible due to a lack of data observations. In particular there were insufficient data observations to test whether effects of dietary interventions were modified by stage of kidney disease.

\section{DISCUSSION}

\section{Summary of main results}

This review summarises 17 studies of dietary interventions involving 1639 people with CKD that took place in a wide variety of global regions and health systems. Dietary interventions were evaluated for a median of 12 months. Dietary interventions were counselling, or a dietary pattern (Mediterranean; low fat; low carbohydrate; high fruit and vegetable; carbohydrate-restricted, low-iron available, polyphenol-enriched; low carbohydrate-high nitrogen) compared with standard care, low protein intake, low fat or low carbohydrate intake, or oral bicarbonate supplementation. The studies included people with stages 1-5 CKD, kidney transplant recipients, and people with ESKD requiring dialysis. There was considerable heterogeneity in dietary interventions and their implementation, together with differences in tailoring of dietary management to individual requirements and methods to support adherence. Risks of bias in the included studies were often high or unclear, and these risks combined with imprecision in effect estimates led to low or very low confidence in the results.

Studies were not designed to assess dietary effects on risks of death or cardiovascular events. As a result there was considerable uncertainty about the effects of dietary approaches on these outcomes including risks of myocardial infarction or stroke. This finding is particularly relevant as many people with CKD will die from cardiovascular causes before requiring treatment with dialysis or kidney transplantation.

Dietary effects on health-related quality of life were infrequently reported and were documented using different tools, limiting the ability of studies to be combined. In low quality evidence, dietary interventions may have clinically-important increases in the SF-36 quality of life score. There was evidence that dietary modification impacted risks of ESKD, although dietary interventions may increase GFR compared with standard care. Dietary interventions lowered systolic and diastolic blood pressure by nearly $10 \mathrm{~mm} \mathrm{Hg}$ on average and increased serum albumin levels.

Overall, these data suggest that current evidence for dietary interventions in the setting of CKD is of very low quality and insufficient to guide clinical practice. Possible beneficial effects of dietary modifications on risk factors for disease in this review, the association of healthy eating patterns with lower mortality in nonrandomised studies (Chen 2016; Gutierrez 2014; Muntner 2013), and the priority placed on dietary restrictions in research (Tong 2015a) suggest dietary interventions remain an important research and clinical uncertainty in the setting of kidney disease.

\section{Overall completeness and applicability of evidence}

The strengths of this review comprehensive systematic searching for eligible studies, rigid inclusion criteria for RCTs, and data extraction and analysis by two independent investigators. We aimed to evaluate the effectiveness of dietary modification for range of food groups for people with CKD. This review included a small number of studies with heterogeneous interventions and implementation strategies. We could not robustly assess the effect of dietary pattern on endpoints such as mortality or cardiovascular events in people with CKD as there were few studies of sufficient size or duration to examine these outcomes. Despite preliminary evidence for improved blood pressure and serum cholesterol with some dietary patterns, evidence for the longerterm effects of dietary pattern on patient-level outcomes remains to be determined. There was a lack of consistency in estimating health-related quality of life among the available studies. Given the patients report dietary requirements and restrictions as a sometimes intense burden (Palmer 2015a), this aspect of dietary interventions remains important for future exploration. Reporting of health-related quality of life using tools validated for CKD would be helpful in future research studies.

\section{Quality of the evidence}

We assessed the quality of study evidence using standard risks of bias domains within the Cochrane tool together with GRADE methodology. Confidence in evidence for all-cause mortality, major cardiovascular events and health-related quality of life was very low or could not be estimated, meaning future studies might offer different results. No study had low risk methods for allocation concealment and none of the participants or study investigators was masked to treatment allocation. We downgraded for the possibility of publication bias due to the very low numbers of data observations for each outcome, precluding formal testing.

Data summary was also difficult due to the variable methods of reporting in the individual studies. Particularly relevant was the heterogeneous manner of reporting GFR and serum creatinine concentrations. Some studies did not report an estimate of variance (SE or SD) and some provided data in descriptive or figure format only.

\section{Potential biases in the review process}

Potential biases in this review relate to the data availability in the individual studies. First, there was heterogeneity in treatment interventions and comparisons; due to the small number of data observations, robust statistical estimates of heterogeneity could not be estimated. Second, we could not assess for potential 
reporting bias due to the small number of studies in the review. Third, while most participants had moderate CKD (stage 3 or 4), there was wide variation in the definition of kidney disease for inclusion in eligible studies. Fourth, studies were frequently at high risks of bias, but poorer quality studies could not be excluded from sensitivity analyses due to the limited number of data observations. Fifth, the treatment endpoints were principally surrogate markers of health (blood pressure, serum cholesterol, serum albumin) and the effects of dietary interventions on longer term outcomes remains uncertain. Sixth, adverse event reporting in the available studies was infrequent and inconsistent. Finally, selective outcome reporting was a limitation across the included studies.

\section{Agreements and disagreements with other studies or reviews}

A recently published Cochrane review (McMahon 2015) evaluated salt restriction among patients with CKD. While the intervention decreased blood pressure, as in this review there were insufficient data available to assess the impact of salt restriction on all-cause mortality or cardiovascular mortality. Similarly, in a Cochrane review of dietary interventions for mineral and bone disorder in CKD, there was low quality evidence that calcium enriched bread might influence biochemical parameters, and data were insufficient to identify treatment effects on clinical outcomes including cardiovascular mortality and fracture (Liu 2015). In a Cochrane review of low protein diets among people with CKD, a delay in progression of CKD was observed with a low protein intake (Fouque 2009). A recent meta-analysis of eight non-randomised of eating patterns among 15,285 people with CKD, healthy eating was associated with lower risks of all-cause mortality (RR 0.73 , $95 \% \mathrm{Cl} 0.63$ to 0.83 ), but no effect on ESKD was detected (personal communication). The possible reasons for differences between the findings of that review and the present meta-analysis could include the non-randomised nature of the data, with the possibility of residual confounding accounting for the results, or a larger sample size providing greater statistical power to observe differences between treatment groups. A non-randomised study conducted in the general population reported a dietary pattern rich in whole grains, fruit, and low-fat dairy foods was associated with lower urinary albumin to creatinine ratio (Nettleton 2008). Albumin to creatinine ratio is used as a proxy marker for possibility of development of kidney disease in the general population and is also suggestive of increased risk of cardiovascular disease in patients with diabetes and hypertension. The finding that a study in this review showing a diet pattern with lower red meat and carbohydrates and higher olive oil content was associated with lower risks of kidney failure suggests larger studies evaluating dietary patterns on progression of CKD are clinically relevant.

\section{AUTHORS' CONCLUSIONS}

\section{Implications for practice}

Overall, these data suggest that current evidence for dietary interventions in the setting of CKD is of very low quality and insufficient to guide clinical practice. Possible beneficial effects of dietary interventions include clinically-important increases in health-related quality of life, lower blood pressure and serum LDL cholesterol levels and higher kidney function and serum albumin levels. These preliminary findings represent potential mechanisms for benefit of dietary modifications in larger studies, but the longer term impact of dietary changes need to be examined.
Due to variation in dietary implementation and content, the range of clinical settings in the studies, and the lack of evidence for clinical outcomes, specific dietary recommendations or counselling cannot be currently recommended in the care of CKD or people treated with dialysis or a kidney transplant. As patients report dietary changes to be frequently confronting and intrusive and challenging to implement, patient input into future study design could strengthen the quality and acceptability of tested interventions. Not all areas of the world have health systems where dietitians are able to provide patient-centred care or patients have access to food types used in the studies in this review, and food availability and health service funding might be important barriers to future clinical studies.

\section{Implications for research}

Questions remain about the impact of dietary patterns on longterm clinical outcomes in the setting of CKD. Dietary restrictions are a priority uncertainty in CKD for patients and clinicians. This review highlights potential intermediary mechanisms (lowering blood pressure or serum cholesterol) through which dietary counselling or specific dietary patterns might act to benefit long-term health outcomes among people with CKD.

Given existing non-randomised studies suggest benefits of healthy, plant-based dietary patterns on lowering mortality in CKD (Chen 2016; Gutierrez 2014), and large RCTs show the Mediterranean diet lowers cardiovascular complications among people at risk of cardiovascular disease (Estruch 2013), further research is needed to evaluate the impact of dietary patterns on hard clinical outcomes including mortality and cardiovascular endpoints in CKD. Qualitative data are available about the impact of dietary restrictions on patient well-being (Palmer 2015a) that might be considered when designing dietary strategies and their implementation. Given that existing studies have generally small sample sizes and insufficient power to determine effects on mortality and cardiovascular events, consideration of a pragmatic study design to ensure efficient participant recruitment, such as a registry-trial design, might assist with study feasibility and cost.

Future research should pay specific attention to outcomes that have been relatively under-researched, but are important causes of significant morbidity. Due to the considerably higher risk of death and cardiovascular events compared to ESKD, future studies should be powered to assess dietary effects on these outcomes. We plan to add these to the review outcomes in future review updates if they become available. There were no studies incorporating economic analyses; we suggest future studies should include analyses of the relative costs and benefits of dietary management. Dietary studies involving participants in resource-constrained settings should be considered.

Given the variation in outcome measures routinely collected and reported in nephrology studies including studies in the present review, a core (minimum) data set, such as that being generated by the SONG collaboration (Tong 2015b), together with a validated measure of health-related quality of life would facilitate development of clinically-relevant studies and useful meta-analyses of dietary interventions.

Future studies in this area would benefit from drawing on a framework for studies of complex interventions, which explicitly requires theoretical modelling between processes and outcomes in 
the pre-trial stage, and a process evaluation of the study (Anderson 2008). All studies should provide greater description of intervention and standard models of care being assessed (Hoffmann 2014) and include process evaluations of how they are being implemented (Moore 2014), using reporting guidelines for complex interventions.

\section{ACKNOWLEDGEMENTS}

We wish to thank Katrina Soroka, research assistant at the University of Otago Christchurch in 2013, for her assistance with our protocol. We also wish to thank the referees for very helpful advice and assistance in the review's scope and content. We thank the personnel at the Cochrane Kidney and Transplant Group editorial office for tireless work including with this review. We thank Elaine Beller (Deputy Co-ordinating Editor) and Elisabeth Hodson (Cochrane editor) for overseeing the review process. Suetonia Palmer wishes to acknowledge generous funding from the Royal Society of New Zealand Rutherford Discovery Fellowship programme for salary and research support during the preparation of the protocol and full review. 


\section{R E F E R E N C E S}

\section{References to studies included in this review}

Campbell 2008 \{published data only\}

Campbell KL, Ash S, Bauer JD. The impact of nutrition intervention on quality of life in pre-dialysis chronic kidney disease patients. Clinical Nutrition 2008;27(4):537-44. [MEDLINE: 18584924]

* Campbell KL, Ash S, Davies PS, Bauer JD. Randomized controlled trial of nutritional counseling on body composition and dietary intake in severe CKD. American Journal of Kidney Diseases 2008;51(5):748-58. [MEDLINE: 18436085]

Chanwikrai 2012 \{published data only\}

* Chanwikrai Y, Satirapod B. A randomized controlled trial of dietary and lifestyle modification based on the empowerment approach among chronic kidney disease patients [abstract no:311]. Kidney Research \& Clinical Practice 2012;31(2):A95.

\section{DIRECT Study 2013 \{published data only\}}

Shai I. The effect of low-carb, Mediterranean and low-fat diets on renal function; a 2-year dietary intervention randomized controlled trial (DIRECT) [abstract]. Obesity Facts 2012;5(Suppl 1):19. [EMBASE: 70781690]

* Tirosh A, Golan R, Harman-Boehm I, Henkin Y, Schwarzfuchs D, Rudich A, et al. Renal function following three distinct weight loss dietary strategies during 2 years of a randomized controlled trial. Diabetes Care 2013;36(8):2225-32. [MEDLINE: 23690533]

\section{Facchini 2003 \{published data only\}}

* Facchini FS, Saylor KL. A low-iron-available, polyphenolenriched, carbohydrate-restricted diet to slow progression of diabetic nephropathy. Diabetes 2003;52(5):1204-9. [MEDLINE: 12716753]

\section{Flesher 2011 \{published data only\}}

* Flesher M, Woo P, Chiu A, Charlebois A, Warburton DE, Leslie B. Self-management and biomedical outcomes of a cooking, and exercise program for patients with chronic kidney disease. Journal of Renal Nutrition 2011;21(2):188-95. [MEDLINE: 20650652]

\section{Goraya 2013 \{published data only\}}

* Goraya N, Simoni J, Jo CH, Wesson DE. A comparison of treating metabolic acidosis in CKD stage 4 hypertensive kidney disease with fruits and vegetables or sodium bicarbonate. Clinical Journal of the American Society of Nephrology: CJASN 2013;8(3):371-81. [MEDLINE: 23393104]

\section{Goraya 2014 \{published data only\}}

* Goraya N, Simoni J, Jo CH, Wesson DE. Treatment of metabolic acidosis in patients with stage 3 chronic kidney disease with fruits and vegetables or oral bicarbonate reduces urine angiotensinogen and preserves glomerular filtration rate. Kidney International 2014;86(5):1031-8. [MEDLINE: 24694986]
Leon 2006 \{published data only\}

* Leon JB, Albert JM, Gilchrist G, Kushner I, Lerner E, Mach S, et al. Improving albumin levels among hemodialysis patients: a community-based randomized controlled trial. American Journal of Kidney Diseases 2006;48(1):28-36. [MEDLINE: 16797384]

Mekki 2010 \{published data only\}

* Mekki K, Bouzidi-bekada N, Kaddous A, Bouchenak M. Mediterranean diet improves dyslipidemia and biomarkers in chronic renal failure patients. Food \& Function 2010;1 (1):110-5. [MEDLINE: 21776461]

\section{Orazio 2011 \{published data only\}}

* Orazio LK, Isbel NM, Armstrong KA, Tarnarskyj J, Johnson DW, Hale RE, et al. Evaluation of dietetic advice for modification of cardiovascular disease risk factors in renal transplant recipients. Journal of Renal Nutrition 2011;21(6):462-71. [MEDLINE: 21454091]

Riccio 2014 \{published data only\}

* Riccio E, Sabbatini M, Bellizzi V, Pisani A. Effects of the 6point diet on the metabolic control, the compliance and the nutritional status of CKD patients stage 3B-5 [abstract no: MP248]. Nephrology Dialysis Transplantation 2014;29(Suppl 3):iii410-1. [EMBASE: 71492651]

\section{Stachowska 2005 \{published data only\}}

Stachowska E, Gutowska I, Strzelczak A, Wesolowska T, Safranow K, Ciechanowski K, et al. The use of neural networks in evaluation of the direction and dynamics of changes in lipid parameters in kidney transplant patients on the Mediterranean diet.[Erratum appears in J Ren Nutr. 2006 Jul;16(3):290 Note: Ciechanowski, Kazimierz [added]]. Journal of Renal Nutrition 2006;16(2):150-9. [MEDLINE: 16567272]

Stachowska E, Wesolowska T, Olszewska M, Safranow K, Millo B, Domanski $\mathrm{L}$, et al. Elements of Mediterranean diet improve oxidative status in blood of kidney graft recipients. British Journal of Nutrition 2005;93(3):345-52. [MEDLINE: 15877874]

Stachowska E, Wesolowska T, Safranow K, Domanski L, Rac M, Dziedziejko V, et al. Simple dietary interventions reduce the risk factors of atherosclerosis in renal graft recipients. Journal of Renal Nutrition 2005;15(3):291-7. [MEDLINE: 16007558]

\section{Sutton 2007 \{published data only\}}

* Sutton D, Higgins B, Stevens JM. Continuous ambulatory peritoneal dialysis patients are unable to increase dietary intake to recommended levels. Journal of Renal Nutrition 2007;17(5):329-35. [MEDLINE: 17720102]

Teng 2013 \{published data only\}

* Teng HL, Yen M, Fetzer S, Sung JM, Hung SY. Effects of targeted interventions on lifestyle modifications of chronic kidney disease patients: randomized controlled trial. Western Journal of Nursing Research 2013;35(9):1107-27. [MEDLINE: 23618821] 
Tzvetanov 2014 \{published data only\}

* Tzvetanov I, West-Thielke P, D'Amico G, Johnsen M, Ladik A, Hachaj $G$, et al. A novel and personalized rehabilitation program for obese kidney transplant recipients. Transplantation Proceedings 2014;46(10):3431-7. [MEDLINE: 25498067]

Whittier 1985 \{published data only\}

* Whittier FC, Evans DH, Dutton S, Ross G, Luger A, Nolph KD, et al. Nutrition in renal transplantation. American Journal of Kidney Diseases 1985;6(6):405-11. [MEDLINE: 3907334]

\section{Zhou 2011b \{published data only\}}

* Zhou XR, Yu K, Tang QQ. Effects of nutritional intervention and individualized nursing on nutritional risk, undernutrition, and quality of life in end-stage renal disease patients with peritoneal dialysis: a randomized controlled study. Chinese Journal of Clinical Nutrition 2011;19(4):222-6. [EMBASE: 362677283]

\section{References to studies excluded from this review}

\section{Parillo 1988 \{published data only\}}

* Parillo M, Riccardi G, Pacioni D, lovine C, Contaldo F, Isernia C, et al. Metabolic consequences of feeding a high-carbohydrate, high-fiber diet to diabetic patients with chronic kidney failure. American Journal of Clinical Nutrition 1988;48(2):255-9. [MEDLINE: 2841839]

\section{References to ongoing studies}

INTENT Study 2014 \{published data only\}

* Ryan KJ, Casas JM, Mash LE, McLellan SL, Lloyd LE, Stinear JW, et al. The effect of intensive nutrition interventions on weight gain after kidney transplantation: protocol of a randomised controlled trial. BMC Nephrology 2014;15:148. [MEDLINE: 25204676]

\section{Additional references}

\section{Abiemo 2012}

Abiemo EE, Alonso A, Nettleton JA, Steffen LM, Bertoni AG, Jain A, et al. Relationships of the Mediterranean dietary pattern with insulin resistance and diabetes incidence in the MultiEthnic Study of Atherosclerosis (MESA). British Journal of Nutrition 2013;109(8):1490-7. [MEDLINE: 22932232]

\section{Adler 2014}

Adler AJ, Taylor F, Martin N, Gottlieb S, Taylor RS, Ebrahim S. Reduced dietary salt for the prevention of cardiovascular disease. Cochrane Database of Systematic Reviews 2014, Issue 12. [DOI: 10.1002/14651858.CD009217.pub3]

\section{Anderson 2008}

Anderson R. New MRC guidance on evaluating complex interventions. BMJ 2008;337:a1937. [MEDLINE: 18945728]

\section{Chadban 2003}

Chadban SJ, Briganti EM, Kerr PG, Dunstan DW, Welborn TA, Zimmet PZ, et al. Prevalence of kidney damage in Australian adults: The AusDiab kidney study. Journal of the American
Society of Nephrology 2003;14(7 Suppl 2):S131-8. [MEDLINE: 12819318]

\section{Chen 2016}

Chen X, Wei G, Jalili T, Metos J, Giri A, Cho ME, et al. The associations of plant protein intake with all-cause mortality in CKD. American Journal of Kidney Diseases 2016;67(3):423-30. [MEDLINE: 26687923]

\section{Estruch 2013}

Estruch R, Ros E, Salas-Salvado J, Covas MI, Corella D, Aros F, et al. Primary prevention of cardiovascular disease with a Mediterranean diet. New England Journal of Medicine 2013;368(14):1279-90. [MEDLINE: 23432189]

\section{Fouque 2009}

Fouque D, Laville M. Low protein diets for chronic kidney disease in non diabetic adults. Cochrane Database of Systematic Reviews 2009, Issue 3. [DOI: 10.1002/14651858.CD001892.pub3]

\section{Go 2004}

Go AS, Chertow GM, Fan D, McCulloch CE, Hsu CY. Chronic kidney disease and the risks of death, cardiovascular events, and hospitalization. [Erratum appears in $\mathrm{N}$ Engl J Med. 2008;18(4):4]. New England Journal of Medicine 2004;351(13):1296-305. [MEDLINE: 15385656]

\section{GRADE 2008}

Guyatt GH, Oxman AD, Vist GE, Kunz R, Falck-Ytter Y, AlonsoCoello $P$, et al. GRADE: an emerging consensus on rating quality of evidence and strength of recommendations. BMJ 2008;336(7650):924-6. [MEDLINE: 18436948]

\section{Gutierrez 2014}

Gutierrez OM, Muntner P, Rizk DV, McClellan WM, Warnock DG, Newby PK, et al. Dietary patterns and risk of death and progression to ESRD in individuals with CKD: a cohort study. American Journal of Kidney Diseases 2014;64(2):204-13. [MEDLINE: 24679894]

\section{Hartley 2013}

Hartley L, Igbinedion E, Holmes J, Flowers N, Thorogood M, Clarke A, et al. Increased consumption of fruit and vegetables for the primary prevention of cardiovascular diseases. Cochrane Database of Systematic Reviews 2013, Issue 6. [DOI: 10.1002/14651858.CD009874.pub2]

\section{Hemmelgarn 2010}

Hemmelgarn BR, Manns BJ, Lloyd A, James MT, Klarenbach S, Quinn RR, et al. Relation between kidney function, proteinuria, and adverse outcomes. JAMA 2010;303(5):423-9. [MEDLINE: 20124537]

\section{Higgins 2003}

Higgins JP, Thompson SG, Deeks JJ, Altman DG. Measuring inconsistency in meta-analyses. BMJ 2003;327(7414):557-60. [MEDLINE: 12958120]

\section{Higgins 2011}

Higgins JP, Green S (editors). Cochrane Handbook for Systematic Reviews of Interventions Version 5.1.0 [updated 
March 2011]. The Cochrane Collaboration, 2011. Available from www.cochrane-handbook.org.

\section{Hoffmann 2014}

Hoffmann TC, Glasziou PP, Boutron I, Milne R, Perera R, Moher D, et al. Better reporting of interventions: template for intervention description and replication (TIDieR) checklist and guide. BMJ 2014;348:g1687. [MEDLINE: 24609605]

\section{Jha 2013}

Jha V, Garcia-Garcia G, Iseki K, Li Z, Naicker S, Plattner B, et al. Chronic kidney disease: global dimension and perspectives. [Erratum appears in Lancet. $2013 \mathrm{Jul}$ 20;382(9888):208]. Lancet 2013;382(9888):260-72. [MEDLINE: 23727169]

\section{Johnson 2011}

Johnson ES, Smith DH, Thorp ML, Yang X, Juhaeri J. Predicting the risk of end-stage renal disease in the population-based setting: a retrospective case-control study. BMC Nephrology 2011;12:17. [MEDLINE: 21545746]

\section{Jun 2012}

Jun M, Venkataraman V, Razavian M, Cooper B, Zoungas S, Ninomiya T, et al. Antioxidants for chronic kidney disease. Cochrane Database of Systematic Reviews 2012, Issue 10. [DOI: 10.1002/14651858.CD008176.pub2]

\section{KDIGO 2012}

Levin A, Stevens PE, Bilous RW, Coresh J, De Francisco AL, De Jong PE. Kidney Disease: Improving Global Outcomes (KDIGO) CKD Work Group. KDIGO 2012 clinical practice guideline for the evaluation and management of chronic kidney disease. Kidney International - Supplement 2013;3(1):1-150. [EMBASE: 369856107]

\section{Liu 2015}

Liu Z, Su G, Guo X, Wu Y, Liu X, Zou C, et al. Dietary interventions for mineral and bone disorder in people with chronic kidney disease. Cochrane Database of Systematic Reviews 2015, Issue 9. [DOI: 10.1002/14651858.CD010350.pub2]

\section{Manns 2014}

Manns B, Hemmelgarn B, Lillie E, Dip SC, Cyr A, Gladish M, et al. Setting research priorities for patients on or nearing dialysis. Clinical Journal of The American Society of Nephrology: CJASN 2014;9(10):1813-21. [MEDLINE: 24832095]

\section{McMahon 2015}

McMahon EJ, Campbell KL, Bauer JD, Mudge DW. Altered dietary salt intake for people with chronic kidney disease. Cochrane Database of Systematic Reviews 2015, Issue 2. [DOI: 10.1002/14651858.CD010070.pub2]

\section{Moore 2014}

Moore G, Audrey S, Barker M, Bond L, Bonell C, Cooper C, et al. Process evaluation in complex public health intervention studies: the need for guidance.[Erratum appears in J Epidemiol Community Health. 2014 Jun;68(6):585]. Journal of Epidemiology \& Community Health 2014;68(2):101-2. [MEDLINE: 24022816]

\section{Muntner 2013}

Muntner P, Judd SE, Gao L, Gutierrez OM, Rizk DV, McClellan W, et al. Cardiovascular risk factors in CKD associate with both ESRD and mortality. Journal of the American Society of Nephrology 2013;24(7):1159-65. [MEDLINE: 23704285]

\section{Nakayama 1996}

Nakayama M, Okuda S, Tamaki K, Fujishima M. Short- or long-term effects of a low-protein diet on fibronectin and transforming growth factor-beta synthesis in Adriamycininduced nephropathy. Journal of Laboratory \& Clinical Medicine 1996;127(1):29-39. [MEDLINE: 8592094]

\section{Nettleton 2008}

Nettleton JA, Steffen LM, Palmas W, Burke GL, Jacobs DR Jr. Associations between microalbuminuria and animal foods, plant foods, and dietary patterns in the Multiethnic Study of Atherosclerosis. American Journal of Clinical Nutrition 2008;87(6):1825-36. [MEDLINE: 18541574]

\section{Nield 2008}

Nield L, Summerbell CD, Hooper L, Whittaker V, Moore H. Dietary advice for the prevention of type 2 diabetes mellitus in adults. Cochrane Database of Systematic Reviews 2008, Issue 3. [DOI: 10.1002/14651858.CD005102.pub2]

\section{Orozco 2008}

Orozco LJ, Buchleitner AM, Gimenez-Perez G, Roque I Figuls M, Richter B, et al. Exercise or exercise and diet for preventing type 2 diabetes mellitus. Cochrane Database of Systematic Reviews 2008, Issue 3. [DOI: 10.1002/14651858.CD003054.pub3]

\section{Palmer 2015a}

Palmer SC, Hanson CS, Craig JC, Strippoli GF, Ruospo M, Campbell K, et al. Dietary and fluid restrictions in CKD: a thematic synthesis of patient views from qualitative studies. American Journal of Kidney Diseases 2015;65(4):559-73. [MEDLINE: 25453993]

\section{Peters 2000}

Peters H, Border WA, Noble NA. Angiotensin II blockade and low-protein diet produce additive therapeutic effects in experimental glomerulonephritis. Kidney International 2000;57(4):1493-501. [MEDLINE: 10760085]

\section{Rees 2013a}

Rees K, Dyakova M, Wilson N, Ward K, Thorogood M, Brunner E. Dietary advice for reducing cardiovascular risk. Cochrane Database of Systematic Reviews 2013, Issue 12. [DOI: 10.1002/14651858.CD002128.pub5]

\section{Rees 2013b}

Rees K, Hartley L, Flowers N, Clarke A, Hooper L, Thorogood M, et al. 'Mediterranean' dietary pattern for the primary prevention of cardiovascular disease. Cochrane Database of Systematic Reviews 2013, Issue 8. [DOI: 10.1002/14651858.CD009825.pub2]

\section{Robertson 2007}

Robertson LM, Waugh N, Robertson A. Protein restriction for diabetic renal disease. Cochrane Database of Systematic Reviews 2007, Issue 4. [DOI: 10.1002/14651858.CD002181.pub2] 


\section{Schunemann 2011a}

Schünemann HJ, Oxman AD, Higgins JP, Vist GE, Glasziou P, Guyatt GH. Chapter 11: Presenting results and 'Summary of findings' tables. In: Higgins JP, Green S (editors). Cochrane Handbook for Systematic Reviews of Interventions Version 5.1.0 [updated March 2011]. The Cochrane Collaboration, 2011. Available from www.cochrane-handbook.org.

\section{Schunemann 2011b}

Schünemann HJ, Oxman AD, Higgins JP, Deeks JJ, Glasziou P, Guyatt GH. Chapter 12: Interpreting results and drawing conclusions. In: Higgins JP, Green S (editors). Cochrane Handbook for Systematic Reviews of Interventions Version 5.1.0 [updated March 2011]. The Cochrane Collaboration, 2011. Available from www.cochrane-handbook.org.

\section{Singh 2009}

Singh NP, Ingle GK, Saini VK, Jami A, Beniwal P, Lal M, et al. Prevalence of low glomerular filtration rate, proteinuria and associated risk factors in North India using CockcroftGault and Modification of Diet in Renal Disease equation: an observational, cross-sectional study. BMC Nephrology 2009; Vol. 10:4. [MEDLINE: 19220921]

\section{Stamler 1996}

Stamler J, Caggiula A, Grandits G A, Kjelsberg M, Cutler JA. Relationship to blood pressure of combinations of dietary macronutrients. Findings of the Multiple Risk Factor Intervention Trial (MRFIT). Circulation 1996;94(10):2417-23. [MEDLINE: 8921782]

\section{Tong 2015}

Tong A, Crowe S, Chando S, Cass A, Chadban SJ, Chapman JR, et al. Research priorities in chronic kidney disease for Australia: report of a conference. American Journal of Kidney Diseases 2015;66(2):212-22. [DOI: 10.1053/j.ajkd.2015.02.341]

\section{Tong 2015a}

Tong A, Chando S, Crowe S, Manns B, Winkelmayer WC, Hemmelgarn $B$, et al. Research priority setting in kidney disease: a systematic review. American Journal of Kidney Diseases 2015;65(5):674-83. [MEDLINE: 25582284]

\section{Tong 2015b}

Tong A, Manns B, Hemmelgarn B, Wheeler DC, Tugwell P, Winkelmayer WC, et al. Standardised outcomes in nephrology - Haemodialysis (SONG-HD): study protocol for establishing a

\section{CHARACTERISTICS OF STUDIES}

Characteristics of included studies [ordered by study ID] core outcome set in haemodialysis. Trials [Electronic Resource] 2015;16:364. [PUBMED: 26285819]

\section{van Dijk 2012}

van Dijk SJ, Feskens EJ, Bos MB, de Groot LC, de Vries JH, Muller $\mathrm{M}$, et al. Consumption of a high monounsaturated fat diet reduces oxidative phosphorylation gene expression in peripheral blood mononuclear cells of abdominally overweight men and women. Journal of Nutrition 2012;142(7):1219-25. [MEDLINE: 22623392]

\section{Weiner 2006}

Weiner DE, Tabatabai S, Tighiouart H, Elsayed E, Bansal N, Griffith J, et al. Cardiovascular outcomes and all-cause mortality: exploring the interaction between CKD and cardiovascular disease. American Journal of Kidney Diseases 2006;48(3):392-401. [MEDLINE: 16931212]

\section{Wyld 2012}

Wyld M, Morton RL, Hayen A, Howard K, Webster AC. A systematic review and meta-analysis of utility-based quality of life in chronic kidney disease treatments. PLoS Medicine 2012;9(9):e1001307. [MEDLINE: 22984353]

\section{Zamora-Ros 2013}

Zamora-Ros R, Serafini M, Estruch R, Lamuela- Raventós RM, Martínez-González MA, Salas-Salvadó J, et al. Mediterranean diet and non enzymatic antioxidant capacity in the PREDIMED study: Evidence for a mechanism of antioxidant tuning. Nutrition, Metabolism \& Cardiovascular Diseases 2013;23(12):1167-74. [MEDLINE: 23484910]

\section{Zhang 2012}

Zhang L, Wang F, Wang L, Wang W, Liu B, Liu J, et al. Prevalence of chronic kidney disease in China: a cross-sectional survey. [Erratum appears in Lancet. 2012 Aug 18;380(9842):650]. Lancet 2012;379(9818):815-22. [MEDLINE: 22386035]

\section{References to other published versions of this review Palmer 2015b}

Palmer SC, Maggo JK, Campbell KL, Craig JC, Johnson DW, Sutanto B, et al. Dietary patterns for adults with chronic kidney disease. Cochrane Database of Systematic Reviews 2015, Issue 12. [DOI: 10.1002/14651858.CD011998]

* Indicates the major publication for the study

\section{Campbell 2008}

\begin{tabular}{ll}
\hline Methods & - Study design: parallel RCT \\
& - Recruitment: September 2004 to September 2005. \\
& - Duration: 12 weeks \\
\hline Participants & - Country: Australia
\end{tabular}


- Setting: single centre (predialysis clinic)

- Inclusion criteria: adults with CKD and GFR $<30 \mathrm{~mL} / \mathrm{min}$; absence of communication or intellectual impairment.

- Number: treatment group (31); control group (29)

- Mean age \pm SD (years): treatment group $(69.5 \pm 11.7)$; control group $(70.9 \pm 11.6)$

- Sex (M/F): treatment group (17/12); control group (17/10)

- Baseline characteristics

* Mean baseline BMI $\left(\mathrm{kg} / \mathrm{m}^{2}\right)$ : treatment group (26.8 \pm 4.7$)$; control group $(27.6 \pm 5.2)$

* Mean baseline $\mathrm{SCr}(\mathrm{mg} / \mathrm{dL})$ : treatment group (2.9 \pm 1.0$)$; control group $(3.0 \pm 0.9)$

* Mean baseline GFR (mL/min/1.73 $\left.\mathrm{m}^{2}\right)$ : treatment group (23.1 \pm 7.2$)$; control group (21.6 \pm 6.1$)$

* Mean baseline serum albumin $(\mathrm{g} / \mathrm{dL})$ : treatment group (3.9 \pm 0.5$)$; control group (3.9 \pm 0.4$)$

* Mean baseline calorie intake (kJ/kg): treatment group (101.8 \pm 23$)$; control group $(108.5 \pm 25.2)$

- Exclusion criteria: previously seen by dietitian for Stage IV CKD and malnutrition due to conditions other than CKD

- Single dietitian administered intervention over 12 weeks, intervention was based on nutrition therapy framework from the ADA. The intervention utilised self-management principles (goal setting, menu planning, label reading and identification of foods containing protein, sodium etc, depending on requirements) and was individualised to each participant (including energy 125 to $146 \mathrm{KJ} / \mathrm{kg} / \mathrm{d}$ and protein 0.75 to $1 \mathrm{~g} / \mathrm{kg} / \mathrm{d}$ ), incorporating KDOQI recommendations to provide intensive nutritional counselling with regular monitoring

- Initial individual consultation was provided by dietitian, and then patients were regularly monitored by telephone consultation, fortnightly for the first month, then monthly

- Duration: 12 weeks

Control group

- Participants received generic nutrition information (as provided in regular clinical practice) containing an overview of nutrition advice for CKD and co-morbidity management

- No individualised advice or monitoring was provided

- Duration: 12 weeks

Co-interventions

- Not reported

Outcomes

Dietary intake was assessed by using a 3-day food record. Participants were requested to estimate or measure all food and fluids consumed during those 3 days ( 2 weekdays and 1 weekend day). Food records were verified by the dietitian with visual food models and household measures to ensure accuracy.

- Body composition using total-body potassium counting (a measure of body cell mass)

- Kidney death

- Quality of life

- Change in energy intake

- Change in protein intake

- Change in body cell mass

- Weight

- eGFR

- Serum albumin

- CRP

Notes

- Funding source: Royal Brisbane and Women's Hospital Foundation Seeding grant, Queensland University of Technology Postgraduate Research Award (PhD scholarship), and an Institute of Health and Biomedical Innovation Research Scholarship 
Campbell 2008 (Continued)

- Additional data: none requested

\section{Risk of bias}

\begin{tabular}{|c|c|c|}
\hline Bias & Authors' judgement & Support for judgement \\
\hline $\begin{array}{l}\text { Random sequence genera- } \\
\text { tion (selection bias) }\end{array}$ & Low risk & Computer-generated number sequence \\
\hline $\begin{array}{l}\text { Allocation concealment } \\
\text { (selection bias) }\end{array}$ & Low risk & "Concealed to the recruiting officer". \\
\hline $\begin{array}{l}\text { Blinding of participants } \\
\text { and personnel (perfor- } \\
\text { mance bias) } \\
\text { All outcomes }\end{array}$ & High risk & $\begin{array}{l}\text { Masking of patients or study personnel not reported in the study report. Par- } \\
\text { ticipants were randomised to individualised nutritional counselling or written } \\
\text { education material. Therefore, the study was unlikely to be blinded }\end{array}$ \\
\hline $\begin{array}{l}\text { Blinding of outcome as- } \\
\text { sessment (detection bias) } \\
\text { Objective outcomes }\end{array}$ & Unclear risk & Insufficient information to permit judgement \\
\hline $\begin{array}{l}\text { Incomplete outcome data } \\
\text { (attrition bias) } \\
\text { All outcomes }\end{array}$ & Low risk & All patient outcome data reported \\
\hline $\begin{array}{l}\text { Selective reporting (re- } \\
\text { porting bias) }\end{array}$ & Low risk & All expected outcomes reported \\
\hline Other bias & Low risk & Study appears free of other biases \\
\hline
\end{tabular}

Chanwikrai 2012

\begin{tabular}{ll}
\hline Methods & Study design: parallel RCT \\
- & Time frame: not reported \\
\hline Participants & Duration: 12 weeks \\
- & Country: Thailand \\
- Setting: not reported \\
- Inclusion criteria: adult patients with stage 3 to 5 CKD \\
- Number: treatment group 1 (28); treatment group 2 (26); control group (27) \\
- Mean age \pm SD (years): not reported \\
- Sex (M/F): not reported \\
- Baseline characteristics \\
$*$ Mean body weight (kg): treatment groups (62.8); control group (56.0) \\
$*$ Mean SCr (units); not reported \\
$*$ Baseline GFR (units); not reported \\
$*$ Mean baseline serum albumin (g/dL): not reported \\
$*$ Mean baseline calorie intake (kcal): not reported \\
- Exclusion criteria: not reported \\
\hline
\end{tabular}

Control group
Interventions $\quad$ Details regarding standard care not reported. Non-supplement group
Treatment group 1


Chanwikrai 2012 (Continued)

- Diet managed
$*$ Advised to consume low protein ( 0.6 to $0.8 \mathrm{~g} / \mathrm{kg} / \mathrm{d})$ and low salt $(5 \mathrm{~g} / \mathrm{d})$ diet
* Participated in empowerment activities: details not provided

Treatment group 2

- Diet plus exercise managed

* Advised to consume low protein ( 0.6 to $0.8 \mathrm{~g} / \mathrm{kg} / \mathrm{d}$ ) and low salt (5 g/d) diet

* Advised to exercise

* Participated in empowerment activities: details not provided

Co-interventions

- None reported

\begin{tabular}{ll}
\hline Outcomes & - SCr \\
& - BUN \\
& - Serum albumin \\
& - Urine sodium \\
& - FBP and DBP \\
\hline Notes & - Additional data: none requested \\
& - Abstract-only publication \\
& Trial registration number not reported
\end{tabular}

\section{Risk of bias}

\begin{tabular}{|c|c|c|}
\hline Bias & Authors' judgement & Support for judgement \\
\hline $\begin{array}{l}\text { Random sequence genera- } \\
\text { tion (selection bias) }\end{array}$ & Unclear risk & Insufficient information to permit judgement \\
\hline $\begin{array}{l}\text { Allocation concealment } \\
\text { (selection bias) }\end{array}$ & Unclear risk & Insufficient information to permit judgement \\
\hline $\begin{array}{l}\text { Blinding of participants } \\
\text { and personnel (perfor- } \\
\text { mance bias) } \\
\text { All outcomes }\end{array}$ & High risk & $\begin{array}{l}\text { Masking of patients or study personnel not reported in the study report. Partic- } \\
\text { ipants were randomised to either control group, diet only or diet and exercise } \\
\text { group. Therefore, the study was unlikely to be blinded }\end{array}$ \\
\hline $\begin{array}{l}\text { Blinding of outcome as- } \\
\text { sessment (detection bias) } \\
\text { Objective outcomes }\end{array}$ & Unclear risk & Insufficient information to permit judgement \\
\hline $\begin{array}{l}\text { Incomplete outcome data } \\
\text { (attrition bias) } \\
\text { All outcomes }\end{array}$ & Low risk & $\begin{array}{l}96 \% \text { of the participants completed study and probably equal numbers in each } \\
\text { group completed study intervention }\end{array}$ \\
\hline $\begin{array}{l}\text { Selective reporting (re- } \\
\text { porting bias) }\end{array}$ & High risk & $\begin{array}{l}\text { No pre-published study protocol. Unclear whether treatment outcomes were } \\
\text { reported as planned. Clinical outcomes including mortality and ESKD not re- } \\
\text { ported }\end{array}$ \\
\hline Other bias & High risk & $\begin{array}{l}\text { Insufficient reporting information to fully adjudicate risk. Published only as } \\
\text { conference proceeding. Funding source(s) not provided. Trial registration not } \\
\text { provided }\end{array}$ \\
\hline
\end{tabular}


DIRECT Study 2013

\begin{tabular}{|c|c|}
\hline Methods & $\begin{array}{l}\text { - Study design: parallel RCT } \\
\text { - Time frame: July } 2005 \text { and June } 2007 \\
\text { - Duration: } 24 \text { months }\end{array}$ \\
\hline Participants & 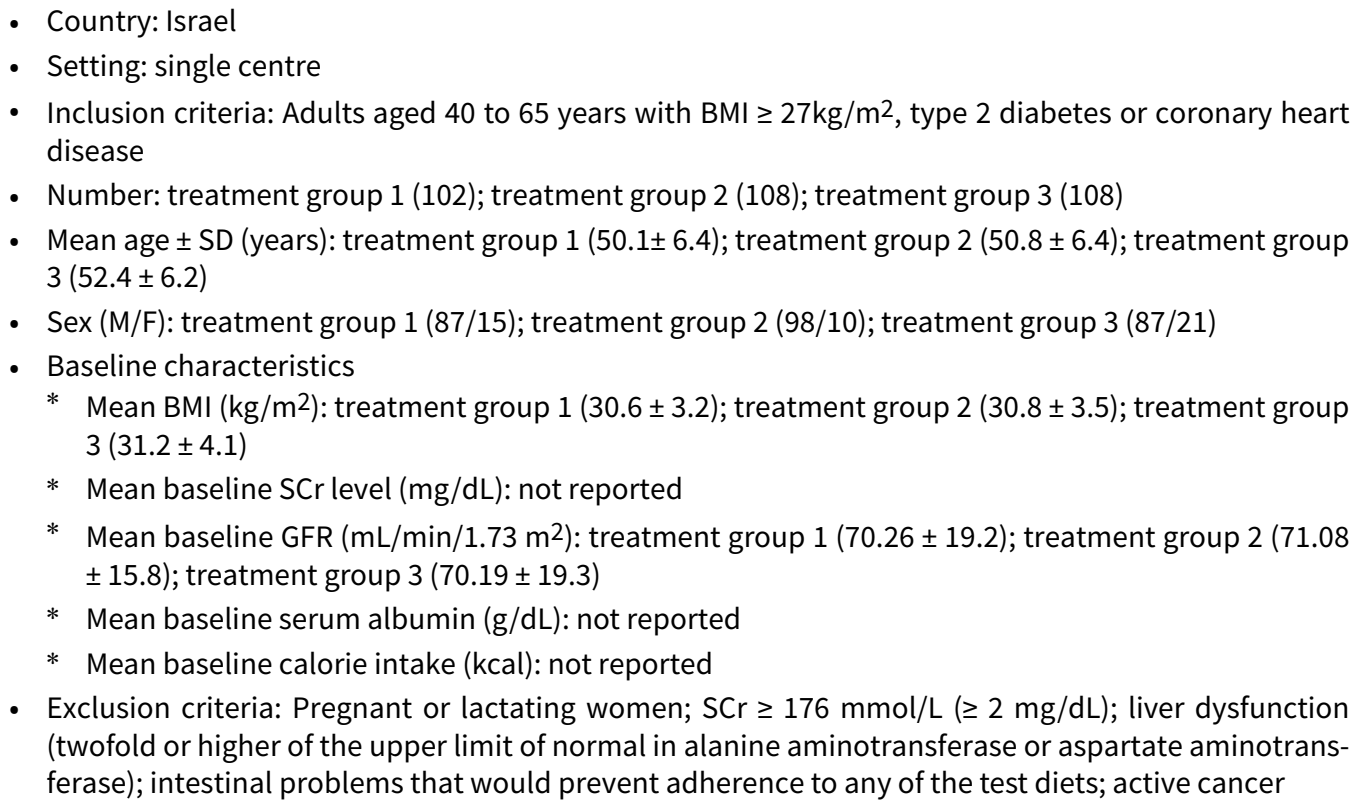 \\
\hline
\end{tabular}

\begin{tabular}{|c|c|}
\hline Interventions & $\begin{array}{l}\text { Treatment group } 1 \\
\text { - Low fat diet } \\
* \text { Participants in this group were advised to consume die low in fat with restricted calories } \\
\text { Treatment group } 2 \\
\text { - Low carbohydrate diet } \\
* \text { Participants in this group were advises to consume diet low in carbohydrates without calorie re- } \\
\quad \text { striction } \\
\text { Treatment group } 3 \\
\text { - Mediterranean diet } \\
\text { Participants in this group were advised to consume diet based on Mediterranean diet with calorie } \\
\text { Co-interventions } \\
\text { - None }\end{array}$ \\
\hline Outcomes & $\begin{array}{l}\text { - } \text { eGFR change } \\
\text { - Albumin to creatinine ratio } \\
\text { - Urine albumin } \\
\text { - Urine creatinine }\end{array}$ \\
\hline Notes & $\begin{array}{l}\text { - Funding source: The Israeli Ministry of Health, Chief Scientist Office (Project No. 300000-4850) and The } \\
\text { Dr. Robert C. and Veronica Atkins Research Foundation. } \\
\text { - Additional data: none requested } \\
\text { - ClinicalTrials.gov number, NCT00160108 }\end{array}$ \\
\hline
\end{tabular}


DIRECT Study 2013 (Continued)

Risk of bias

\begin{tabular}{|c|c|c|}
\hline Bias & Authors' judgement & Support for judgement \\
\hline $\begin{array}{l}\text { Random sequence genera- } \\
\text { tion (selection bias) }\end{array}$ & Unclear risk & Insufficient information to permit judgement \\
\hline $\begin{array}{l}\text { Allocation concealment } \\
\text { (selection bias) }\end{array}$ & Unclear risk & Insufficient information to permit judgement \\
\hline $\begin{array}{l}\text { Blinding of participants } \\
\text { and personnel (perfor- } \\
\text { mance bias) } \\
\text { All outcomes }\end{array}$ & High risk & $\begin{array}{l}\text { Masking of patients or study personnel not reported in the study report. Partic- } \\
\text { ipants were randomised to either low fat, low carbohydrate, or Mediterranean } \\
\text { diet. Therefore, participants and investigators (dietitians) were unlikely to be } \\
\text { masked to treatment allocation. }\end{array}$ \\
\hline $\begin{array}{l}\text { Blinding of outcome as- } \\
\text { sessment (detection bias) } \\
\text { Objective outcomes }\end{array}$ & Low risk & $\begin{array}{l}\text { The clinic and laboratory staff members were unaware of the treatment as- } \\
\text { signments, and the study coordinators were unaware of all outcome data until } \\
\text { the end of the intervention }\end{array}$ \\
\hline $\begin{array}{l}\text { Incomplete outcome data } \\
\text { (attrition bias) } \\
\text { All outcomes }\end{array}$ & Low risk & $\begin{array}{l}322 \text { participants were randomised, baseline data were available for } 318 \text { partic- } \\
\text { ipants. Data for all randomised participants were included in analyses in pri- } \\
\text { mary study report }\end{array}$ \\
\hline $\begin{array}{l}\text { Selective reporting (re- } \\
\text { porting bias) }\end{array}$ & High risk & $\begin{array}{l}\text { No pre-published study protocol. Unclear whether treatment outcomes are re- } \\
\text { ported as planned. Data for mortality and ESKD not reported }\end{array}$ \\
\hline Other bias & High risk & Post-hoc reporting of subgroups with CKD \\
\hline
\end{tabular}

\section{Facchini 2003}

\begin{tabular}{|c|c|}
\hline Methods & $\begin{array}{l}\text { - Study design: parallel RCT } \\
\text { - Time frame: not reported } \\
\text { - Duration: } 4 \text { years }\end{array}$ \\
\hline Participants & 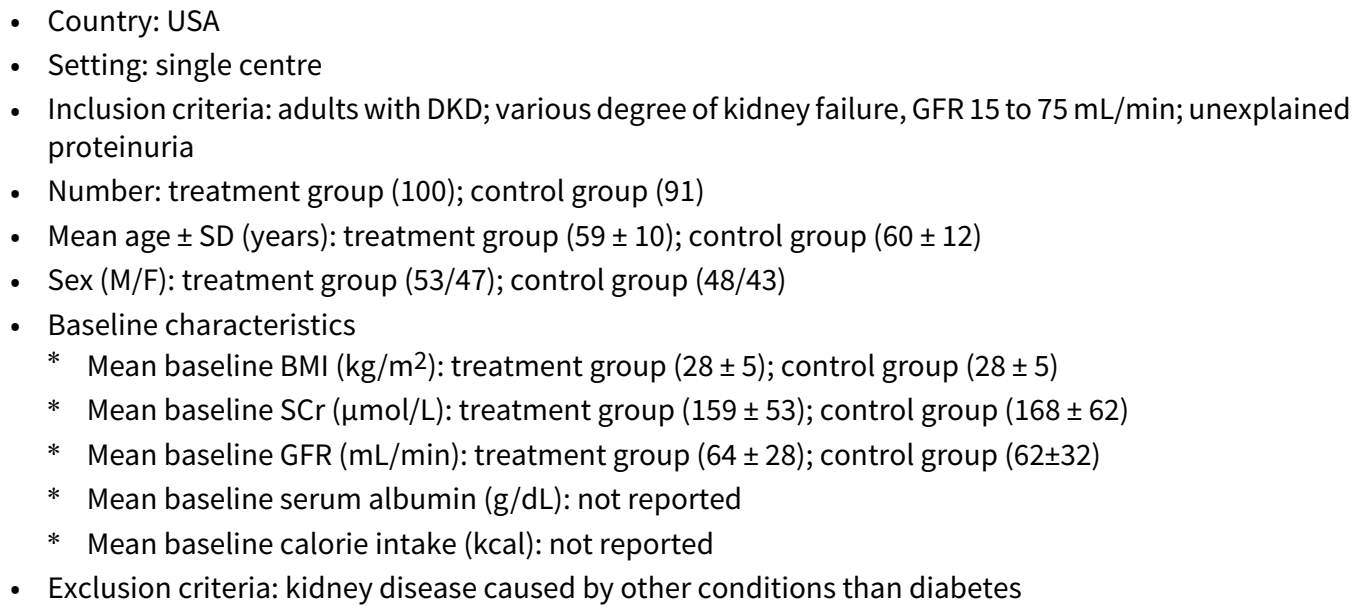 \\
\hline
\end{tabular}

Treatment group
\[ \begin{array}{ll}\text { Interventions } & \text { CR-LIPE diet } \\ * & 50 \% \text { reduction of previous carbohydrate consumption, substitution of iron-enriched red meats } \\ & \text { with iron poor white meats and with protein-enriched food items known to inhibit iron absorption }\end{array} \]


Facchini 2003 (Continued)

(diary, eggs and soy), elimination of all beverages other than tea, water and red wine (milk was recommended for breakfast, tea was highly recommended: red wine was not to exceed $150 \mathrm{~mL}$ with lunch and $150 \mathrm{~mL}$ with dinner; outside mealtimes, water was the only approved beverage), lastly exclusive use of polyphenol-enriched extra virgin olive oil for both dressing and frying was recommended. Except for carbohydrate restriction, there was no other restriction on protein and fat. Dietary adherence methods were not reported.

* Duration: mean follow-up $3.9+1.8$ years

Control group

- Participants in control group were recommended diet standard protein restricted diet $(0.8 \mathrm{~g} / \mathrm{kg} / \mathrm{d})$, isocaloric for ideal body weight maintenance, no specific recommendations were given regarding pattern of beverage use (except for avoiding sucrose-containing beverages). Dietary adherence methods were not reported.

- Duration: mean follow-up $3.9+1.8$ years.

Co-interventions

- Not reported

\begin{tabular}{ll}
\hline Outcomes & Doubling of SCr \\
& ESKD: a sustained elevation of $\mathrm{SCr}$ concentration to levels $>530 \mu \mathrm{mol} / \mathrm{L}(6.0 \mathrm{mg} \%))$, RRT, or transplan- \\
& tation \\
\hline & All-cause mortality \\
\hline Notes & Funding source: not reported \\
& - Additional data: none requested \\
& Trial registration: not applicable as published before 2006 \\
\hline
\end{tabular}

\section{Risk of bias}

\begin{tabular}{|c|c|c|}
\hline Bias & Authors' judgement & Support for judgement \\
\hline $\begin{array}{l}\text { Random sequence genera- } \\
\text { tion (selection bias) }\end{array}$ & Unclear risk & Insufficient information to permit judgement \\
\hline $\begin{array}{l}\text { Allocation concealment } \\
\text { (selection bias) }\end{array}$ & Unclear risk & Insufficient information to permit judgement \\
\hline $\begin{array}{l}\text { Blinding of participants } \\
\text { and personnel (perfor- } \\
\text { mance bias) } \\
\text { All outcomes }\end{array}$ & High risk & $\begin{array}{l}\text { Masking of patients or study personnel not reported in the study report. Par- } \\
\text { ticipants were randomised to either specific dietary recommendation group } \\
\text { or control group. Therefore, participants and investigators were unlikely to be } \\
\text { masked to treatment allocation }\end{array}$ \\
\hline $\begin{array}{l}\text { Blinding of outcome as- } \\
\text { sessment (detection bias) } \\
\text { Objective outcomes }\end{array}$ & Unclear risk & $\begin{array}{l}\text { Masking of outcome assessment not reported in the study report. Biochemi- } \\
\text { cal parameters are unlikely to be influenced by knowledge of treatment group, } \\
\text { however, clinical outcomes such as mortality and quality of life could have } \\
\text { been affected by knowledge of treatment allocation }\end{array}$ \\
\hline $\begin{array}{l}\text { Incomplete outcome data } \\
\text { (attrition bias) } \\
\text { All outcomes }\end{array}$ & Low risk & $\begin{array}{l}9 \text { participants in CR-LIPE group and } 12 \text { in control group loss to follow-up; with- } \\
\text { drawal reasons included loss of insurance or moving out of town. Data avail- } \\
\text { able for } 90 \% \text { of population. No imbalance between treatment groups }\end{array}$ \\
\hline $\begin{array}{l}\text { Selective reporting (re- } \\
\text { porting bias) }\end{array}$ & Low risk & $\begin{array}{l}\text { No pre-published study protocol. Unclear whether treatment outcomes are re- } \\
\text { ported as planned. Outcomes of mortality and ESKD provided }\end{array}$ \\
\hline Other bias & Unclear risk & Funding source not reported \\
\hline
\end{tabular}


Flesher 2011

\begin{tabular}{|c|c|}
\hline Methods & $\begin{array}{l}\text { - Study design: parallel RCT } \\
\text { - Time frame: not reported } \\
\text { - Duration: } 12 \text { months }\end{array}$ \\
\hline Participants & 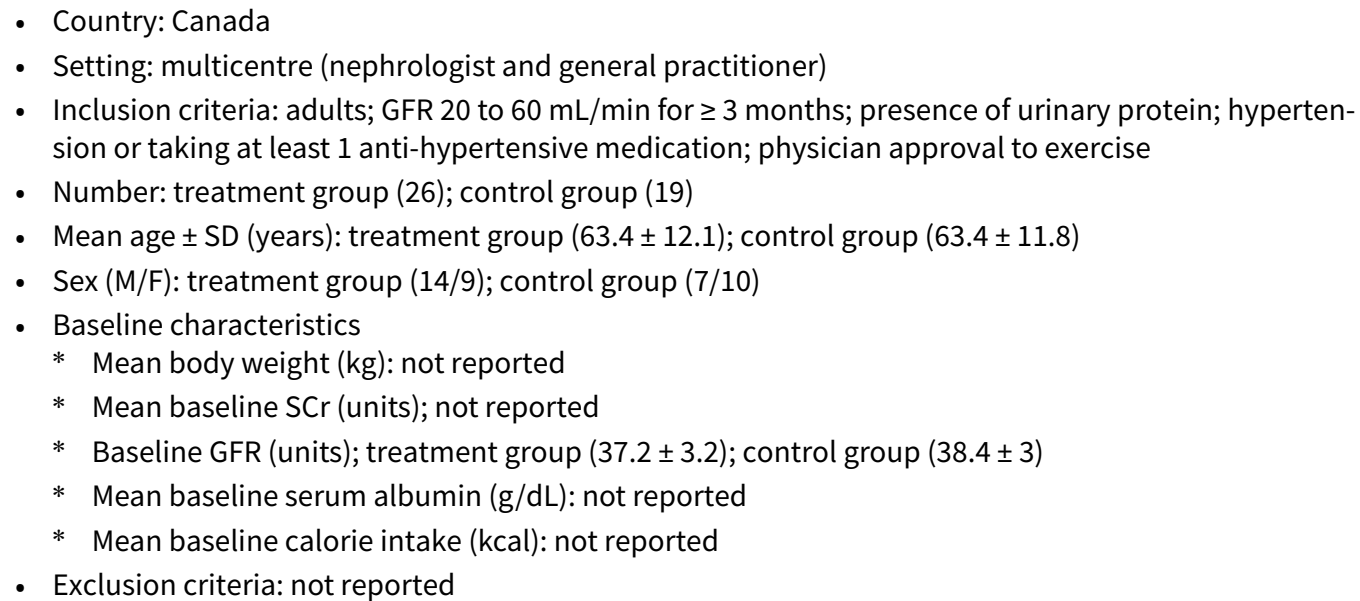 \\
\hline
\end{tabular}

Interventions

Treatment group

- Standard nutritional counselling plus a group CKD nutrition class, CKD cooking classes with a dietitian and cook educator, CKD cookbook and 12 week exercise programme led by a certified exercise physiologist and nurse

* The classes were offered in English, Cantonese, and Mandarin to accommodate the main languages spoken in the Richmond area. The cooking classes were offered over 4 weeks for 2 hours a session, and an additional week included a shopping tour led by a dietitian. Each cooking class focused on a different topic (self-management, sodium, protein, potassium, phosphate, label reading/eating out), with education provided by a dietitian and a cook educator leading participants in preparing and tasting recipes from the provided CKD cookbook. The 12-week exercise class was offered in the fully equipped gym consisted of 31 -hour sessions per week with aerobic, strength training, and flexibility components. Patients recorded their BP, monitored their heart rates with a heartrate monitor, and recorded both in an exercise log.

Control group

- Standard nutritional care including dietary counselling on moderate protein and low sodium, with individualised modification of potassium and/or phosphate. Patients did not complete food records, dietary history was discussed in detail at the individual appointment. Intervention group

Co-interventions

- Not reported

\begin{tabular}{ll}
\hline Outcomes & eGFR reduction \\
& - Total cholesterol reduction \\
& - Urinary sodium reduction \\
- & BP reduction \\
\hline Notes & - Funding source: Vancouver Coastal Health Professional Research Award 2008 \\
& - Trial registration number: not reported
\end{tabular}


Flesher 2011 (Continued)

Risk of bias

\begin{tabular}{|c|c|c|}
\hline Bias & Authors' judgement & Support for judgement \\
\hline $\begin{array}{l}\text { Random sequence genera- } \\
\text { tion (selection bias) }\end{array}$ & Unclear risk & Insufficient information to permit judgement \\
\hline $\begin{array}{l}\text { Allocation concealment } \\
\text { (selection bias) }\end{array}$ & Unclear risk & Insufficient information to permit judgement \\
\hline $\begin{array}{l}\text { Blinding of participants } \\
\text { and personnel (perfor- } \\
\text { mance bias) } \\
\text { All outcomes }\end{array}$ & High risk & $\begin{array}{l}\text { Masking of patients or study personnel not reported in the study report. Par- } \\
\text { ticipants were randomised to standard nutritional care or standard nutritional } \\
\text { care plus group nutrition class, cooking class and exercise training. Therefore, } \\
\text { the study was unlikely to be blinded }\end{array}$ \\
\hline $\begin{array}{l}\text { Blinding of outcome as- } \\
\text { sessment (detection bias) } \\
\text { Objective outcomes }\end{array}$ & Unclear risk & $\begin{array}{l}\text { Masking of outcome assessment not reported in the study report. Biochemi- } \\
\text { cal parameters are unlikely to be influenced by knowledge of treatment group, } \\
\text { however, clinical outcome like improvement in BP can be affected by knowl- } \\
\text { edge of treatment group }\end{array}$ \\
\hline $\begin{array}{l}\text { Incomplete outcome data } \\
\text { (attrition bias) } \\
\text { All outcomes }\end{array}$ & Low risk & $\begin{array}{l}3 / 26 \text { participants in intervention group did not complete study ( } 1 \text { patient died } \\
\text { in this group of unrelated health issues); } 2 / 19 \text { participants in control group did } \\
\text { not complete study. No imbalance between groups }\end{array}$ \\
\hline $\begin{array}{l}\text { Selective reporting (re- } \\
\text { porting bias) }\end{array}$ & Low risk & $\begin{array}{l}\text { No pre-published study protocol. Unclear whether treatment outcomes were } \\
\text { reported as planned. All-cause mortality data were provided }\end{array}$ \\
\hline Other bias & Low risk & Study appears free of other biases \\
\hline
\end{tabular}

Goraya 2013

$\begin{array}{ll}\text { Methods } & \text { - Study design: parallel RCT } \\ & \text { - Time frame: not reported } \\ & \text { - Duration: } 12 \text { months }\end{array}$

Participants

- Country: USA

- Setting: single centre

- Inclusion criteria: adults; GFR of 15 to $29 \mathrm{~mL} / \mathrm{min} / 1.73 \mathrm{~m}^{2}$; plasma $\mathrm{TCO}_{2}<22 \mathrm{mM}$; no diabetes or cardiovascular disease; 2 or more primary care physician visits in the preceding year

- Number: treatment group 1 (36); treatment group 2 (37)

- Mean age \pm SD (years): treatment group 1 (53.9 \pm 6.9$)$; treatment group $2(54.2 \pm 5.3)$

- Sex (M/F):treatment group 1 (20/16); treatment group $2(18 / 17)$

- Baseline characteristics

* Mean body weight $(\mathrm{kg})$ : treatment group 1 (82.7 \pm 6.1$)$; treatment group 2 (84.3 \pm 5.4$)$

* Mean baseline $\mathrm{SCr}(\mathrm{mg} / \mathrm{dL})$; treatment group 1 ( $3.9 \pm 0.9)$; treatment group $2(3.9 \pm 0.3)$

* Mean baseline GFR (units); not reported

* Mean baseline serum albumin (g/dL): not reported

* Mean baseline calorie intake (kcal): not reported

- Exclusion criteria: patients with primary kidney disease or findings consistent with $>3 \mathrm{RBC} / \mathrm{HPF}$ or urine cellular casts; history of diabetes or fasting blood glucose level > $110 \mathrm{mg} / \mathrm{dL}$; current pregnancy; history of malignancies; chronic infections; clinical evidence of cardiovascular disease; peripheral oedema or diagnosis associated with oedema, such as heart or liver failure or nephrotic syndrome; plasma potassium level $>4.6 \mathrm{mEq} / \mathrm{L}$; taking or inability to stop taking drugs that limit $\mathrm{K}^{+}$excretion 
Goraya 2013 (Continued)

Interventions
Treatment group 1

Fruit and vegetable group

- Advised to consume fruit and vegetables. The patients in the fruits and vegetables group received fruits and vegetables free of charge, prescribed by a dietitian and distributed from the food bank in amounts to reduce potential renal acid load by half, as done previously. Individuals were not given specific dietary instructions, and they integrated the prescribed fruits and vegetables into their diets as they wished.

Treatment group 2

Sodium bicarbonate group

- Participants in this group were advised to take $\mathrm{NaHCO}_{3}$ tablets and no added fruits and vegetables

All study individuals kept 3-day diaries before and after the intervention from which potential renal acid load, a measure of dietary acid intake, was calculated using a published equation

Co-interventions

- Not reported

\section{Risk of bias}

\begin{tabular}{|c|c|c|}
\hline Bias & Authors' judgement & Support for judgement \\
\hline $\begin{array}{l}\text { Random sequence genera- } \\
\text { tion (selection bias) }\end{array}$ & Unclear risk & Insufficient information to permit judgement \\
\hline $\begin{array}{l}\text { Allocation concealment } \\
\text { (selection bias) }\end{array}$ & Unclear risk & Insufficient information to permit judgement \\
\hline $\begin{array}{l}\text { Blinding of participants } \\
\text { and personnel (perfor- } \\
\text { mance bias) } \\
\text { All outcomes }\end{array}$ & High risk & $\begin{array}{l}\text { Masking of patients or study personnel not reported in the study report. Partic- } \\
\text { ipants were randomised to either sodium bicarbonate tablet or fruit and veg- } \\
\text { etables group. Therefore, the study was unlikely to be blinded. }\end{array}$ \\
\hline $\begin{array}{l}\text { Blinding of outcome as- } \\
\text { sessment (detection bias) }\end{array}$ & Unclear risk & $\begin{array}{l}\text { Masking of outcome assessment not reported in the study report. Biochemical } \\
\text { parameters are unlikely to be influenced by knowledge of treatment group. }\end{array}$ \\
\hline
\end{tabular}


Goraya 2013 (Continued)

Objective outcomes

\begin{tabular}{lll}
$\begin{array}{l}\text { Incomplete outcome data } \\
\text { (attrition bias) } \\
\text { All outcomes }\end{array}$ & Unclear risk & $\begin{array}{l}\text { Number of participants randomised was provided, however, number of partic- } \\
\text { ipants completing study and those analysed not provided. }\end{array}$ \\
\hline $\begin{array}{l}\text { Selective reporting (re- } \\
\text { porting bias) }\end{array}$ & High risk & $\begin{array}{l}\text { No pre-published study protocol. Unclear whether treatment outcomes are re- } \\
\text { ported as planned. No key clinical outcomes (mortality or ESKD) provided. }\end{array}$ \\
\hline Other bias & Low risk & Study appears free of other biases
\end{tabular}

\section{Goraya 2014}

\begin{tabular}{|c|c|}
\hline Methods & $\begin{array}{l}\text { - Study design: parallel RCT } \\
\text { - Time frame: not reported } \\
\text { - Duration: } 36 \text { months }\end{array}$ \\
\hline Participants & 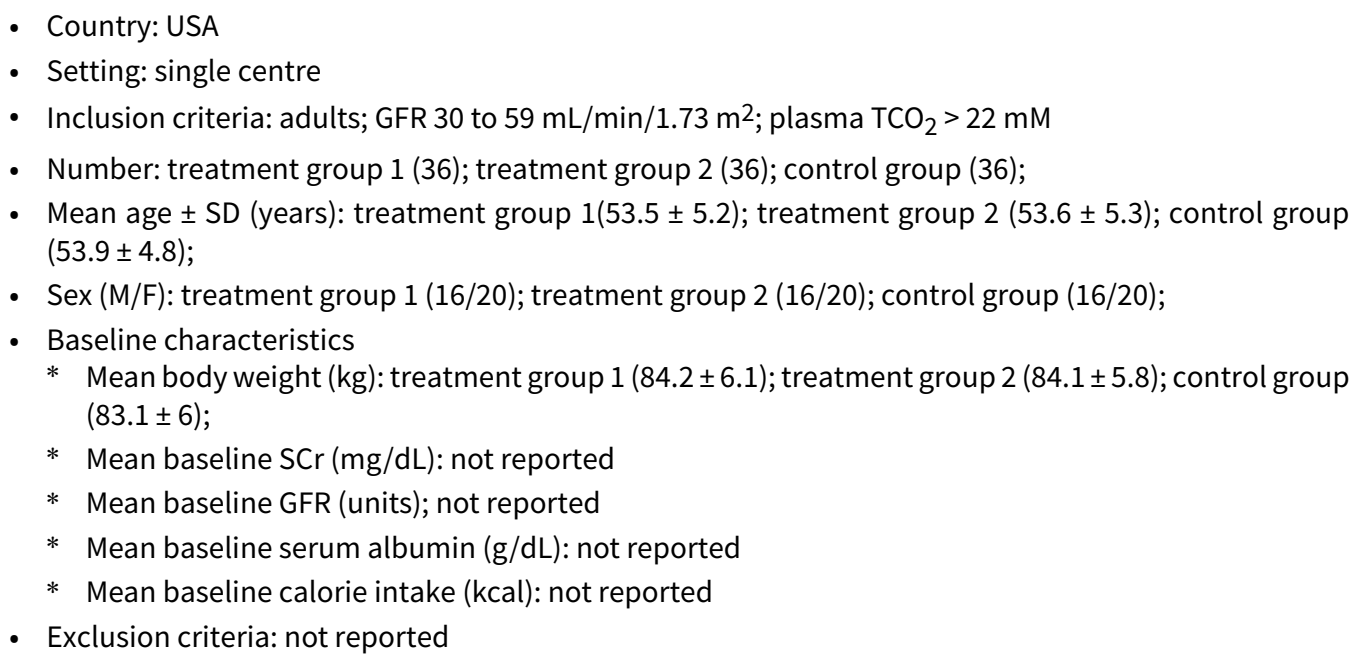 \\
\hline
\end{tabular}

\begin{tabular}{ll}
\hline Treatment group 1 \\
- Fruit and vegetable group \\
$*$ Advised to consume fruit and vegetables \\
Treatment group 2 \\
- Sodium bicarbonate group \\
$*$ Advised to take NaHCO ${ }_{3}$ tablets and no added fruits and vegetables \\
Control group \\
- Usual care \\
$*$ Continued their usual treatment. \\
Co-interventions \\
- Not reported \\
\hline - Weight \\
- BP \\
\hline Outcomes
\end{tabular}


Goraya 2014 (Continued)

- Plasma sodium

- 8 h urine $\mathrm{Na}^{+}$excretion

- Plasma $\mathrm{TCO}_{2}$

- Venous pH

- GFR

$\begin{array}{ll}\text { Notes } & \text { Funding source: The Larry and Jane Woirhaye Memorial Endowment in Renal Research the Texas Tech } \\ \text { University Health Sciences Centre, by the Statistics Department of Scott and White Healthcare, and } \\ \text { by the Academic Operations Division } \\ \text { - Additional data: none requested } \\ \text { - Trial registration number not provided }\end{array}$

\section{Risk of bias}

\begin{tabular}{|c|c|c|}
\hline Bias & Authors' judgement & Support for judgement \\
\hline $\begin{array}{l}\text { Random sequence genera- } \\
\text { tion (selection bias) }\end{array}$ & Unclear risk & Insufficient information to permit judgement \\
\hline $\begin{array}{l}\text { Allocation concealment } \\
\text { (selection bias) }\end{array}$ & Unclear risk & Insufficient information to permit judgement \\
\hline $\begin{array}{l}\text { Blinding of participants } \\
\text { and personnel (perfor- } \\
\text { mance bias) } \\
\text { All outcomes }\end{array}$ & High risk & $\begin{array}{l}\text { Masking of patients or study personnel not reported in the study report. Partic- } \\
\text { ipants were randomised to either sodium bicarbonate tablet or fruit and veg- } \\
\text { etables or usual care group. Therefore, the study was unlikely to be blinded }\end{array}$ \\
\hline $\begin{array}{l}\text { Blinding of outcome as- } \\
\text { sessment (detection bias) } \\
\text { Objective outcomes }\end{array}$ & Unclear risk & $\begin{array}{l}\text { Masking of outcome assessment not reported in the study report. Biochemical } \\
\text { parameters are unlikely to be influenced by knowledge of treatment group }\end{array}$ \\
\hline $\begin{array}{l}\text { Incomplete outcome data } \\
\text { (attrition bias) } \\
\text { All outcomes }\end{array}$ & Unclear risk & $\begin{array}{l}\text { Number of participants randomised is provided, however, number of partici- } \\
\text { pants completing study and those analysed not provided }\end{array}$ \\
\hline $\begin{array}{l}\text { Selective reporting (re- } \\
\text { porting bias) }\end{array}$ & High risk & $\begin{array}{l}\text { No pre-published study protocol. Unclear whether treatment outcomes are re- } \\
\text { ported as planned. No key clinical outcomes (mortality or ESKD) provided }\end{array}$ \\
\hline Other bias & Low risk & Study appears free of other biases \\
\hline
\end{tabular}

Leon 2006

$\begin{array}{ll}\text { Methods } & \text { Study design: cluster RCT } \\ \text { - Time frame: February } 2002 \text { to September } 2003 \\ \text { - }\end{array}$


Leon 2006 (Continued)

- Baseline characteristics

* Mean body weight (kg): treatment group (81.3); control group (78.0)

* Mean BMI (kg/m²): treatment group (29.0); control group (27.9)

* Mean baseline $\mathrm{SCr}(\mathrm{mg} / \mathrm{dL})$ : not reported

* Mean baseline GFR (units); not reported

* Mean baseline serum albumin (g/dL): treatment group (3.4); control group (3.4)

* Mean time on dialysis (years): treatment group (2.8); control group (3.1)

* Mean baseline energy intake (Kcal/d/kg): treatment group (0.83); control group (0.8)

- Exclusion criteria: people who did not speak English; mental impairment; unique nutritional issues (i.e., nursing home residents; people with cirrhosis; acquired immunodeficiency syndrome; active malignancy; terminal illness; tube feeding; and total parenteral nutrition).

Interventions

Treatment group

- Study coordinators educated people in this group about the meaning and importance of good nutritional status. They then provided feedback and recommendations. The information was provided during a dialysis treatment and was tailored to the specific barriers present. Study coordinators also communicated information about barriers to facility dietitians and modified recommendations. Participants received education about high protein foods using interactive activities, self-teaching activities and handouts. Study coordinators recommended increasing specific foods for which patients had preserved appetite and provided limited amounts of supplements such as nutrition drinks and cookies. Study coordinators in collaboration with facility dietitians and social workers explored the possibility of obtaining help from family, friends, and social support agencies. Participants were recommended to add a protein-containing beverage to diet. In addition, the following were addressed: dialysis dose, depression, difficulty chewing, difficulty swallowing, gastrointestinal symptoms, and acidosis

Control group

- Usual care from nephrologists, dietitians, and social workers. Study coordinators met monthly and administered questionnaires related to dietary intake, nutritional barriers, and quality of life

Co-interventions

- Not reported

\begin{tabular}{ll}
\hline Outcomes & Change in serum albumin level \\
- Weight \\
- Dietary intake \\
- Subjective global assessment \\
- Overcoming nutritional barriers \\
- Quality of life \\
\hline - Funding source: grants DK51472 and GCRC M01 RR00080 from the National Institutes of Health; \\
- Leonard C Rosenberg Renal Research Foundation \\
- Trial registration number not provided
\end{tabular}

\section{Risk of bias}

\begin{tabular}{lll}
\hline Bias & Authors' judgement & Support for judgement \\
\hline $\begin{array}{l}\text { Random sequence genera- } \\
\text { tion (selection bias) }\end{array}$ & Low risk & Computer-generated sequence \\
\hline $\begin{array}{l}\text { Allocation concealment } \\
\text { (selection bias) }\end{array}$ & Unclear risk & Insufficient information to permit judgement \\
\hline
\end{tabular}


Leon 2006 (Continued)

$\begin{array}{ll}\begin{array}{l}\text { Blinding of participants } \\ \text { and personnel (perfor- }\end{array} & \text { High risk } \\ \text { Insufficient information to permit judgement; unlikely to be adequately } \\ \text { masked due to nature of intervention }\end{array}$
masked due to nature of intervention mance bias)

All outcomes

$\begin{array}{lll}\text { Blinding of outcome as- } & \text { Unclear risk }\end{array}$ Insufficient information to permit judgement

Objective outcomes

Incomplete outcome data High risk (attrition bias)

All outcomes

\begin{tabular}{lll}
\hline $\begin{array}{l}\text { Selective reporting (re- } \\
\text { porting bias) }\end{array}$ & High risk & $\begin{array}{l}\text { No pre-published study protocol. Unclear whether treatment outcomes are re- } \\
\text { ported as planned. No key clinical outcomes (mortality or ESKD) provided }\end{array}$ \\
\hline Other bias & High risk & Did not account for effect of clustering in statistical analysis \\
\hline
\end{tabular}

17/103 people in intervention group and 11/105 people in control group not included in analyses.

Mekki 2010

\begin{tabular}{ll}
\hline Methods & Study design: parallel RCT \\
& - Time frame: January to April 2008 \\
& - Duration: 3 months
\end{tabular}

Participants

- Country: Algeria

- Setting: single centre

- Inclusion criteria: adults; moderate non dialysed CKD; GFR 60 to $89 \mathrm{~mL} / \mathrm{min}$; dyslipidaemia (triglycerides $>1.7 \mathrm{mmol} / \mathrm{L}$ and/or total cholesterol $>5 \mathrm{mmol} / \mathrm{L})$

- Number: treatment group (20); control group (20)

- Mean age \pm SD (years): treatment group (59 \pm 12$)$; control group $(60 \pm 10)$

- Sex (M/F): treatment group (10/10); control group (10/10)

- Baseline characteristics

* Mean body weight $(\mathrm{kg})$ : treatment group (73 \pm 11$)$; control group (76 \pm 14$)$

* Mean baseline SCr $(\mu \mathrm{mol} / \mathrm{mL})$ : treatment group $(151 \pm 57)$; control group $(189 \pm 70)$

* Mean baseline GFR (units): treatment group (70 \pm 10$)$; control group (75 \pm 15 )

* Mean baseline serum albumin $(\mathrm{g} / \mathrm{L})$ : treatment group ( $3.8 \pm 0.6)$; control group (3.2 \pm 0.5$)$

* Mean baseline calorie intake (kcal): not reported

- Exclusion criteria: DKD; thyroid disease; use of anti-inflammatory drugs, antioxidants or vitamins

Interventions

- All patients received nutritional advice based on the NKF K/DOQI (National Kidney Foundation-Kidney Disease Outcomes Quality Initiative) guidelines (energy intake of $0.12 \mathrm{MJ} / \mathrm{kg} \mathrm{BW/d}$, protein intake $0.75 \mathrm{~g} / \mathrm{kg}$ BW/d, lipid intake $35 \%$ and carbohydrates $55 \%$ of total energy intake)

- The food consumption survey used the method of "recall and record", repeated every 4 days. Patients were interviewed by trained interviewers using an adapted and structured questionnaire

Treatment group

- Dietary recommendations in this group were modified and adapted to a Mediterranean diet, with increased intake of MUFA, PUFA and fibres. Participants consumed olive oil and nuts for seasonings, whole grains (50 g of bread at each meal, $250 \mathrm{~g}$ of cereal or starch once a day), fruits (once a day), vegetables ( $200 \mathrm{~g}$ twice daily) and fish (twice a week). A list of foods rich in salt, potassium and phosphorus was provided. In addition, patients received advice about the cooking methods best suited for adherence to a Mediterranean diet

Control group 
Mekki 2010 (Continued)

- No modification to the NKF K/DOQI guidelines were made in this group

Co-interventions

- None specified

\begin{tabular}{ll}
\hline Outcomes & Food intake composition \\
- & Qualitative food intake \\
- SCr & GFR \\
- Serum urea \\
- Serum urate \\
- Serum iron \\
- Serum bilirubin \\
- Hb \\
- Serum albumin \\
- CRP \\
- Fibrinogen \\
- Serum cholesterol, HDL cholesterol, LDL cholesterol \\
- Triglycerides \\
\hline - Funding source: this work was supported by the National Agency of Health Research \\
- Additional data: none requested \\
- Trial registration number not provided
\end{tabular}

\section{Risk of bias}

\section{Bias}

Random sequence genera- Unclear risk tion (selection bias)

Allocation concealment
(selection bias)

\begin{tabular}{|c|c|c|}
\hline $\begin{array}{l}\text { Blinding of participants } \\
\text { and personnel (perfor- } \\
\text { mance bias) }\end{array}$ & High risk & $\begin{array}{l}\text { Masking of patients or study personnel not reported in the study report. Par- } \\
\text { ticipants were randomised to either modified diet Mediterranean diet group or } \\
\text { control group. Therefore, the study was unlikely to be blinded }\end{array}$ \\
\hline
\end{tabular}

\section{Authors' judgement Support for judgement}

Insufficient information to permit judgement

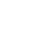

\section{Unclear risk}

Blinding of outcome as-
sessment (detection bias)

Objective outcomes

\begin{tabular}{lll}
\hline $\begin{array}{l}\text { Incomplete outcome data } \\
\text { (attrition bias) } \\
\text { All outcomes }\end{array}$ & Unclear risk & Only number of participants randomised provided \\
\hline $\begin{array}{l}\text { Selective reporting (re- } \\
\text { porting bias) }\end{array}$ & High risk & $\begin{array}{l}\text { No pre-published study protocol. Unclear whether treatment outcomes are re- } \\
\text { ported as planned. No key clinical outcomes (mortality or ESKD) provided. }\end{array}$ \\
\hline Other bias & Low risk & Study appears free of other biases \\
\hline
\end{tabular}


Orazio 2011

\begin{tabular}{|c|c|}
\hline Methods & $\begin{array}{l}\text { - Study design: parallel RCT } \\
\text { - Time frame: not reported } \\
\text { - Duration: } 24 \text { months }\end{array}$ \\
\hline Participants & 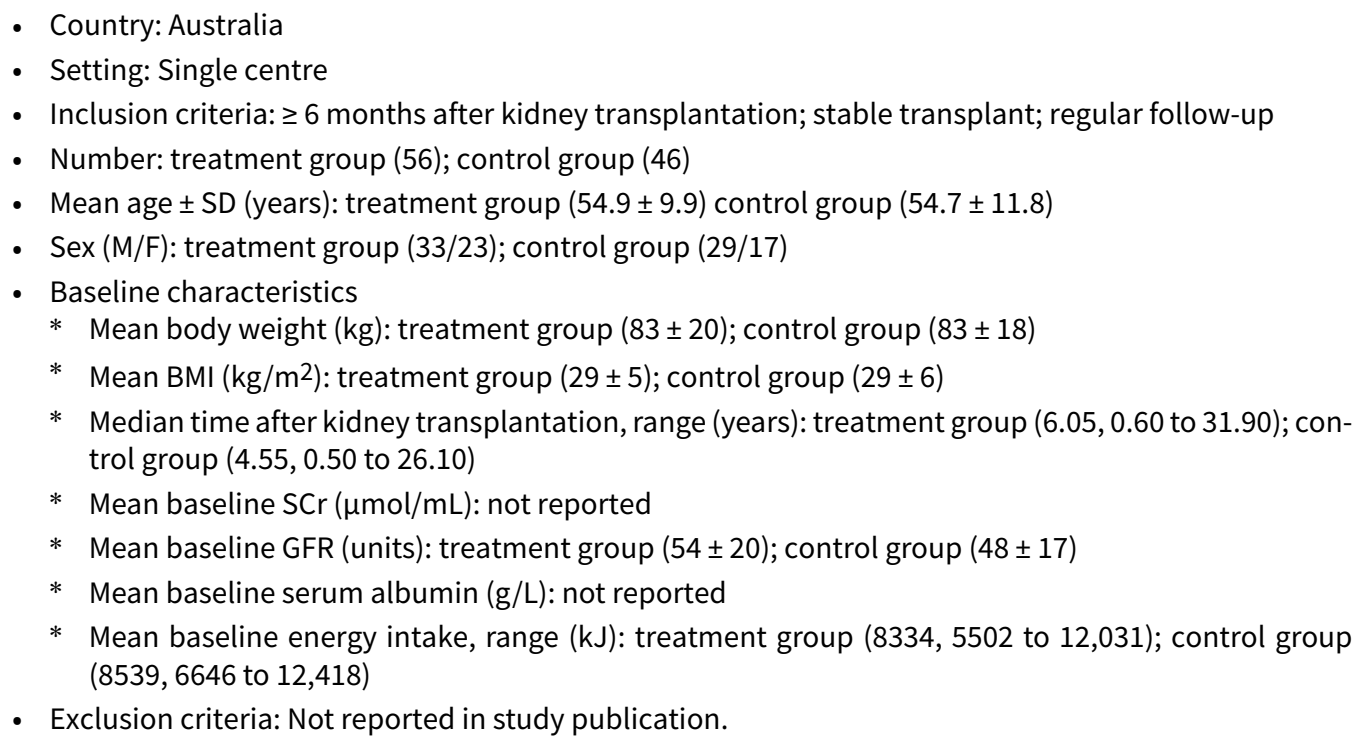 \\
\hline
\end{tabular}

- Individualised dietary advice including achievement and/or maintenance of a healthy weight (BMI 20 to $25 \mathrm{~kg} / \mathrm{m}^{2}$ ) using a Mediterranean style diet ( $<30 \%$ total energy from fat), low GI diet. A moderate energy deficit of $500 \mathrm{kcal} / \mathrm{d}(2000 \mathrm{~kJ} / \mathrm{d})$ was used to promote $0.5 \mathrm{~kg}$ weight loss/week. Study materials included a study manual with dietary and lifestyle information, food models and pictures. The longterm goal of physical activity advice was to achieve 150 minutes of accumulated physical activity per week. Goals were individualised according to mobility, fitness, personal preference, and self-efficacy for activities. Moderate physical activity such as walking was encouraged, both as a structured activity and activity of daily living. The Transtheoretical Model of Health Behaviour Change or Stage of Change Model underpinned the lifestyle intervention and was used to provide a framework for goal-setting in the study. The intervention was delivered by multidisciplinary team including dietitian, nephrologist, nurse and endocrinologist

Control

- Standard care

Co-interventions

- Not reported

\begin{tabular}{ll}
\hline - Autcomes & - HbAlc \\
- Total cholesterol, LDL cholesterol, HDL cholesterol, triglycerides \\
- Dietary intake: energy, protein, fat (total, poly, mono, saturated), carbohydrates, fibre \\
- Physical activity \\
- $\mathrm{VO}_{2}$ max \\
\hline - Funding source: Allied Health Research Scheme from Queensland Health; Allied Health Research \\
- Scholarship from the Princess Alexandra Hospital Foundation. \\
- Trial registration number not provided \\
\hline
\end{tabular}


Orazio 2011 (Continued)

Risk of bias

\begin{tabular}{|c|c|c|}
\hline Bias & Authors' judgement & Support for judgement \\
\hline $\begin{array}{l}\text { Random sequence genera- } \\
\text { tion (selection bias) }\end{array}$ & Unclear risk & Insufficient information to permit judgement \\
\hline $\begin{array}{l}\text { Allocation concealment } \\
\text { (selection bias) }\end{array}$ & Unclear risk & Insufficient information to permit judgement \\
\hline $\begin{array}{l}\text { Blinding of participants } \\
\text { and personnel (perfor- } \\
\text { mance bias) } \\
\text { All outcomes }\end{array}$ & High risk & $\begin{array}{l}\text { Insufficient information to permit judgement; unlikely due to the nature of the } \\
\text { interventions. }\end{array}$ \\
\hline $\begin{array}{l}\text { Blinding of outcome as- } \\
\text { sessment (detection bias) } \\
\text { Objective outcomes }\end{array}$ & Unclear risk & Insufficient information to permit judgement \\
\hline $\begin{array}{l}\text { Incomplete outcome data } \\
\text { (attrition bias) } \\
\text { All outcomes }\end{array}$ & Unclear risk & $\begin{array}{l}\text { Number of participants who were randomised and completed follow up not } \\
\text { reported. Unclear whether completeness of follow up similar for each treat- } \\
\text { ment group }\end{array}$ \\
\hline $\begin{array}{l}\text { Selective reporting (re- } \\
\text { porting bias) }\end{array}$ & High risk & $\begin{array}{l}\text { No pre-published study protocol. Unclear whether treatment outcomes are re- } \\
\text { ported as planned. No key clinical outcomes (mortality or ESKD) provided }\end{array}$ \\
\hline Other bias & Low risk & Study appears free of other biases \\
\hline
\end{tabular}

\section{Riccio 2014}

\begin{tabular}{|c|c|}
\hline Methods & $\begin{array}{l}\text { - Study design: parallel RCT } \\
\text { - Time frame: not reported } \\
\text { - Duration: } 6 \text { months }\end{array}$ \\
\hline Participants & $\begin{array}{l}\text { - Country: Italy } \\
\text { - Setting: not reported } \\
\text { - Inclusion criteria: adults with CKD stage 3B- } 5 \\
\text { - Number: Treatment group } 1 \text { (27); treatment group } 2 \text { (27) } \\
\text { - Mean age (years): treatment group } 1 \text { (66.6); treatment group } 2 \text { (61.5) } \\
\text { - Sex (M/F): not reported } \\
\text { - Baseline characteristics } \\
\text { * Mean body weight (kg): not reported } \\
\text { * Mean baseline SCr (units): not reported } \\
\text { * Baseline GFR (units): not reported } \\
\text { * Mean baseline serum albumin (g/dL): not reported } \\
\text { - Exclusion criteria: not reported. }\end{array}$ \\
\hline Interventions & $\begin{array}{l}\text { Treatment group } 1 \\
\text { - 6-point diet } \\
\text { * Advice on dietary modification, instructions were provided by a nephrologist. Instructions focused } \\
\text { on } 6 \text { points, including salt restriction, replacing food items, foods allowed and its quantity including } \\
\text { animal products and fruit and vegetable and combining different food items. Adherence to diet }\end{array}$ \\
\hline
\end{tabular}


Riccio 2014 (Continued)

was assessed at regular intervals (1, 3 and 6 months), method for assessing adherence was not reported.

- Duration: 6 months

Treatment group 2

- Low protein diet

* Instructed to consume diet containing 0.7 to $0.8 \mathrm{~g} / \mathrm{kg} / \mathrm{d}$ protein diet. Adherence to diet was assessed at regular intervals (1, 3 and 6 months), method for assessing adherence was not reported

- Duration: 6 months

Co-interventions

- Not reported

\begin{tabular}{ll}
\hline Outcomes & Protein intake \\
& - Phosphate intake \\
& - Weight loss \\
\hline Notes & - FrR (data not extractable) \\
& - Additional data: none requested \\
& - Abstract-only publication \\
\hline
\end{tabular}

\section{Risk of bias}

\begin{tabular}{|c|c|c|}
\hline Bias & Authors' judgement & Support for judgement \\
\hline $\begin{array}{l}\text { Random sequence genera- } \\
\text { tion (selection bias) }\end{array}$ & Unclear risk & Insufficient information to permit judgement \\
\hline $\begin{array}{l}\text { Allocation concealment } \\
\text { (selection bias) }\end{array}$ & Unclear risk & Insufficient information to permit judgement \\
\hline $\begin{array}{l}\text { Blinding of participants } \\
\text { and personnel (perfor- } \\
\text { mance bias) } \\
\text { All outcomes }\end{array}$ & High risk & $\begin{array}{l}\text { Masking of patients or study personnel not reported in the study report. Par- } \\
\text { ticipants were randomised to either } 6 \text { point dietary modification group of low } \\
\text { protein dietary modification group. Therefore, the study was unlikely to be } \\
\text { blinded. }\end{array}$ \\
\hline $\begin{array}{l}\text { Blinding of outcome as- } \\
\text { sessment (detection bias) } \\
\text { Objective outcomes }\end{array}$ & Unclear risk & Insufficient information to permit judgement \\
\hline $\begin{array}{l}\text { Incomplete outcome data } \\
\text { (attrition bias) } \\
\text { All outcomes }\end{array}$ & Unclear risk & $\begin{array}{l}\text { Number of participants randomised reported, number of participants who } \\
\text { completed or withdrew not provided. }\end{array}$ \\
\hline $\begin{array}{l}\text { Selective reporting (re- } \\
\text { porting bias) }\end{array}$ & High risk & $\begin{array}{l}\text { No pre-published study protocol. Unclear whether treatment outcomes are re- } \\
\text { ported as planned. Clinical outcomes (mortality, ESKD) not provided. }\end{array}$ \\
\hline Other bias & High risk & $\begin{array}{l}\text { Insufficient reporting information to adjudicate risk; published only as confer- } \\
\text { ence proceeding; funding source(s) not disclosed. }\end{array}$ \\
\hline
\end{tabular}


Stachowska 2005

\begin{tabular}{|c|c|}
\hline Methods & $\begin{array}{l}\text { - Study design: parallel RCT } \\
\text { - Time frame: not reported } \\
\text { - Duration: } 6 \text { months }\end{array}$ \\
\hline Participants & 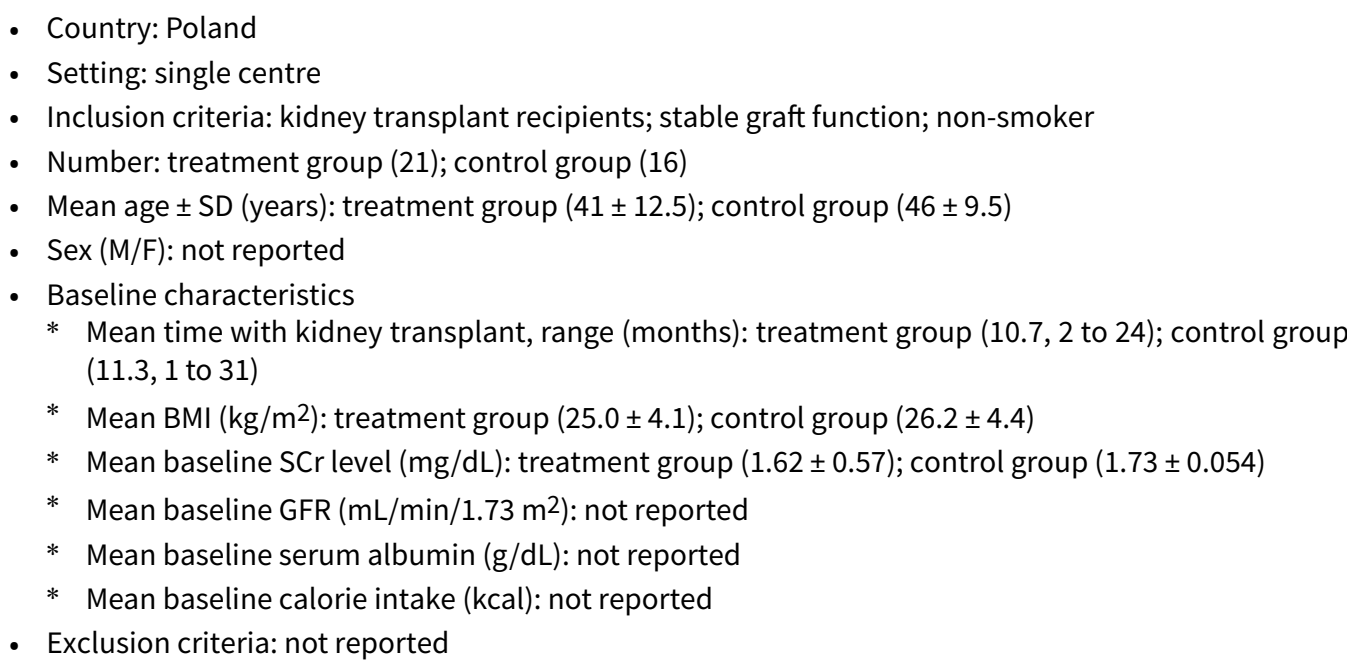 \\
\hline
\end{tabular}

Interventions

Treatment group

- Mediterranean diet in the form of 4-week all-day menus

* Daily energy intake was attributed as follows: $47 \%$ carbohydrates, $38 \%$ fatty acids (including $10 \%$ saturated, $22 \%$ monounsaturated and $6 \%$ polyunsaturated species) and $15 \%$ protein. Cholesterol and fibre supply was $165 \pm 17 \mathrm{mg} / \mathrm{d}$ and $47 \pm 9 \mathrm{~g} / \mathrm{d}$ respectively. The dominating fatty acid was oleic acid from olive oil and erucic acid-poor rapeseed oil. Patients consumed $30 \mathrm{~mL}$ cold-pressed olive oil per day (fresh salads) and prepared their cooked meals exclusively with rapeseed oil. Patients consumed approximately $30 \mathrm{~g}$ daily of products rich in a-tocopherol and a-linolenic acid C18:3n-3 (grains, flax-seed, nuts). The carbohydrate component contained less glucose (low glycaemic index). Allowable products included cereals, pulses, wholemeal bread, vegetables (fresh and cooked), oat flakes (cooked) and spaghetti. The patients were advised to consume fresh vegetables with every meal. The daily animal protein consumption was 25 to $50 \mathrm{~g}$ for men and 23 to 46 $\mathrm{g}$ for women, representing one-third of the total protein. No additional vitamin supplementation was offered.

Control group

- Standard care (low-fat diet isocaloric with the study diet)

* Patients were asked to take home and complete a $24 \mathrm{~h}$ diet diary. The diet diary booklet contained menus, pages to record foods, and photographs of food that depicted portion choices for a common food item. The dietician indicated that the patient should record the food brand and portion size. The amounts consumed were recorded in household units, by volume or by measuring with a ruler. Each person was interviewed about their dietary pattern in the previous month. Daily energy intake was attributed as follows: $57 \%$ carbohydrates, $26 \%$ fatty acids and $17 \%$ protein. Cholesterol and fibre supply was 257 (SD 15) $\mathrm{mg} / \mathrm{d}$ and 24 (SD 13) g/d respectively. The carbohydrate component was poor in cellulose and rich in starch (white bread, potatoes, rice). The fat content was lower than in the study group, with polyunsaturated (mainly C18:2n-6) fats dominating. Questionnaires revealed that butter and sunflower oil were the main source of fat in this group. Daily animal protein consumption was higher than in the study group (approximately $70 \mathrm{~g}$ for men and $50 \mathrm{~g}$ for women), whereas the consumption of fruit and fresh vegetables was lower. The diet was not supplemented with vitamins.

Co-interventions

- None 
Stachowska 2005 (Continued)

- Thiobarbituric acid-reactive substances in plasma and erythrocytes

- CRP

- Plasma a-tocopherol

- Superoxide dismutase

- Catalase

- Glutathione peroxidase

\begin{tabular}{ll}
\hline Notes & Funding source: Research grant No. 130-649 from the Pomeranian Medical University, Szczecin, \\
& Poland \\
- Additional data: none requested \\
- ClinicalTrials.gov number: not reported
\end{tabular}

\section{Risk of bias}

\begin{tabular}{lll}
\hline Bias & Authors' judgement & Support for judgement \\
\hline $\begin{array}{l}\text { Random sequence genera- } \\
\text { tion (selection bias) }\end{array}$ & Unclear risk & Insufficient information to permit judgement \\
\hline $\begin{array}{l}\text { Allocation concealment } \\
\text { (selection bias) }\end{array}$ & Unclear risk & Insufficient information to permit judgement \\
\hline
\end{tabular}

Blinding of participants High risk Masking of patients or study personnel not reported in the study report. Maskand personnel (perfor- $\quad$ ing was unlikely due to the nature of the interventions

mance bias)

All outcomes

Blinding of outcome as- Unclear risk Insufficient information to permit judgement

sessment (detection bias)

Objective outcomes

\begin{tabular}{lll}
\hline $\begin{array}{l}\text { Incomplete outcome data } \\
\text { (attrition bias) } \\
\text { All outcomes }\end{array}$ & Unclear risk & Insufficient information to permit judgement \\
\hline $\begin{array}{l}\text { Selective reporting (re- } \\
\text { porting bias) }\end{array}$ & High risk & $\begin{array}{l}\text { No pre-published study protocol. Unclear whether treatment outcomes are re- } \\
\text { ported as planned. Data for mortality and ESKD not reported }\end{array}$ \\
\hline Other bias & High risk & Typographical errors precluded assessment of baseline characteristics \\
\hline
\end{tabular}

\section{Sutton 2007}

$\begin{array}{ll}\text { Methods } & \text { Study design: parallel RCT } \\ \text { - Time frame: not reported } \\ \text { - Duration: } 4 \text { months }\end{array}$

\begin{tabular}{ll}
\hline Participants & Country: UK \\
- Setting: single centre \\
- Inclusion criteria: People treated with CAPD (without diabetes) for a minimum of 3 months \\
- Mean age \pm SD (years): treatment group $(60.7 \pm 15.5)$; control group $(58.5 \pm 15.4)$ \\
- Sex (M/F): treatment group $(15 / 11)$; control group $(12 / 11)$
\end{tabular}


Sutton 2007 (Continued)

- Baseline characteristics

* Mean body weight (kg): treatment group (72.8 \pm 12.9$)$; control group (72.0 \pm 12.1$)$

* Mean baseline BMI $\left(\mathrm{kg} / \mathrm{m}^{2}\right)$ : treatment group (25.4 \pm 3.8$)$; control group $(25.7 \pm 3.4)$

* Mean baseline $\mathrm{SCr}(\mu \mathrm{mol} / \mathrm{mL})$ : not reported

* Mean baseline GFR ( $\mathrm{mL} / \mathrm{min})$ : not reported

* Mean time on dialysis: not reported

* Mean baseline serum albumin $(\mathrm{g} / \mathrm{L})$ : treatment group (3.71 \pm 0.3$)$; control group $(3.72 \pm 0.32)$

* Mean baseline calorie intake (cal/kg): treatment group (23.4 \pm 6.1$)$; control group (25.7 \pm 5.9$)$

- Exclusion criteria: known malabsorption; celiac disease; malignancy; dementia; pregnancy; CKD; eating disorders

Treatment group
Interventions
Offered follow-up dietary advice that would encourage them to match energy intake with their esti-
mated energy expenditure allowing for dialysate calories and with a protein intake of not less than
0.8 to $1.0 \mathrm{~g} / \mathrm{kg} \mathrm{IBW}$. The allowance for dialysate calories was $5 \mathrm{cal} / \mathrm{kg}$ based on the median of results
of analysis of 24 -hour dialysate effluent. Suggestions of how to achieve a match were given as snack
ideas, alterations in food preparation, or modification of portion sizes, individualized in each case to
suit the preferences and eating patterns of the person participating. The reports were posted to the
participants to overcome variations in clinic attendance and accessibility to the renal unit on the basis
of geographic distance. Actual face-to-face contact with the research dietitian took place at baseline
and 4 months.

Control group

- Standard care

Co-interventions

- None specified

Patients were encouraged to contact the research dietitian if they needed further dietary advice

\begin{tabular}{ll}
\hline Outcomes & - Death \\
- & Transfer to HD \\
- Protein and energy intakes \\
- Potassium intake \\
- Pesphorus intake \\
- Potassium albumin \\
- Phosphate \\
- Body weight \\
- Mid-arm circumference \\
\hline - Funding source: not reported \\
- Additional data: none requested \\
- Trial registration number not provided
\end{tabular}

\section{Risk of bias}

\begin{tabular}{lll}
\hline Bias & Authors' judgement & Support for judgement \\
\hline $\begin{array}{l}\text { Random sequence genera- } \\
\text { tion (selection bias) }\end{array}$ & Low risk & Computer-generated random numbers \\
\hline $\begin{array}{l}\text { Allocation concealment } \\
\text { (selection bias) }\end{array}$ & Unclear risk & Insufficient information to permit judgement \\
\hline
\end{tabular}


Sutton 2007 (Continued)

Blinding of participants and personnel (perfor-

High risk mance bias)

All outcomes
Masking of patients or study personnel not reported in the study report. Masking was unlikely due to the nature of the interventions. "Although the patient information described the purpose of the study, patients were not explicitly told which group they were in."

$\begin{array}{lll}\text { Blinding of outcome as- } & \text { Unclear risk } & \text { Insufficient information to permit judgement } \\ \text { sessment (detection bias) }\end{array}$

Objective outcomes

\begin{tabular}{|c|c|c|}
\hline $\begin{array}{l}\text { Incomplete outcome data } \\
\text { (attrition bias) } \\
\text { All outcomes }\end{array}$ & High risk & $\begin{array}{l}4 / 30 \text { excluded from analysis in treatment group; } 6 / 29 \text { excluded from analysis } \\
\text { in control group }\end{array}$ \\
\hline
\end{tabular}

\begin{tabular}{lll}
\hline $\begin{array}{l}\text { Selective reporting (re- } \\
\text { porting bias) }\end{array}$ & High risk & $\begin{array}{l}\text { No pre-published study protocol. Unclear whether treatment outcomes are re- } \\
\text { ported as planned }\end{array}$ \\
\hline Other bias & Unclear risk & Funding source not reported \\
\hline
\end{tabular}

Teng 2013

\begin{tabular}{ll}
\hline Methods & - Study design: parallel RCT \\
& - Time frame: November 2008 to October 2009 \\
& - Duration: 24 months
\end{tabular}

\section{Participants}

- Country: Taiwan

- Setting: Single centre

- Inclusion criteria: adults; early CKD with a normal to moderately reduced GFR; able to communicate in Mandarin or Taiwanese

- Number: treatment group (80); control group (80)

- Mean age \pm SD (years): treatment group (62.1 \pm 14$)$; control group (65.65 \pm 11.2$)$

- $\operatorname{Sex}(M / F)$ : treatment group (33/19); control group (40/11)

- Baseline characteristics

* Mean body weight $(\mathrm{kg})$ : not reported

* Mean baseline $\mathrm{SCr}(\mu \mathrm{mol} / \mathrm{mL})$ : not reported

* Mean baseline GFR (mL/min): treatment group (53.74 \pm 18.28$)$; control group (49.54 \pm 13.29$)$

* Mean baseline serum albumin $(\mathrm{g} / \mathrm{L})$ : not reported

* Mean baseline calorie intake (kcal): not reported

- Exclusion criteria: co-morbid conditions like heart, lung, neurological, or skeletal muscular diseases that prohibited exercise; psychiatric problems; needed assistance in the basic activities of daily living

- Provided with five targeted interventions were to promote or maintain positive dietary behaviours, and five targeted interventions to promote or maintain positive exercise behaviours. Participants assigned to the treatment group were provided a face-to face counselling and information by the research assistants according to their self-reported stage of change at each visit related to diet and exercise lifestyle behaviours: pre-contemplation, contemplation, preparation, action, or maintenance.

- The Lifestyle Modification Program, aimed at enhancing a patient's motivation-to-change behaviour, provided an opportunity to discuss the reasons why he or she was not able to achieve the set goals and implement lifestyle modification interventions. The goal of the program was to promote the participant's intention with regard to lifestyle modification for slowing kidney disease progression. The targeted treatment group was determined at each clinic visit after the participants had completed the TTM staging inventory for dietary and lifestyle behaviours. The interventions were delivered by registered nurse research assistants who had received $8 \mathrm{hr}$ of theoretical and practical training in the 
Teng 2013 (Continued)

Lifestyle Modification Program and attended weekly debriefing meetings with the research investigators.

Control group

- Received face-to-face standard education by the trained research assistants on healthy eating for proper protein, low-salt, and low-fat diet, and on benefits of regular exercise at least 3 times a week for 20 min per session

Co-interventions

- Not reported

Participants in both groups received a follow-up telephone call to remind them of their appointment 1 month prior to each return clinic visit

\begin{tabular}{ll}
\hline Outcomes & Change in stages of dietary and exercise behaviour \\
& - Health promoting lifestyle profile-II \\
\hline Notes & - Funding source: funded by National Science Council, Taiwan NSC95-2314-B-006-082-MY3. \\
& - Tdditional data: none requested \\
& \\
\hline
\end{tabular}

\section{Risk of bias}

Bias Authors' judgement Support for judgement

$\begin{aligned} & \text { Random sequence genera- } \\ & \text { tion (selection bias) }\end{aligned}$
Unclear risk Insufficient information to permit judgement

\begin{tabular}{|c|c|c|}
\hline $\begin{array}{l}\text { Allocation concealment } \\
\text { (selection bias) }\end{array}$ & Unclear risk & Insufficient information to permit judgement \\
\hline $\begin{array}{l}\text { Blinding of participants } \\
\text { and personnel (perfor- } \\
\text { mance bias) } \\
\text { All outcomes }\end{array}$ & High risk & $\begin{array}{l}\text { Masking of patients or study personnel not reported in the study report. Par- } \\
\text { ticipants were randomised to either lifestyle modification group or standard } \\
\text { care. Therefore, the study was unlikely to be blinded }\end{array}$ \\
\hline $\begin{array}{l}\text { Blinding of outcome as- } \\
\text { sessment (detection bias) } \\
\text { Objective outcomes }\end{array}$ & Unclear risk & $\begin{array}{l}\text { Insufficient information to permit judgement. Parameters measured in this } \\
\text { study were likely to be influenced by knowledge of treatment allocation }\end{array}$ \\
\hline $\begin{array}{l}\text { Incomplete outcome data } \\
\text { (attrition bias) } \\
\text { All outcomes }\end{array}$ & Low risk & $\begin{array}{l}63 \% \text { of participants in control group and } 59 \% \text { of participants in treatment } \\
\text { group completed } 12 \text { months of study. No imbalance between groups }\end{array}$ \\
\hline $\begin{array}{l}\text { Selective reporting (re- } \\
\text { porting bias) }\end{array}$ & High risk & $\begin{array}{l}\text { No pre-published study protocol. Unclear whether treatment outcomes are re- } \\
\text { ported as planned. Clinical outcomes (mortality, ESKD) not provided }\end{array}$ \\
\hline Other bias & Low risk & Study appears free of other biases \\
\hline
\end{tabular}

Tzvetanov 2014

\begin{tabular}{ll}
\hline Methods & - Study design: parallel RCT \\
& - Time frame: not reported \\
& Duration: 12 months
\end{tabular}


Tzvetanov 2014 (Continued)

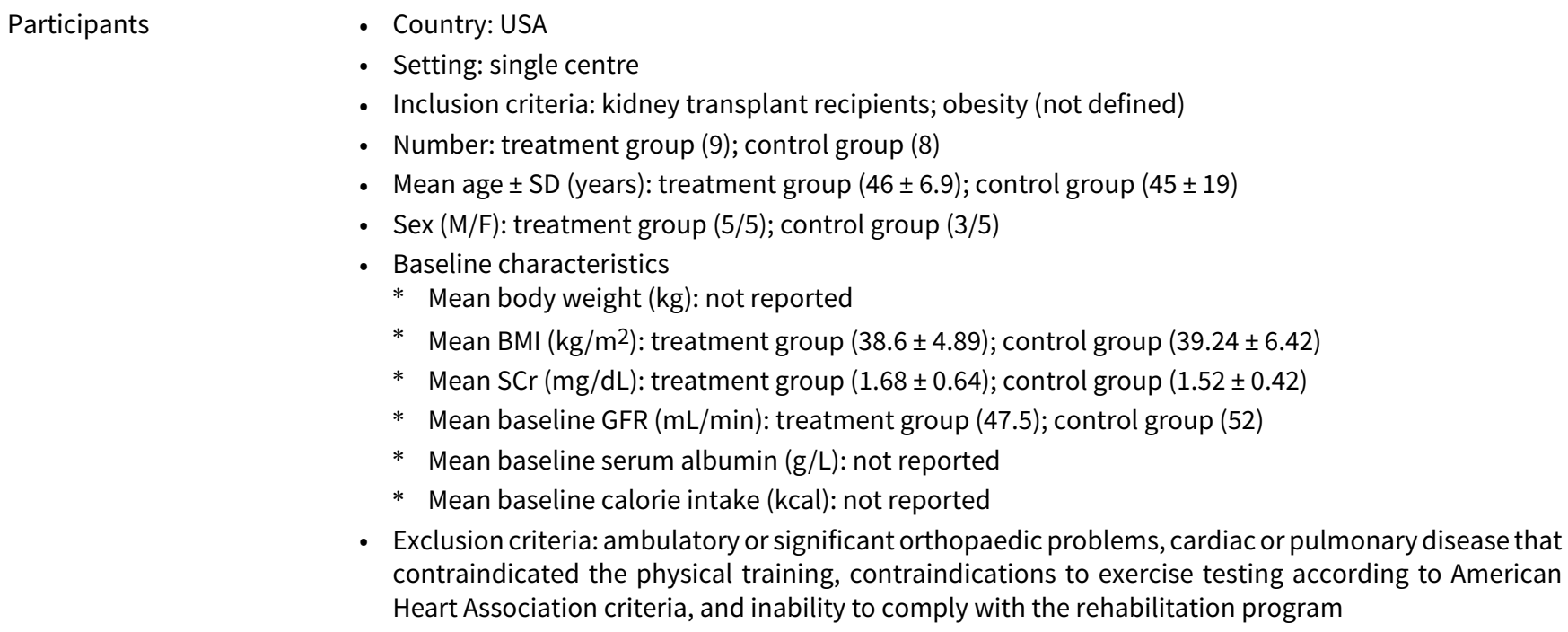

- Exclusion criteria: ambulatory or significant orthopaedic problems, cardiac or pulmonary disease that contraindicated the physical training, contraindications to exercise testing according to American Heart Association criteria, and inability to comply with the rehabilitation program

- Personalised approach for physical rehabilitation (GH method). The "GH' method consisted of individual physical training (one-to-one resistance-based weight training with two 1-hour sessions each week in a private environment. The objective of the exercise protocol was to maximise adherence, improve medical health, reduce pain, improve energy, and enhance emotional wellness and quality of life. Each session had a clearly defined protocol incorporating physical, educational, and psychological aspects. The protocol leveraged 3 main strategies: resistance training; changing thinking and feeling patterns; coaching to make sustainable changes to lifestyle

Control group

- Standard of care for kidney transplant recipients, which included dietary and exercise counselling by the transplant nutritionist at the time of transplantation and additional dietary and exercise counselling by the transplant physicians at post-transplantation clinic visits

\begin{tabular}{ll}
\hline Outcomes & BMI \\
- Total body mass \\
- Body fat percentage \\
- BP Pulse wave velocity \\
- Intimal-medial thickness \\
- eGFR \\
- SCr \\
- Lipids \\
- HbAlc \\
- SF-36 score \\
- Subjective pain assessment \\
- Employment
\end{tabular}

Notes

- Funding source: not reported

- Additional data: none requested

- Trial registration number not provided

\section{Risk of bias}


Tzvetanov 2014 (Continued)
Random sequence genera-
Unclear risk
Insufficient information to permit judgement tion (selection bias)

\begin{tabular}{|c|c|c|}
\hline $\begin{array}{l}\text { Allocation concealment } \\
\text { (selection bias) }\end{array}$ & Unclear risk & $\begin{array}{l}\text { Prepared sealed envelopes containing a card indicated the allocated treat- } \\
\text { ment group. Not reported whether envelopes were opaque or sequentially } \\
\text { numbered }\end{array}$ \\
\hline
\end{tabular}

\begin{tabular}{|c|c|c|}
\hline $\begin{array}{l}\text { Blinding of participants } \\
\text { and personnel (perfor- } \\
\text { mance bias) }\end{array}$ & High risk & $\begin{array}{l}\text { Masking of patients or study personnel not reported in the study report. Par- } \\
\text { ticipants were randomised to either lifestyle modification group or standard } \\
\text { care. Therefore, the study was unlikely to be blinded }\end{array}$ \\
\hline
\end{tabular}

All outcomes

Unclear risk

Insufficient information to permit judgement. Parameters measured in this

Blinding of outcome asstudy were likely to be influenced by knowledge of treatment allocation

Objective outcomes

Incomplete outcome data High risk

(attrition bias)

All outcomes

\begin{tabular}{lll}
\hline $\begin{array}{l}\text { Selective reporting (re- } \\
\text { porting bias) }\end{array}$ & High risk & $\begin{array}{l}\text { No pre-published study protocol. Unclear whether treatment outcomes are re- } \\
\text { ported as planned }\end{array}$ \\
\hline Other bias & Unclear risk & Funding source not reported \\
\hline
\end{tabular}

Only 4 people allocated to the control group attended follow up at 6 months and 2 at 12 months

No pre-published study protocol. Unclear whether treatment outcomes are re-

Funding source not reported

Whittier 1985

\begin{tabular}{|c|c|}
\hline Methods & $\begin{array}{l}\text { - Study design: parallel RCT } \\
\text { - Time frame: not reported } \\
\text { - Duration: } 1 \text { month (28 days) }\end{array}$ \\
\hline Participants & $\begin{array}{l}\text { - Country: USA } \\
\text { - Setting: single centre } \\
\text { - Inclusion criteria: kidney transplant recipients } \\
\text { - Number: treatment group }(6) \text {; control group }(6) \\
\text { - Mean age } \pm \mathrm{SD} \text { (years): not reported } \\
\text { - Sex (M/F): treatment group }(4 / 2) \text {; control group }(5 / 1) \\
\text { - Baseline characteristics } \\
\text { * Mean body weight }(\mathrm{kg}) \text { : treatment group }(71 \pm 5) \text {; control group }(68 \pm 5) \\
\text { * Mean BMI }\left(\mathrm{kg} / \mathrm{m}^{2}\right) \text { : not reported } \\
\text { * Mean } \mathrm{SCr}(\mathrm{mg} / \mathrm{dL}): \text { not reported } \\
\text { * Mean baseline } \mathrm{GFR}(\mathrm{mL} / \text { min): not reported } \\
\text { - Exclusion criteria: > } 55 \text { years; diabetes }\end{array}$ \\
\hline Interventions & $\begin{array}{l}\text { Treatment group } \\
\text { - A general daily diet order was prescribed for all patients; it consisted of } 800 \mathrm{~mL} \text { fluid restriction plus an } \\
\text { amount equal to the urine volume } / \mathrm{d}, 2 \mathrm{~g} \text { sodium, } 80 \mathrm{mEq} \text { potassium, } 800 \text { to } 1200 \mathrm{mg} \text { of calcium, and } 30 \\
\text { calories } / \mathrm{kg} \text {. However, the composition of the diet was determined according to inclusion into either } \\
\text { the experimental or control group. Total calories and content of the diet, in identical proportions, were } \\
\text { adjusted up or down per kilogram to the nearest } 10 \mathrm{~kg} \text { for patients who weighed more or less than } 70 \\
\mathrm{~kg} \text { since the ideal body weight of these patients varied from } 50 \text { to } 90 \mathrm{~kg} \text { prior to transplantation. The }\end{array}$ \\
\hline
\end{tabular}


Whittier 1985 (Continued)

experimental diet (for a $70 \mathrm{~kg}$ person) included 210 grams protein (higher than the control diet), 70 grams carbohydrate (lower than control) and the same amount of fat as the control diet

Control group

- A general daily diet order was prescribed for all patients; it consisted of $800 \mathrm{~mL}$ fluid restriction plus an amount equal to the urine volume/d, 2 g sodium, $80 \mathrm{mEq}$ potassium, 800 to $1200 \mathrm{mg}$ of calcium, and 30 calories $/ \mathrm{kg}$. However, the composition of the diet was determined according to inclusion into either the experimental or control group. Total calories and content of the diet, in identical proportions, were adjusted up or down per $\mathrm{kg}$ to the nearest $10 \mathrm{~kg}$ for patients who weighed more or less than 70 $\mathrm{kg}$ since the ideal body weight of these patients varied from 50 to $90 \mathrm{~kg}$ prior to transplantation. The experimental diet included 70 grams protein (lower than experimental diet), 210 grams carbohydrate (higher than experimental) and the same amount of fat as the experimental diet.

Co-interventions

- Standard immunosuppression and pulse steroids for acute rejection

\begin{tabular}{ll}
\hline - & Nitrogen and electrolyte balance \\
- Energy intake \\
- Protein intake \\
- Sodium and potassium balance \\
- Muscle mass \\
- Glucose tolerance \\
- HbAlc \\
- Acute rejection \\
- BUN \\
- Serum potassium \\
- Funding source: General Clinical Research Center of the University of Missouri-Columbia Medical Cen- \\
- ter, Grant No, RRo0287 \\
- Trial registration number not applicable
\end{tabular}

\section{Risk of bias}

\begin{tabular}{lll}
\hline Bias & Authors' judgement & Support for judgement \\
\hline $\begin{array}{l}\text { Random sequence genera- } \\
\text { tion (selection bias) }\end{array}$ & Unclear risk & Insufficient information to permit judgement \\
\hline $\begin{array}{l}\text { Allocation concealment } \\
\text { (selection bias) }\end{array}$ & Unclear risk & Insufficient information to permit judgement \\
\hline $\begin{array}{l}\text { Blinding of participants } \\
\text { and personnel (perfor- } \\
\text { mance bias) }\end{array}$ & High risk & $\begin{array}{l}\text { Masking of patients or study personnel not reported in the study report. Par- } \\
\text { ticipants were randomised to either in-patient study group or standard care. }\end{array}$ \\
\hline $\begin{array}{l}\text { Blinding of outcome as- } \\
\text { sessment (detection bias) } \\
\text { Objective outcomes }\end{array}$ & Unclear risk & $\begin{array}{l}\text { Therefore, the study was unlikely to be blinded } \\
\text { Insufficient information to permit judgement. Parameters measured in this } \\
\text { study were unlikely to be influenced by knowledge of treatment allocation }\end{array}$ \\
$\begin{array}{l}\text { Incomplete outcome data } \\
\text { All outcomes }\end{array}$ & Unclear risk & $\begin{array}{l}\text { The proportion of people who were randomised and included in final analysis } \\
\text { not reported }\end{array}$ \\
\hline
\end{tabular}


Whittier 1985 (Continued)

Selective reporting (re- High risk No pre-published study protocol. Unclear whether treatment outcomes are reporting bias) ported as planned

Other bias Low risk Study appears free of other biases

Zhou 2011b

\begin{tabular}{ll}
\hline Methods & Study design: parallel RCT \\
& - Time frame: April 2009 to April 2010 \\
& Duration: 6 months
\end{tabular}

\begin{tabular}{|c|c|}
\hline Participants & $\begin{array}{l}\text { - Country: China } \\
\text { - Setting: single centre } \\
\text { - Inclusion criteria: adults } 18 \text { to } 70 \text { years and receiving PD }>3 \text { months } \\
\text { - Number: treatment group }(52) \text {; control group }(50) \\
\text { - Mean age } \pm \mathrm{SD} \text { (years): treatment group }(57.8 \pm 12.8) \text {; control group }(59.9 \pm 13.6) \\
\text { - Sex (M/F): treatment group ( } 38 / 14) \text {; control group }(34 / 16) \\
\text { - Baseline characteristics } \\
* \text { Mean body weight }(\mathrm{kg}) \text { : not reported } \\
* \text { Mean } \mathrm{BMI}\left(\mathrm{kg} / \mathrm{m}^{2}\right) \text { : treatment group }(23.3 \pm 4.5) \text {; control group }(22.8 \pm 6.2) \\
* \text { Mean } \mathrm{SCr}(\mathrm{mg} / \mathrm{dL}) \text { : not reported } \\
* \text { Mean baseline GFR (mL/min): not reported } \\
* \text { Mean baseline calorie intake: not reported }\end{array}$ \\
\hline
\end{tabular}

- Exclusion criteria: aged < 18 or $>70$ years; ready to receive transplantation within 6 months; unable to eat by mouth or receive enteral nutrition; severe infection; malignancy; non-kidney organ dysfunction

- According to the individualized nutrition treatment group regimen developed by dietitians with regard to patients' general condition, nutritional status and characteristics, patients from the study group received treatment group as below: the amount of energy was $125 \mathrm{~kJ} /(\mathrm{kg} \cdot \mathrm{d})$, the amount of proteins was $1.2-1.3 \mathrm{~g} /(\mathrm{kg} \cdot \mathrm{d})$, and the proportion of proteins of high biological value was $70 \%$ to $75 \%$. Oral enteral nutritional supplements were used for those who did not get enough nutrients from food. The volume of water intake was urinary volume at last day plus $500 \mathrm{~mL}$, and the amount of sodium was $3 \mathrm{~g} / \mathrm{d}$. The investigators were informed of the detailed status of nutrient intake weekly in a faceto-face manner. Participants also received psychological support and nurse-led exercise training

Control group

- Routine care

Co-interventions

- None reported

Outcomes

- Nutritional status: malnutrition

- Anthropomorphic data: triceps skin-fold thickness; upper arm circumference; arm muscle circumference; grip strength

- Quality of life: KDTA; SF-36

Notes

- Funding source: not reported

- Additional data: none requested

- Trial registration number: not reported

- Journal article was professionally translated from Chinese to English before data extraction 
Zhou 2011b (Continued)

Risk of bias

\begin{tabular}{|c|c|c|}
\hline Bias & Authors' judgement & Support for judgement \\
\hline $\begin{array}{l}\text { Random sequence genera- } \\
\text { tion (selection bias) }\end{array}$ & Unclear risk & Randomisation table \\
\hline $\begin{array}{l}\text { Allocation concealment } \\
\text { (selection bias) }\end{array}$ & Unclear risk & Insufficient information to permit judgement \\
\hline $\begin{array}{l}\text { Blinding of participants } \\
\text { and personnel (perfor- } \\
\text { mance bias) } \\
\text { All outcomes }\end{array}$ & High risk & $\begin{array}{l}\text { Masking of patients or study personnel not reported in the study report. Par- } \\
\text { ticipants were randomised to either in-patient study group or standard care. } \\
\text { Therefore, the study was unlikely to be blinded }\end{array}$ \\
\hline $\begin{array}{l}\text { Blinding of outcome as- } \\
\text { sessment (detection bias) } \\
\text { Objective outcomes }\end{array}$ & High risk & $\begin{array}{l}\text { Insufficient information to permit judgement. Parameters measured in this } \\
\text { study were likely to be influenced by knowledge of treatment allocation }\end{array}$ \\
\hline $\begin{array}{l}\text { Incomplete outcome data } \\
\text { (attrition bias) } \\
\text { All outcomes }\end{array}$ & Low risk & $2 / 52$ participants in the control group withdrew \\
\hline $\begin{array}{l}\text { Selective reporting (re- } \\
\text { porting bias) }\end{array}$ & High risk & $\begin{array}{l}\text { No pre-published study protocol. Unclear whether treatment outcomes are re- } \\
\text { ported as planned }\end{array}$ \\
\hline Other bias & Unclear risk & Funding source(s) not reported \\
\hline
\end{tabular}

BMI - body mass index; BP - blood pressure; BUN - blood urea nitrogen; CKD - chronic kidney disease; CR-LIPE - carbohydrate-restricted, low-iron, polyphenol enriched; CRP - C-reactive protein; DKD - diabetic kidney disease; DBP - diastolic blood pressure; ESKD - end-stage kidney disease; (e)GFR - (estimated) glomerular filtration rate; Hb - haemoglobin; HbA1c - glycolated Hb; HD - haemodialysis; HDL - high density lipoprotein; HPF - high power field; KDTA - ; LDL - low density lipoprotein; M/F - male/female; PD - peritoneal dialysis; RBC - red blood cells; RCT - randomised controlled trial; SBP - systolic blood pressure; $\mathrm{SCr}$ - serum creatinine; SD - standard deviation; $\mathrm{TCO}_{2}$ - total carbon dioxide

Characteristics of excluded studies [ordered by study ID]

\begin{tabular}{ll}
\hline Study & Reason for exclusion \\
\hline Parillo 1988 & $\begin{array}{l}\text { Short duration ( } 2 \text { isoenergetic diets, composed exclusively of natural foods, were given to patients } \\
\text { in a random order for periods of } 10 \text { consecutive days) }\end{array}$ \\
\hline
\end{tabular}

Characteristics of ongoing studies [ordered by study ID]

INTENT Study 2014

\begin{tabular}{ll}
\hline Trial name or title & $\begin{array}{l}\text { The INTENT trial: The effect of intensive nutrition interventions on weight gain after kidney trans- } \\
\text { plantation - a randomised controlled trial }\end{array}$ \\
\hline Methods & RCT \\
\hline Participants & $\begin{array}{l}\text { Adult kidney transplant recipients, aged }>18 \text { years, who reside and undergo transplant surgery } \\
\text { in the Auckland region }\end{array}$ \\
- Willing to participate in all study procedures for duration of follow-up
\end{tabular}


- Written informed consent

- Stable graft function (as determined by the treating Nephrologist)

Interventions
Treatment group

- Intensive programme over 12 months of nutrition assessment, education and advice from a specialist renal dietitian, commencing in the first month after kidney transplantation. This is in addition to standard post kidney transplant care (see control treatment description). Patients allocated to the intensive nutrition group will see a dietitian fortnightly for the first 3 months post-transplant, monthly from 4 to 6 months, and bi-monthly until 12 months (i.e. a total of 12 visits). These visits will last between 30 min and 1 hour on each occasion. Nutrition assessment and education will include regular reviews of dietary intake and weight/anthropometry, and advice focusing on:

* Energy/caloric intake at an appropriate level to achieve a healthy weight and/or weight loss if overweight or obese

* Protein intake to prevent loss of lean muscle mass, i.e. 1.3 to $1.5 \mathrm{~g} / \mathrm{kg} / \mathrm{d}$ in the early period, followed by recommended daily intake of protein for the general population of body weight for males/females for long term stable period

* Fat intake to ensure total energy from fat $<30 \%$ to $35 \%$; with saturated fat and trans fatty acids $<8 \%$

* Carbohydrate intake to ensure adequate fibre intake, low glycaemic index foods

* Dietary calcium and ensure vitamin D supplementation use if required

* Food safety to ensure dietary requirements are met while food safety precautions are followed

* Tailored advice regarding physical activity and exercise, including consultation with an exercise physiologist (approximately 30 minutes at 8 weeks, 12 months and 6 months post-transplant)

- Adherence to the intervention among participants randomised to this group will be determined using the following measures:

* 3-Day food diary: to assess change in dietary habits and adherence to change

* Motivational assessment rulers: to assess motivation to change and elicit change (Miller/Rollnick tools)

* Patient centred goals: assess if achieved individualised goals

* Review patient action plans: review of action steps taken

* Patient self-goal rating scale based on goal attainment scaling (GAS)

Control group

- Standard care post kidney transplant, including all routine medical and surgical care, including immunosuppression, monitoring and prophylaxis of infection.

Outcomes

Primary outcome

- Change in weight $(\mathrm{kg})$ between baseline and 6 months after kidney transplant

Secondary outcomes

- Change in weight and anthropometry measures post-transplant

* Weight $(\mathrm{kg})$

* $\operatorname{BMI}\left(\mathrm{kg} / \mathrm{m}^{2}\right)$

* Waist-hip circumference ratio

* Seated blood pressure

* Mid arm circumference

* Skin fold thickness 
- Change in body composition parameters post-transplant:

* Deuterium measurement analysis to determine total body water

* Dual energy X-ray absorptiometry (DEXA) to determine bone mass and fat mass

* In vivo neutron activation analysis to determine total body protein

* Total body potassium analysis to assess body cell mass

* Bioelectrical impedance as surrogate measure of total body water, extracellular water, fat mass and lean body mass

- Change in biochemical measures post-transplant:

* SCr, full blood count, electrolytes, calcium, phosphate and liver enzymes (non-blinded)

* Immunosuppression drug levels (non-blinded)

* Fasting glucose

* Fasting insulin and determination of homeostatic model assessment index of insulin resistance (HOMA)

* HbAlc

* Serum cholesterol and triglycerides

- Level of physical activity and physical functional capacity post-transplant:

* Physical activity questionnaire

* Six metre gait assessment (maximum walking speed over a 6 metre distance)

* Hand grip strength (dynamometry)

* Sit to stand to sit test (lower extremity strength)

- Quality of life as measured using the (short-form 36 (SF-36) questionnaire

- Adherence to dietary advice post-transplant will be assessed in the intensive intervention group using the following measures:

* 3-Day food diary: to assess change in dietary habits and adherence to change

* Motivational assessment rulers: to assess motivation to change and elicit change (Miller/Rollnick tools)

* Patient centred goals: assess if achieved individualised goals

* Review patient action plans: review of action steps taken

* Patient self-goal rating scale based on goal attainment scaling (GAS)

- Validity of bio-electrical impedance assessment as compared with gold standard body composition analysis in kidney transplant recipients

- Cost-effectiveness analysis of intensive nutrition interventions versus standard of care to reduce weight gain after kidney transplantation

- The difference in $\mathrm{HbA1}$ c between the groups will be used to determine the feasibility of undertaking a larger study of nutrition interventions to improving glucose tolerance and reduce new-onset diabetes after transplant (NODAT).

Starting date

Contact information
$03 / 03 / 2014$

\section{Dr Michael Collins}

Department of Renal Medicine

Auckland City Hospital

Private Bag 92024

Auckland New Zealand Phone+6493797440 Fax+6493074987 Email michael.collins@adhb.govt.nz

\section{DATA AND ANALYSES}


Comparison 1. Dietary intervention versus control

\begin{tabular}{|c|c|c|c|c|}
\hline $\begin{array}{l}\text { Outcome or subgroup } \\
\text { title }\end{array}$ & No. of studies & $\begin{array}{l}\text { No. of partici- } \\
\text { pants }\end{array}$ & Statistical method & Effect size \\
\hline 1 All-cause mortality & 5 & & Risk Ratio (IV, Random, 95\% CI) & Subtotals only \\
\hline 1.1 Dietary counselling & 4 & 371 & Risk Ratio (IV, Random, 95\% CI) & $1.59[0.60,4.21]$ \\
\hline 1.2 CR-LIPE & 1 & 170 & Risk Ratio (IV, Random, 95\% CI) & $0.50[0.22,1.12]$ \\
\hline $\begin{array}{l}2 \text { Cardiovascular mortal- } \\
\text { ity }\end{array}$ & 1 & & Risk Ratio (IV, Random, 95\% Cl) & Totals not selected \\
\hline 2.1 Dietary counselling & 1 & & Risk Ratio (IV, Random, 95\% Cl) & $0.0[0.0,0.0]$ \\
\hline $\begin{array}{l}3 \text { Health-related quality } \\
\text { of life (SF-36) score }\end{array}$ & 2 & & Mean Difference (IV, Random, 95\% CI) & Subtotals only \\
\hline 3.1 Dietary counselling & 2 & 119 & Mean Difference (IV, Random, 95\% Cl) & $11.46[7.73,15.18]$ \\
\hline $\begin{array}{l}4 \text { End-stage kidney dis- } \\
\text { ease }\end{array}$ & 2 & 232 & Risk Ratio (M-H, Random, 95\% Cl) & $0.53[0.26,1.07]$ \\
\hline 4.1 Dietary counselling & 1 & 62 & Risk Ratio (M-H, Random, 95\% Cl) & $0.94[0.06,14.33]$ \\
\hline 4.2 CR-LIPE & 1 & 170 & Risk Ratio (M-H, Random, 95\% Cl) & $0.51[0.25,1.05]$ \\
\hline $\begin{array}{l}5 \text { Doubling of serum cre- } \\
\text { atinine }\end{array}$ & 1 & & Risk Ratio (M-H, Random, 95\% Cl) & Totals not selected \\
\hline 5.1 CR-LIPE & 1 & & Risk Ratio (M-H, Random, 95\% Cl) & $0.0[0.0,0.0]$ \\
\hline 6 Employment & 1 & & Risk Ratio (M-H, Random, 95\% Cl) & Totals not selected \\
\hline 6.1 Dietary counselling & 1 & & Risk Ratio (M-H, Random, 95\% Cl) & $0.0[0.0,0.0]$ \\
\hline 7 Dietary adherence & 1 & & Risk Ratio (M-H, Random, 95\% Cl) & Totals not selected \\
\hline 7.1 Dietary counselling & 1 & & Risk Ratio (M-H, Random, 95\% Cl) & $0.0[0.0,0.0]$ \\
\hline 8 Worsening nutrition & 2 & & Risk Ratio (IV, Random, 95\% CI) & Subtotals only \\
\hline 8.1 Dietary counselling & 2 & 230 & Risk Ratio (IV, Random, 95\% CI) & $0.40[0.05,3.37]$ \\
\hline 9 eGFR $\left[\mathrm{mL} / \mathrm{min} / 1.73 \mathrm{~m}^{2}\right]$ & 5 & 219 & $\begin{array}{l}\text { Std. Mean Difference (IV, Random, 95\% } \\
\text { CI) }\end{array}$ & $1.08[0.20,1.97]$ \\
\hline 9.1 Dietary counselling & 3 & 107 & $\begin{array}{l}\text { Std. Mean Difference (IV, Random, 95\% } \\
\mathrm{CI})\end{array}$ & $1.41[-0.40,3.23]$ \\
\hline 9.2 Mediterranean & 1 & 40 & $\begin{array}{l}\text { Std. Mean Difference (IV, Random, 95\% } \\
\mathrm{CI} \text { ) }\end{array}$ & $0.23[-0.39,0.85]$ \\
\hline 9.3 Fruits and vegetables & 1 & 72 & $\begin{array}{l}\text { Std. Mean Difference (IV, Random, 95\% } \\
\text { CI) }\end{array}$ & $1.14[0.64,1.64]$ \\
\hline 10 Serum creatinine & 3 & 112 & Mean Difference (IV, Random, 95\% Cl) & $0.83[-16.57,18.23]$ \\
\hline
\end{tabular}




\begin{tabular}{|c|c|c|c|c|}
\hline $\begin{array}{l}\text { Outcome or subgroup } \\
\text { title }\end{array}$ & No. of studies & $\begin{array}{l}\text { No. of partici- } \\
\text { pants }\end{array}$ & Statistical method & Effect size \\
\hline 10.1 Dietary counselling & 2 & 72 & Mean Difference (IV, Random, 95\% CI) & $1.79[-24.47,28.05]$ \\
\hline 10.2 Mediterranean & 1 & 40 & Mean Difference (IV, Random, 95\% CI) & $-1.0[-26.17,24.17]$ \\
\hline $\begin{array}{l}11 \text { Systolic blood pres- } \\
\text { sure }\end{array}$ & 3 & 167 & Mean Difference (IV, Random, 95\% CI) & $-9.26[-13.48,-5.04]$ \\
\hline 11.1 Dietary counselling & 2 & 95 & Mean Difference (IV, Random, 95\% CI) & $-11.83[-13.67,-9.98]$ \\
\hline $\begin{array}{l}11.2 \text { Fruits and vegeta- } \\
\text { bles }\end{array}$ & 1 & 72 & Mean Difference (IV, Random, 95\% CI) & $-7.10[-9.60,-4.60]$ \\
\hline $\begin{array}{l}12 \text { Diastolic blood pres- } \\
\text { sure }\end{array}$ & 2 & & Mean Difference (IV, Random, 95\% Cl) & Subtotals only \\
\hline 12.1 Dietary counselling & 2 & 95 & Mean Difference (IV, Random, 95\% CI) & $-8.95[-10.69,-7.21]$ \\
\hline 13 Energy intake & 6 & & $\begin{array}{l}\text { Std. Mean Difference (IV, Random, 95\% } \\
\mathrm{Cl} \text { ) }\end{array}$ & Subtotals only \\
\hline 13.1 Dietary counselling & 4 & 340 & $\begin{array}{l}\text { Std. Mean Difference (IV, Random, 95\% } \\
\mathrm{CI} \text { ) }\end{array}$ & $1.54[-0.87,3.95]$ \\
\hline 13.2 Mediterranean diet & 1 & 40 & $\begin{array}{l}\text { Std. Mean Difference (IV, Random, 95\% } \\
\mathrm{Cl} \text { ) }\end{array}$ & $1.86[1.11,2.61]$ \\
\hline $\begin{array}{l}\text { 13.3 High nitrogen/low } \\
\text { carbohydrate }\end{array}$ & 1 & 12 & $\begin{array}{l}\text { Std. Mean Difference (IV, Random, 95\% } \\
\mathrm{Cl} \text { ) }\end{array}$ & $-0.65[-1.82,0.53]$ \\
\hline 14 Body weight & 6 & 454 & Mean Difference (IV, Random, 95\% CI) & $-0.44[-1.46,0.58]$ \\
\hline 14.1 Dietary counselling & 3 & 200 & Mean Difference (IV, Random, 95\% Cl) & $-0.20[-1.93,1.53]$ \\
\hline $\begin{array}{l}14.2 \text { Fruits and vegeta- } \\
\text { bles }\end{array}$ & 1 & 72 & Mean Difference (IV, Random, 95\% Cl) & $-1.0[-3.57,1.57]$ \\
\hline 14.3 CR-LIPE & 1 & 170 & Mean Difference (IV, Random, 95\% Cl) & $-2.0[-6.22,2.22]$ \\
\hline $\begin{array}{l}\text { 14.4 High nitrogen/low } \\
\text { carbohydrate }\end{array}$ & 1 & 12 & Mean Difference (IV, Random, 95\% Cl) & $3.0[-2.66,8.66]$ \\
\hline $15 \mathrm{BMI}$ & 2 & & Mean Difference (IV, Random, 95\% CI) & Subtotals only \\
\hline 15.1 Dietary counselling & 2 & 119 & Mean Difference (IV, Random, 95\% Cl) & $-1.70[-5.23,1.82]$ \\
\hline 16 Waist-hip ratio & 1 & & Mean Difference (IV, Random, 95\% CI) & Totals not selected \\
\hline 16.1 Dietary counselling & 1 & & Mean Difference (IV, Random, 95\% Cl) & $0.0[0.0,0.0]$ \\
\hline $\begin{array}{l}17 \text { Waist circumference, } \\
\mathrm{cm}\end{array}$ & 1 & & Mean Difference (IV, Random, 95\% Cl) & Totals not selected \\
\hline 17.1 Dietary counselling & 1 & & Mean Difference (IV, Random, 95\% CI) & $0.0[0.0,0.0]$ \\
\hline 18 Arm circumference & 2 & & Mean Difference (IV, Random, 95\% Cl) & Subtotals only \\
\hline
\end{tabular}




\begin{tabular}{llllll}
\hline $\begin{array}{l}\text { Outcome or subgroup } \\
\text { title }\end{array}$ & No. of studies & $\begin{array}{l}\text { No. of partici- } \\
\text { pants }\end{array}$ & Statistical method & Effect size \\
\hline 18.1 Dietary counselling & 2 & 149 & Mean Difference (IV, Random, 95\% Cl) & $0.37[-0.39,1.12]$ \\
\hline 19 Serum albumin & 6 & 541 & Mean Difference (IV, Random, 95\% Cl) & $0.16[0.07,0.24]$ \\
\hline 19.1 Dietary counselling & 4 & 331 & Mean Difference (IV, Random, 95\% Cl) & $0.15[0.14,0.16]$ \\
\hline 19.2 Mediterranean & 1 & 40 & Mean Difference (IV, Random, 95\% Cl) & $0.60[0.11,1.09]$ \\
\hline 19.3 CR-LIPE & 1 & 170 & Mean Difference (IV, Random, 95\% Cl) & $0.0[-0.20,0.20]$ \\
\hline 20 Serum LDL cholesterol & 2 & Mean Difference (IV, Random, 95\% Cl) & Totals not selected \\
\hline 20.1 Mediterranean diet & 1 & Mean Difference (IV, Random, 95\% Cl) & $0.0[0.0,0.0]$ \\
\hline 20.2 CR-LIPE & 1 & Mean Difference (IV, Random, 95\% Cl) & $0.0[0.0,0.0]$ \\
\hline
\end{tabular}

Analysis 1.1. Comparison 1 Dietary intervention versus control, Outcome 1 All-cause mortality.

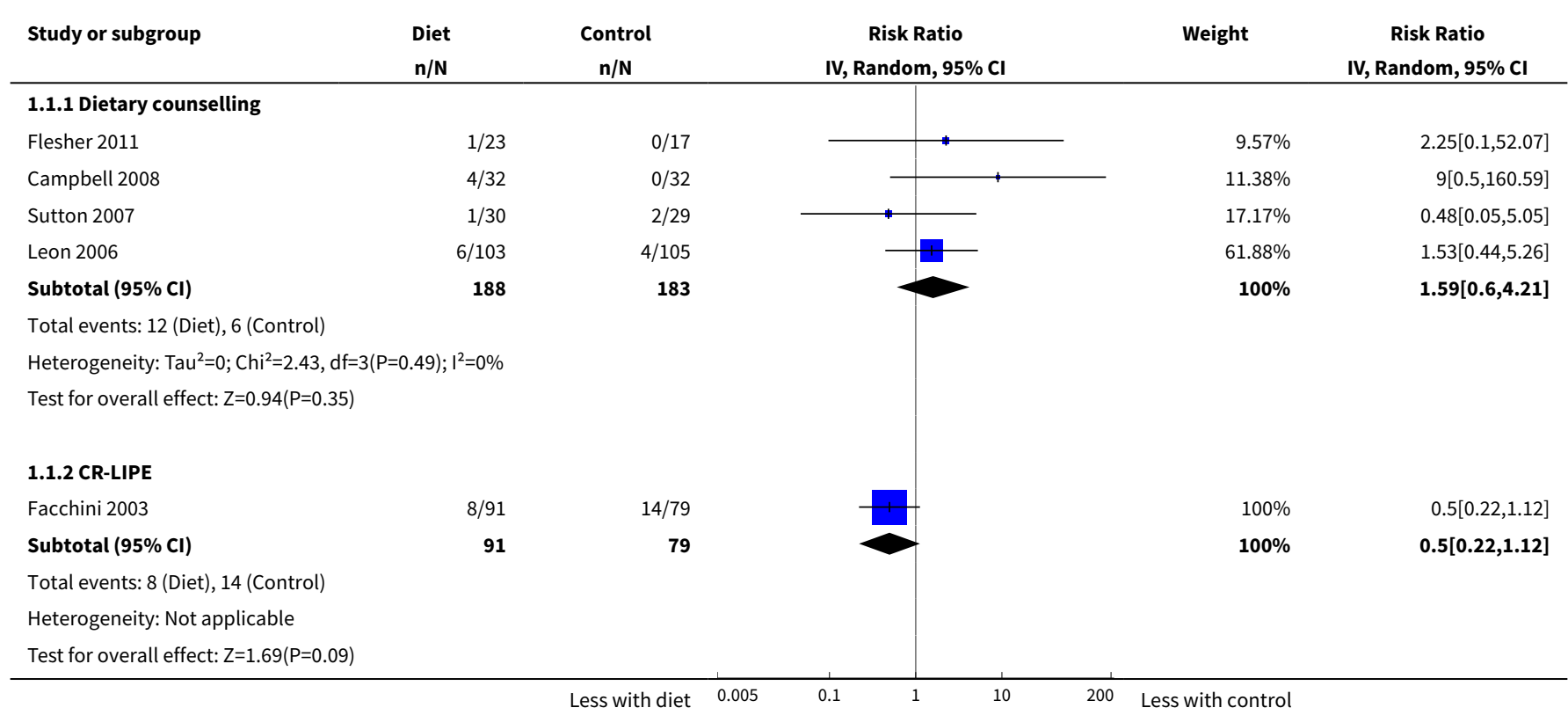

Analysis 1.2. Comparison 1 Dietary intervention versus control, Outcome 2 Cardiovascular mortality.

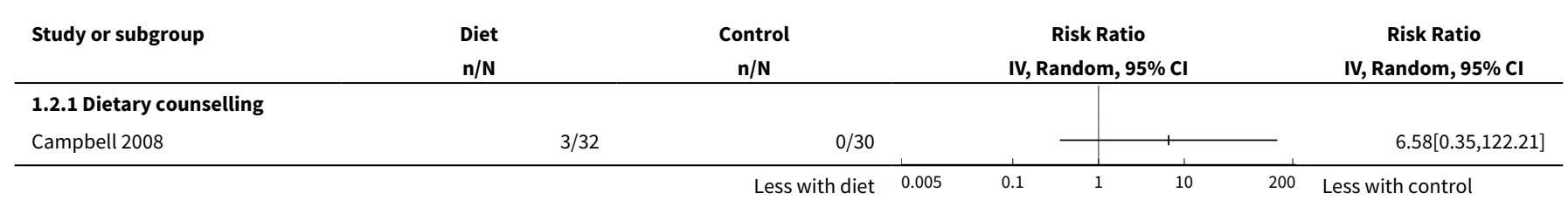


Analysis 1.3. Comparison 1 Dietary intervention versus control, Outcome 3 Health-related quality of life (SF-36) score.

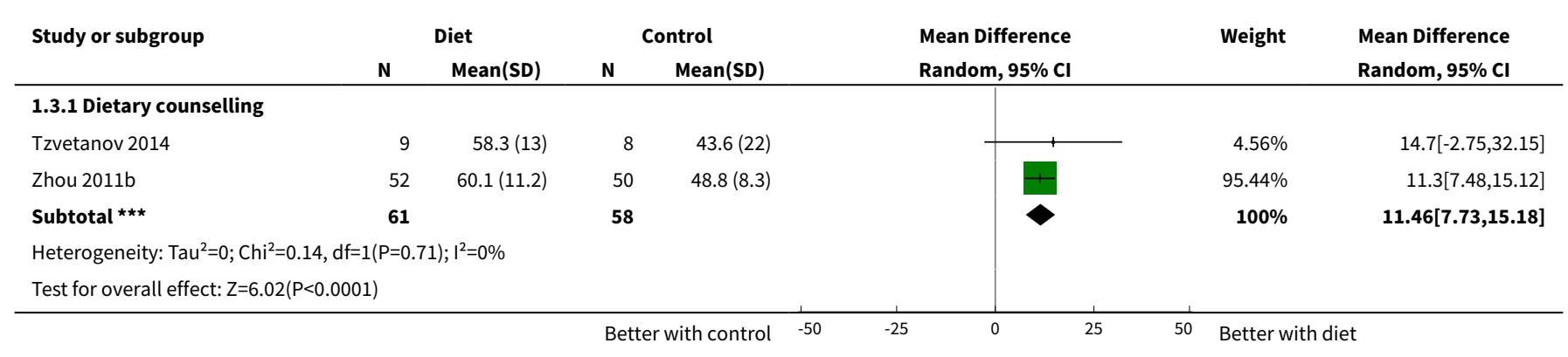

Analysis 1.4. Comparison 1 Dietary intervention versus control, Outcome 4 End-stage kidney disease.

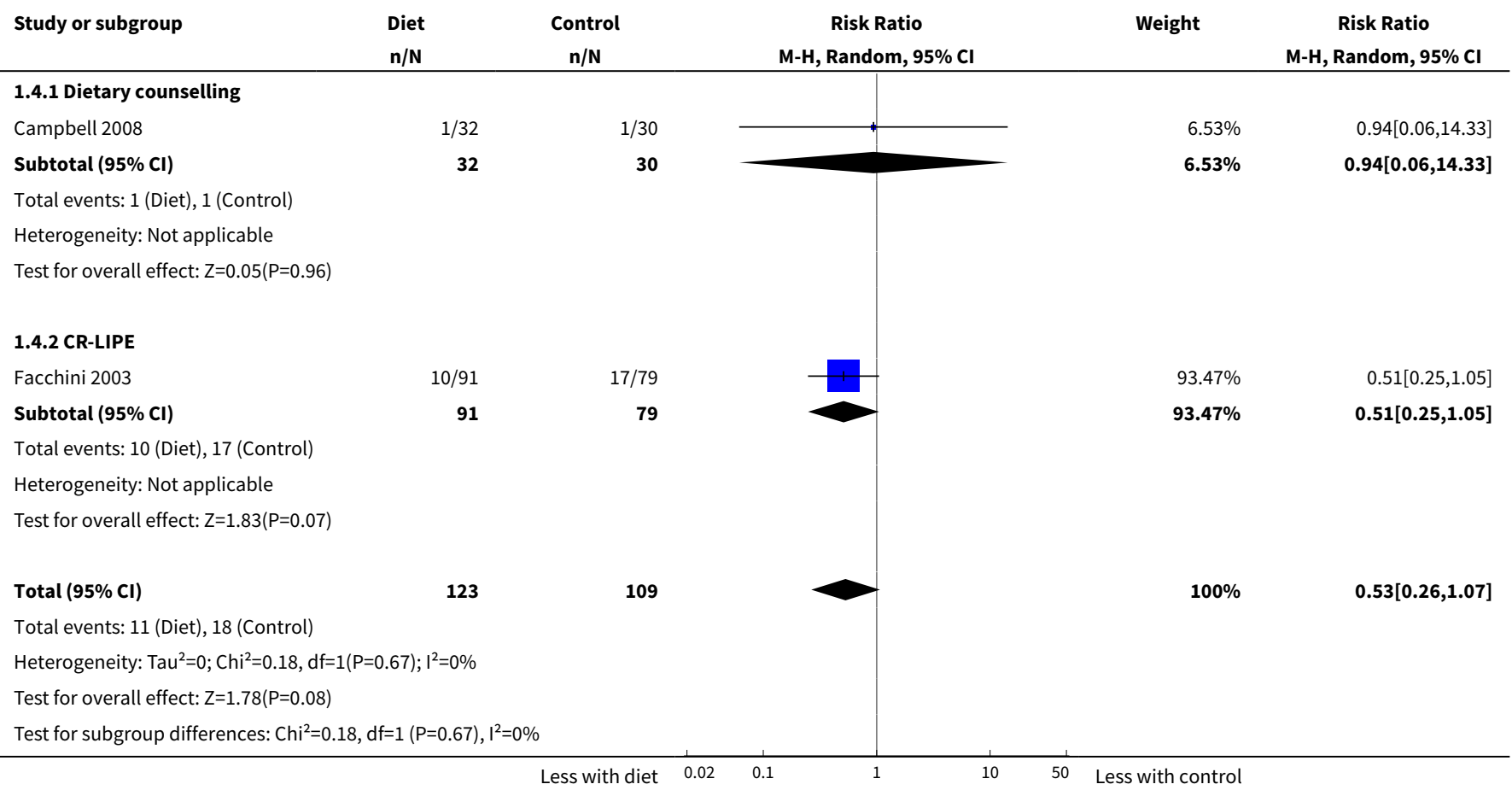

Analysis 1.5. Comparison 1 Dietary intervention versus control, Outcome 5 Doubling of serum creatinine.

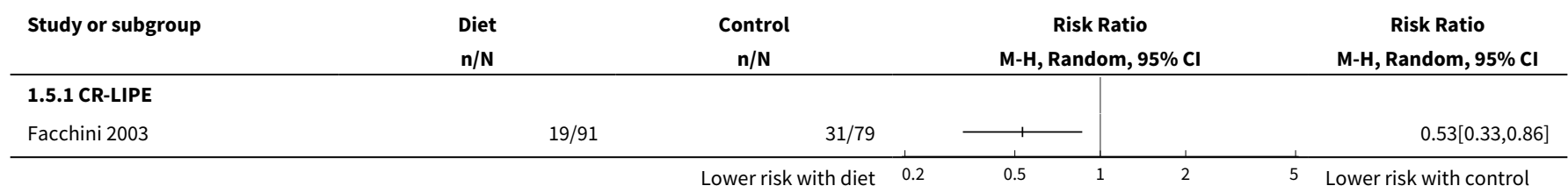


Analysis 1.6. Comparison 1 Dietary intervention versus control, Outcome 6 Employment.

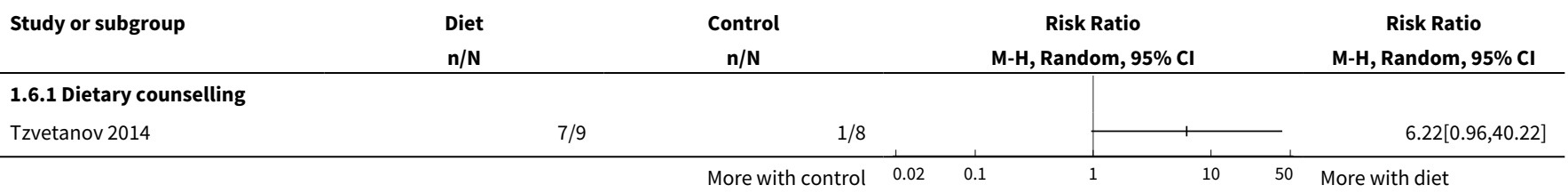

Analysis 1.7. Comparison 1 Dietary intervention versus control, Outcome 7 Dietary adherence.

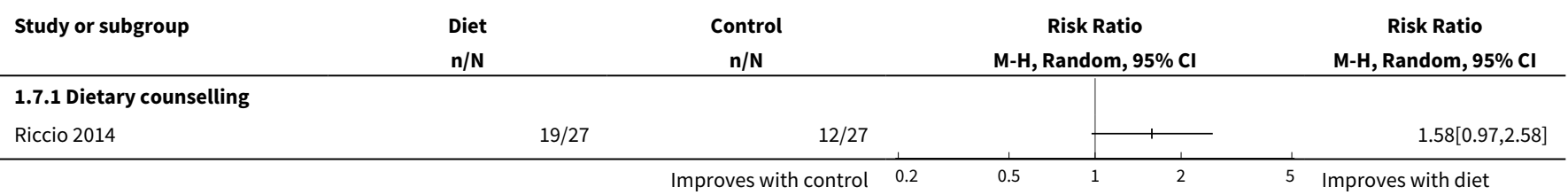

Analysis 1.8. Comparison 1 Dietary intervention versus control, Outcome 8 Worsening nutrition.

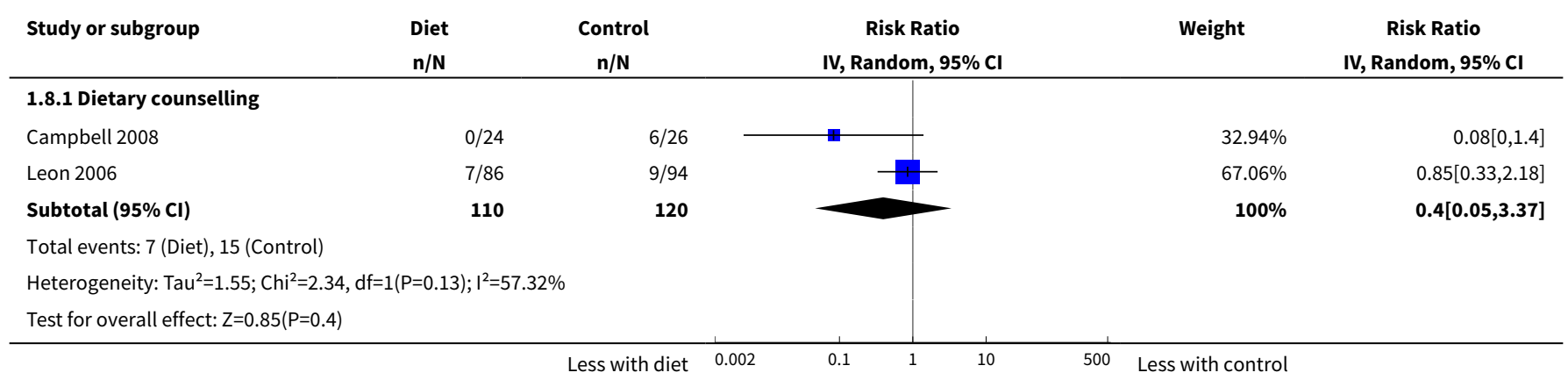

Analysis 1.9. Comparison 1 Dietary intervention versus control, Outcome 9 eGFR [mL/min/1.73 $\left.\mathrm{m}^{2}\right]$.

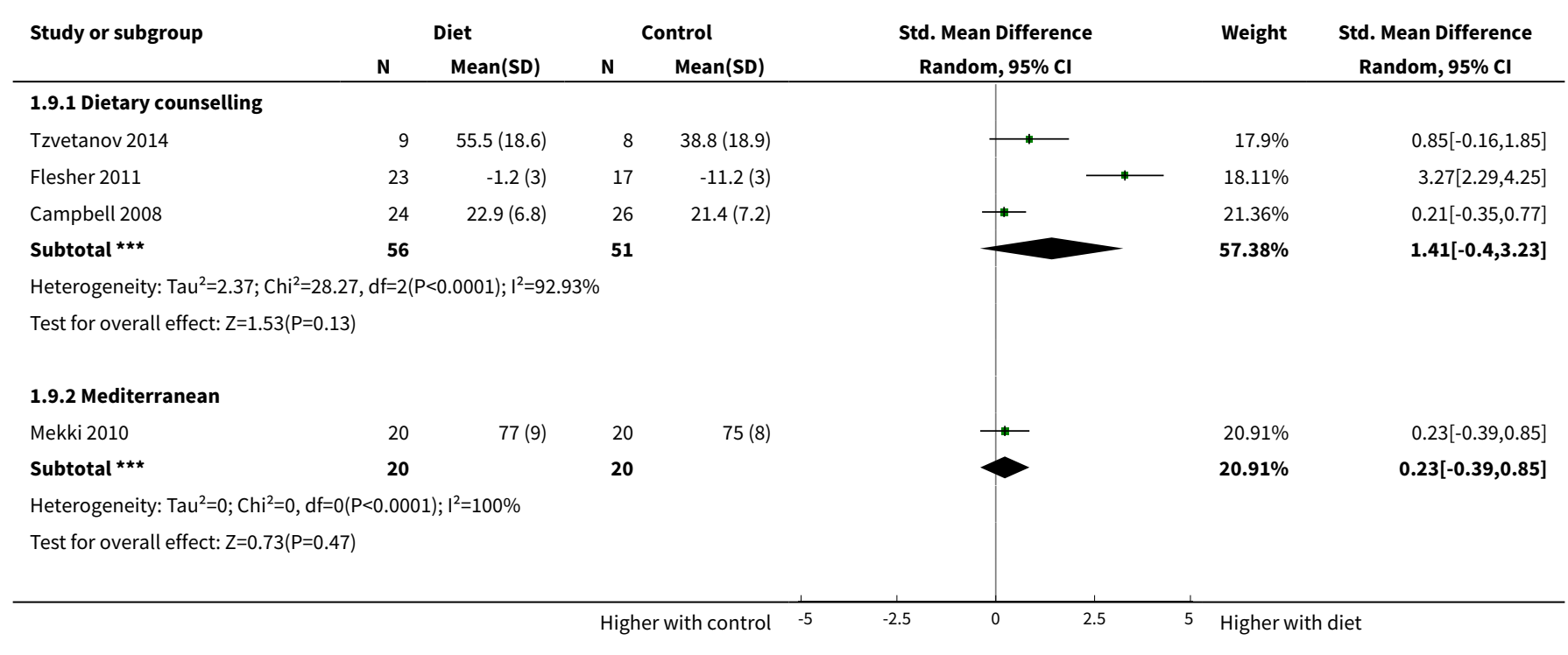




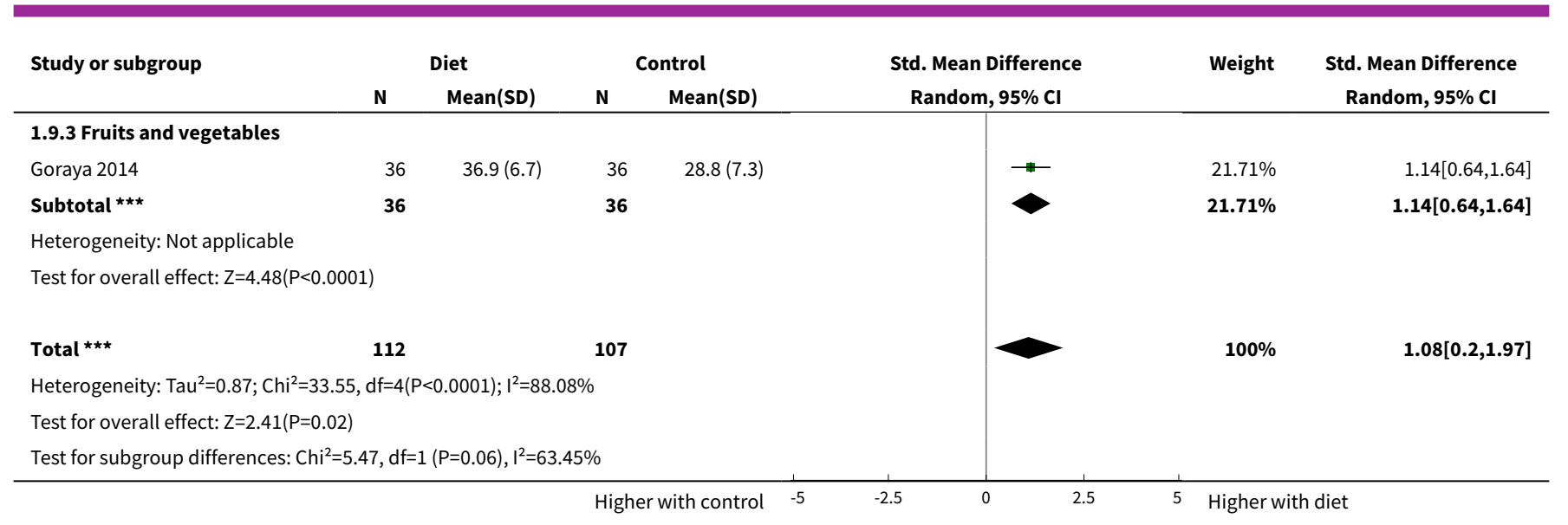

Analysis 1.10. Comparison 1 Dietary intervention versus control, Outcome 10 Serum creatinine.

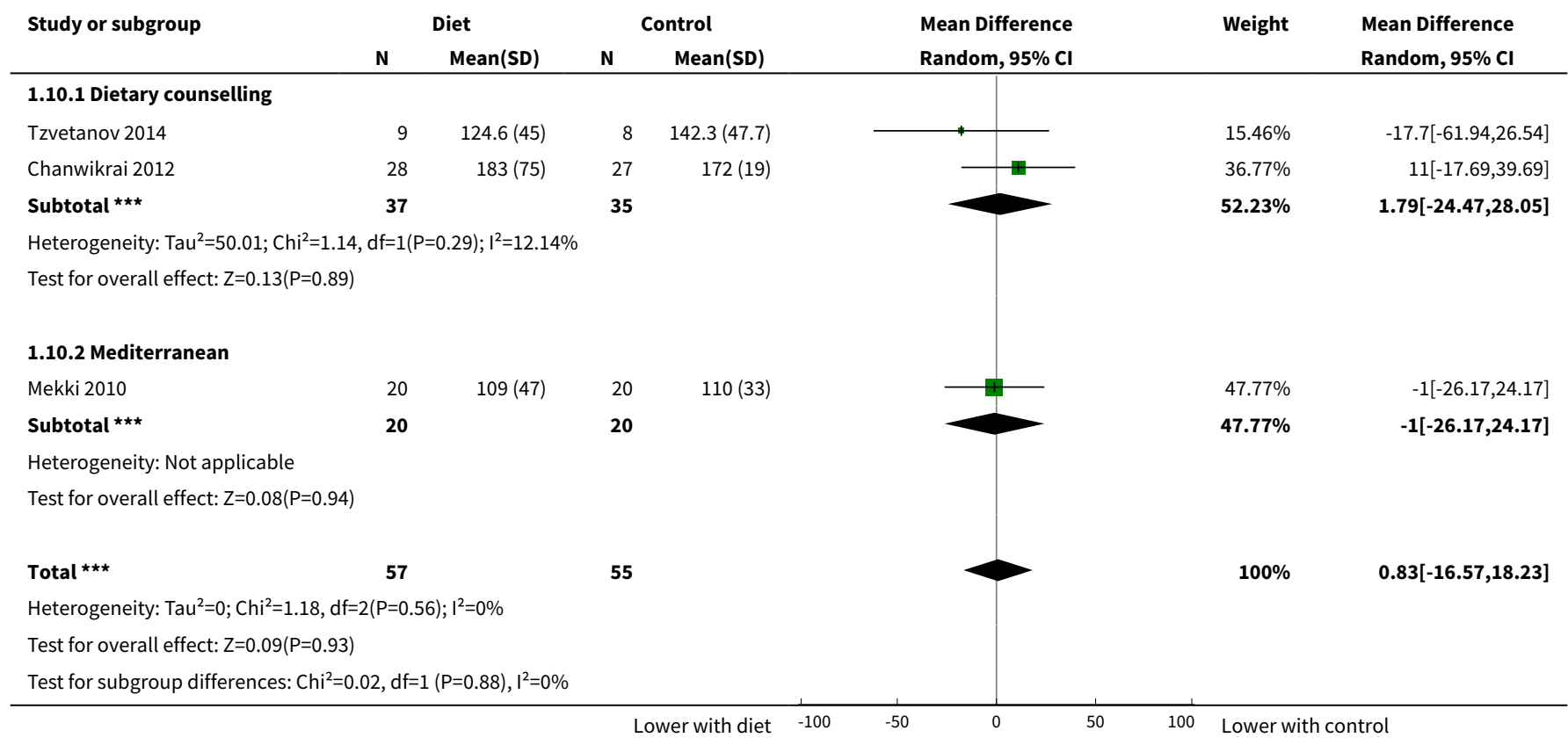

Analysis 1.11. Comparison 1 Dietary intervention versus control, Outcome 11 Systolic blood pressure.

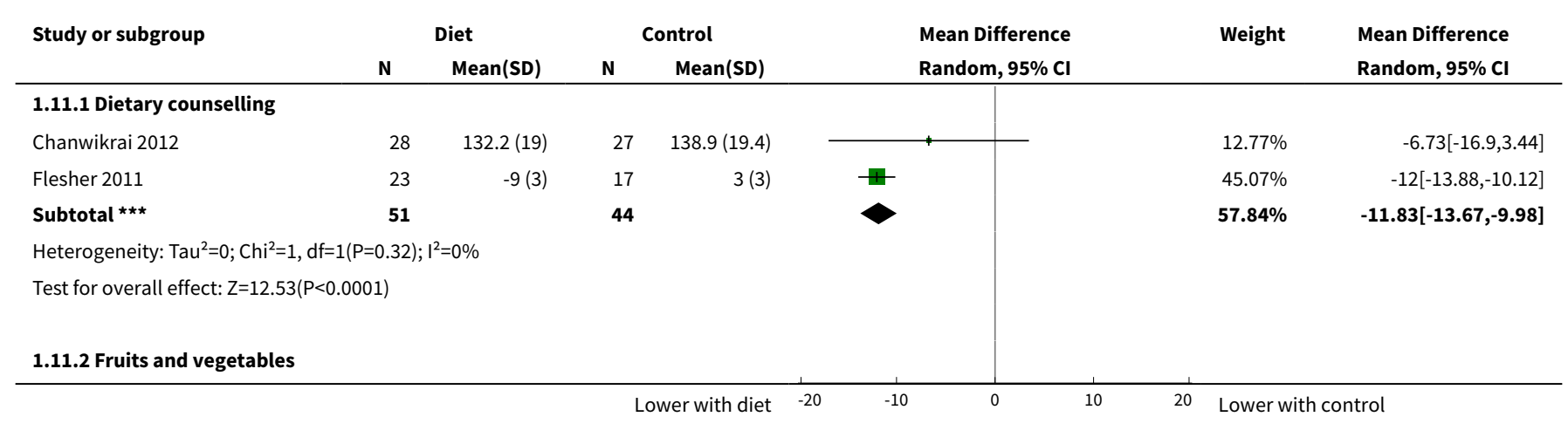




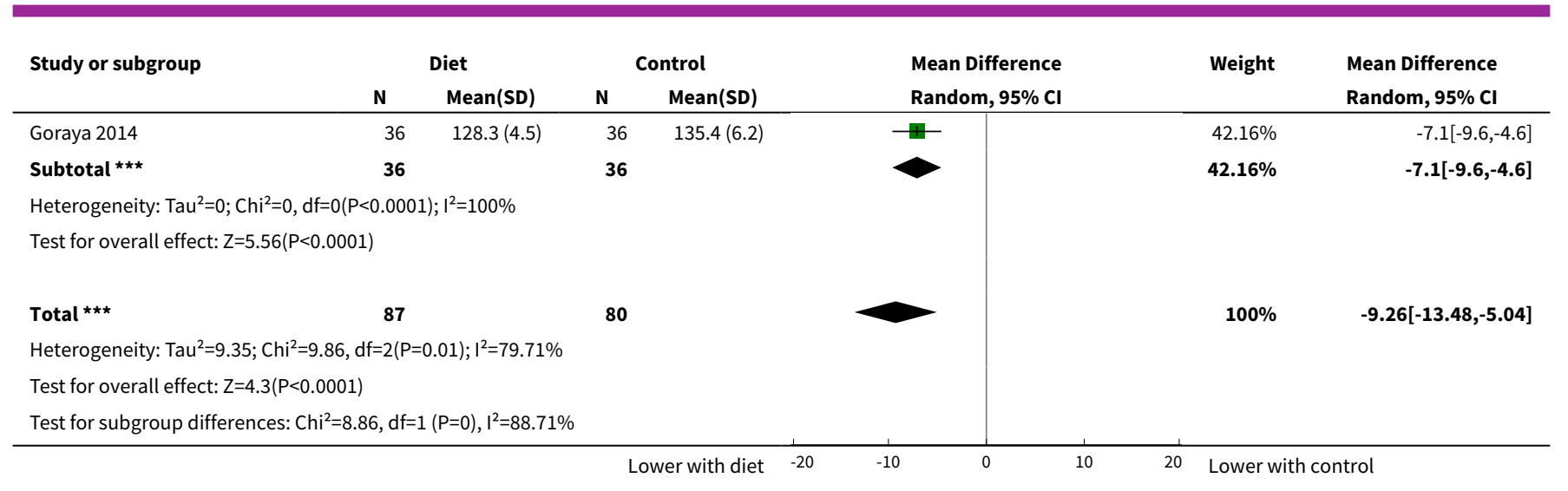

Analysis 1.12. Comparison 1 Dietary intervention versus control, Outcome 12 Diastolic blood pressure.

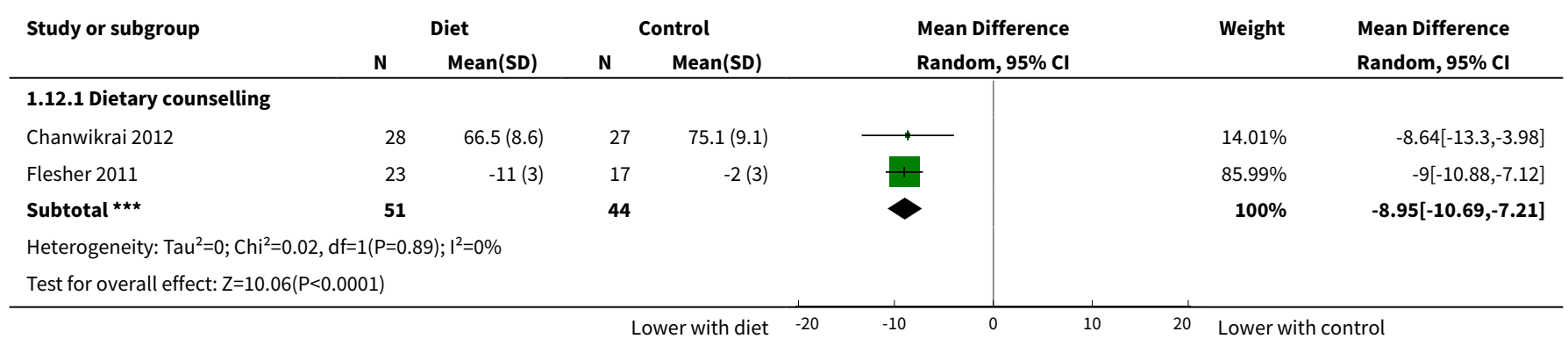

\section{Analysis 1.13. Comparison 1 Dietary intervention versus control, Outcome 13 Energy intake.}

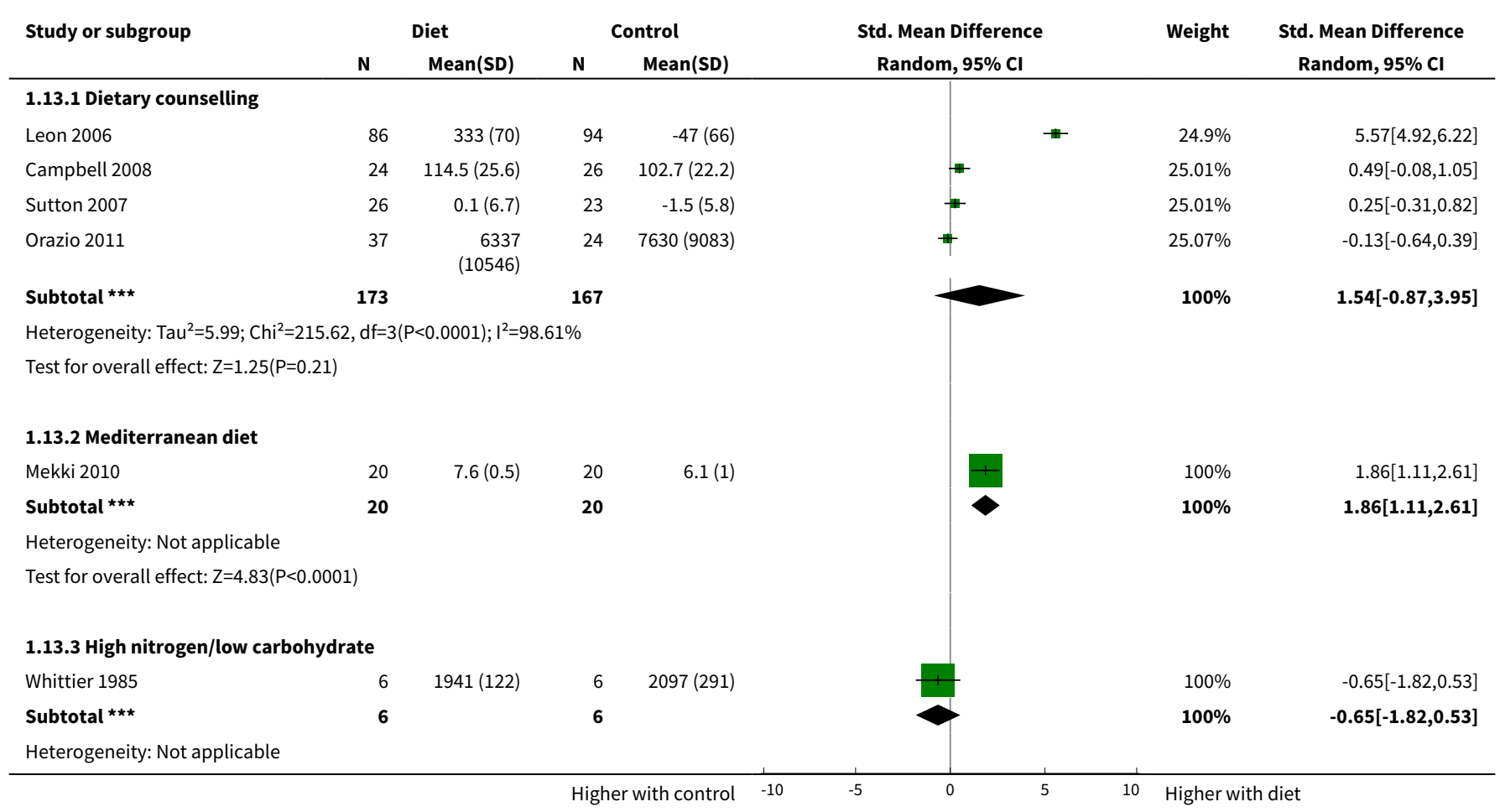




\begin{tabular}{|c|c|c|c|c|c|c|}
\hline \multirow[t]{2}{*}{ Study or subgroup } & Diet & Control & & \multirow{2}{*}{$\begin{array}{c}\text { Std. Mean Difference } \\
\text { Random, } 95 \% \mathrm{Cl}\end{array}$} & \multirow[t]{2}{*}{ Weight } & \multirow{2}{*}{$\begin{array}{c}\text { Std. Mean Difference } \\
\text { Random, } 95 \% \mathrm{Cl}\end{array}$} \\
\hline & Mean(SD) & Mean(SD) & & & & \\
\hline \multicolumn{7}{|l|}{ Test for overall effect: $Z=1.08(P=0.28)$} \\
\hline \multicolumn{7}{|c|}{ Test for subgroup differences: $\mathrm{Chi}^{2}=12.48, \mathrm{df}=1(\mathrm{P}=0), \mathrm{I}^{2}=83.97 \%$} \\
\hline
\end{tabular}

\section{Analysis 1.14. Comparison 1 Dietary intervention versus control, Outcome 14 Body weight.}

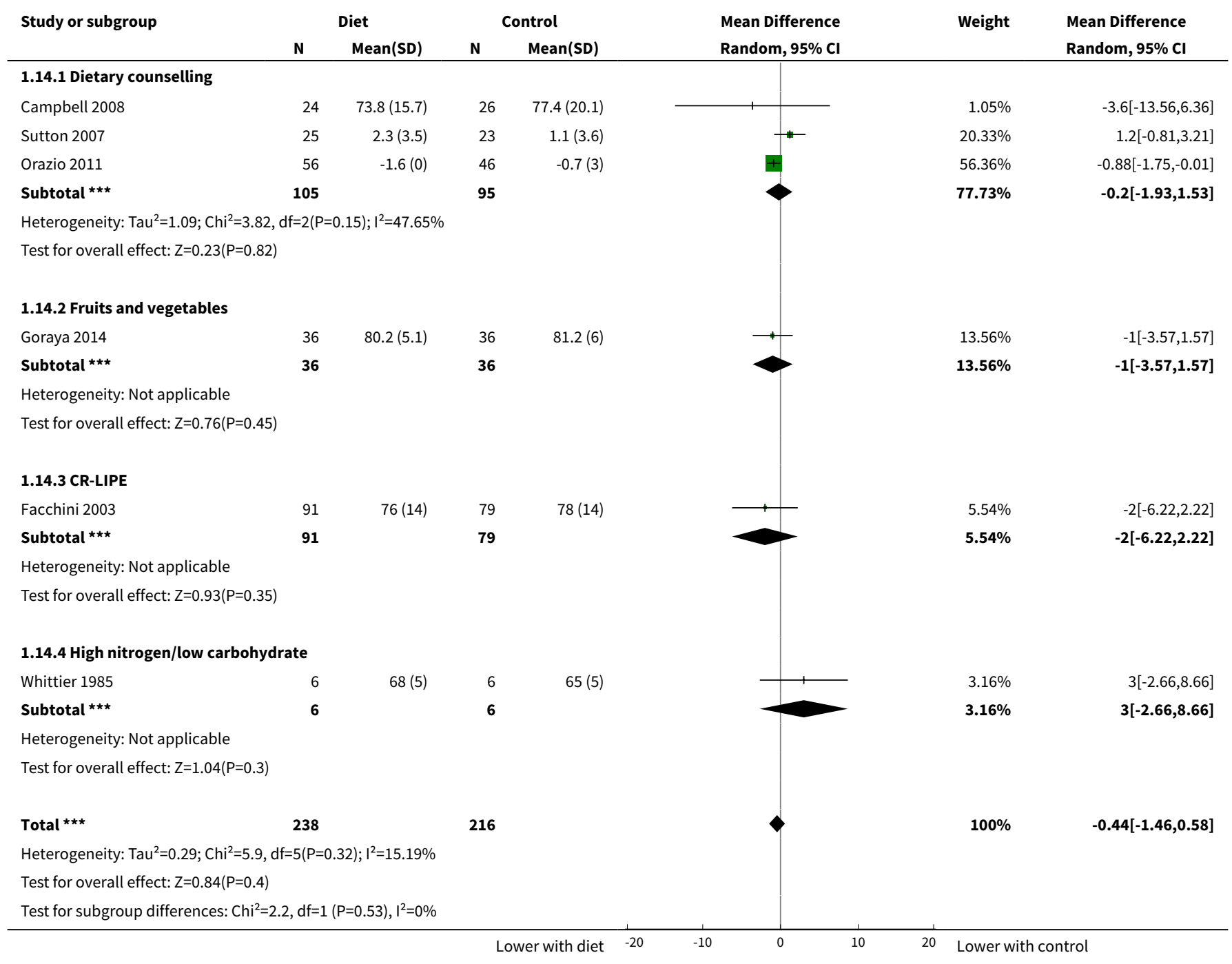

Analysis 1.15. Comparison 1 Dietary intervention versus control, Outcome 15 BMI.

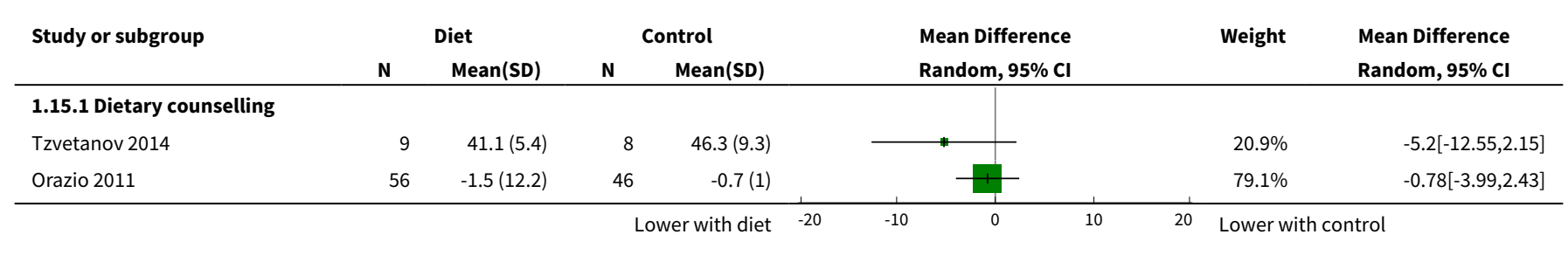




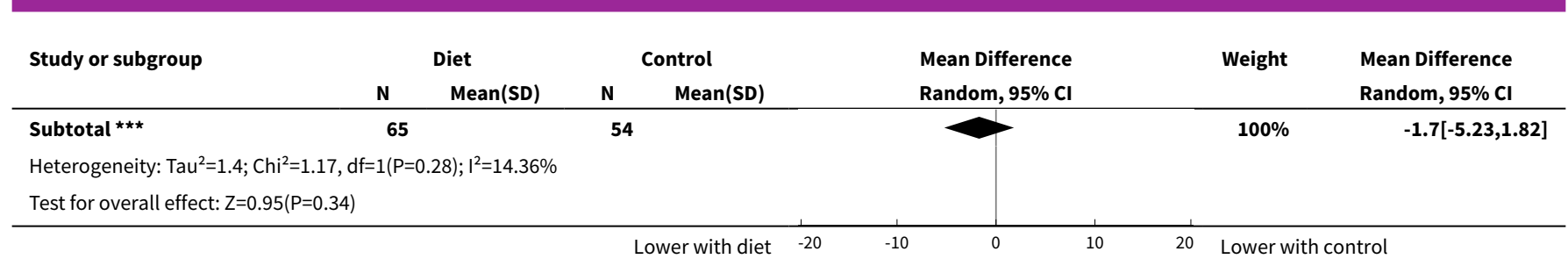

Analysis 1.16. Comparison 1 Dietary intervention versus control, Outcome 16 Waist-hip ratio.

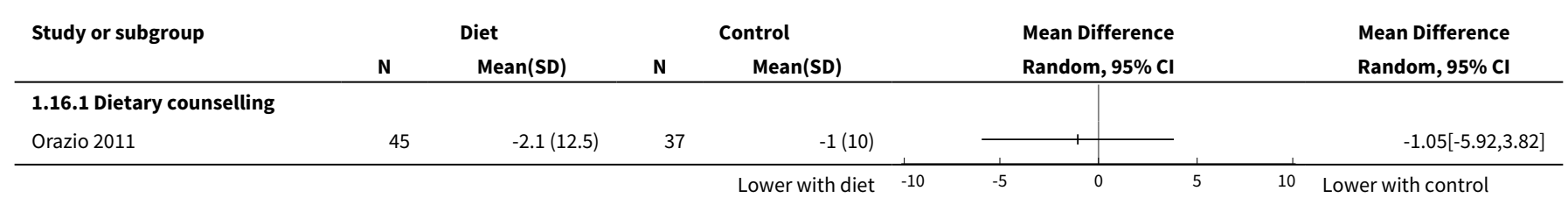

Analysis 1.17. Comparison 1 Dietary intervention versus control, Outcome 17 Waist circumference, $\mathrm{cm}$.

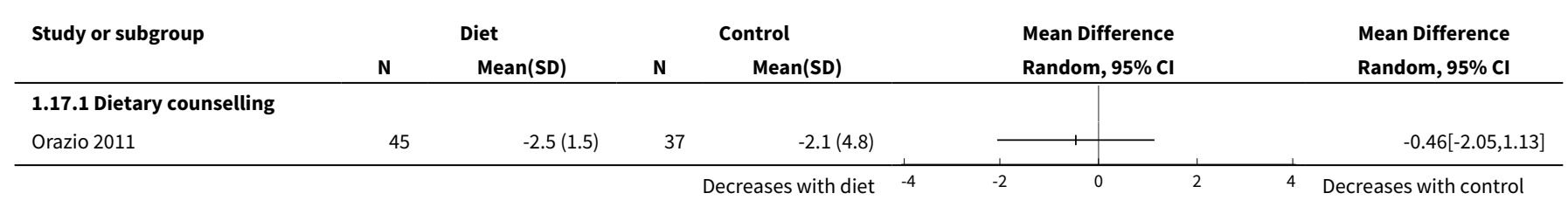

Analysis 1.18. Comparison 1 Dietary intervention versus control, Outcome 18 Arm circumference.

\begin{tabular}{|c|c|c|c|c|c|c|c|}
\hline \multirow[t]{2}{*}{ Study or subgroup } & \multicolumn{2}{|c|}{ Diet } & \multicolumn{2}{|c|}{ Control } & \multirow{2}{*}{$\begin{array}{l}\text { Mean Difference } \\
\text { Random, } 95 \% \mathrm{Cl}\end{array}$} & \multirow[t]{2}{*}{ Weight } & \multirow{2}{*}{$\begin{array}{l}\text { Mean Difference } \\
\text { Random, } 95 \% \mathrm{Cl}\end{array}$} \\
\hline & $\mathbf{N}$ & $\operatorname{Mean}(S D)$ & $\mathbf{N}$ & $\operatorname{Mean}(S D)$ & & & \\
\hline \multicolumn{8}{|c|}{ 1.18.1 Dietary counselling } \\
\hline Sutton 2007 & 25 & $0.5(2)$ & 22 & $0.4(2.1)$ & & $40.95 \%$ & $0.03[-1.15,1.21]$ \\
\hline Zhou 2011b & 52 & $17.9(2.9)$ & 50 & $17.3(2.1)$ & +1 & $59.05 \%$ & $0.6[-0.38,1.58]$ \\
\hline Subtotal $\star \star \star$ & 77 & & 72 & & & $100 \%$ & $0.37[-0.39,1.12]$ \\
\hline \multicolumn{8}{|c|}{ Heterogeneity: $\operatorname{Tau}^{2}=0 ; \mathrm{Chi}^{2}=0.53, \mathrm{df}=1(\mathrm{P}=0.47) ; \mathrm{I}^{2}=0 \%$} \\
\hline \multicolumn{8}{|c|}{ Test for overall effect: $Z=0.95(P=0.34)$} \\
\hline
\end{tabular}

Analysis 1.19. Comparison 1 Dietary intervention versus control, Outcome 19 Serum albumin.

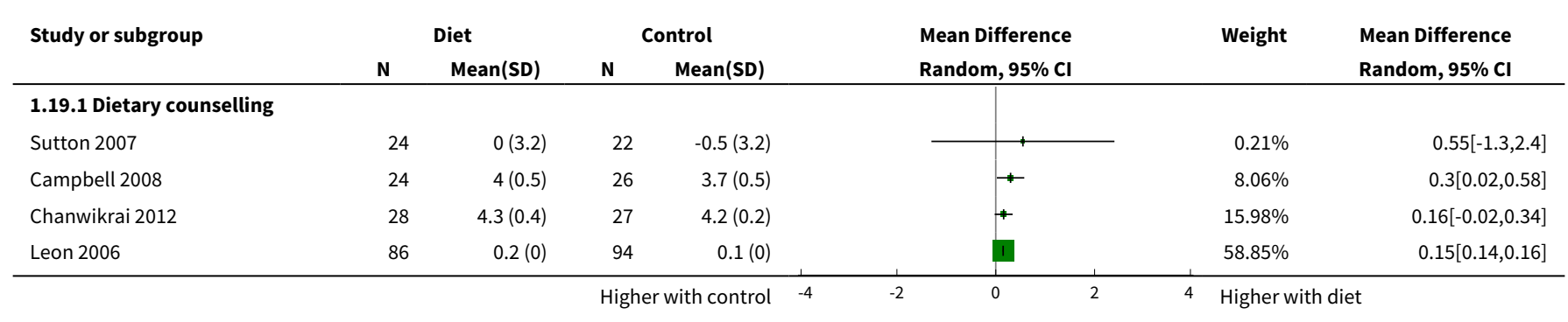




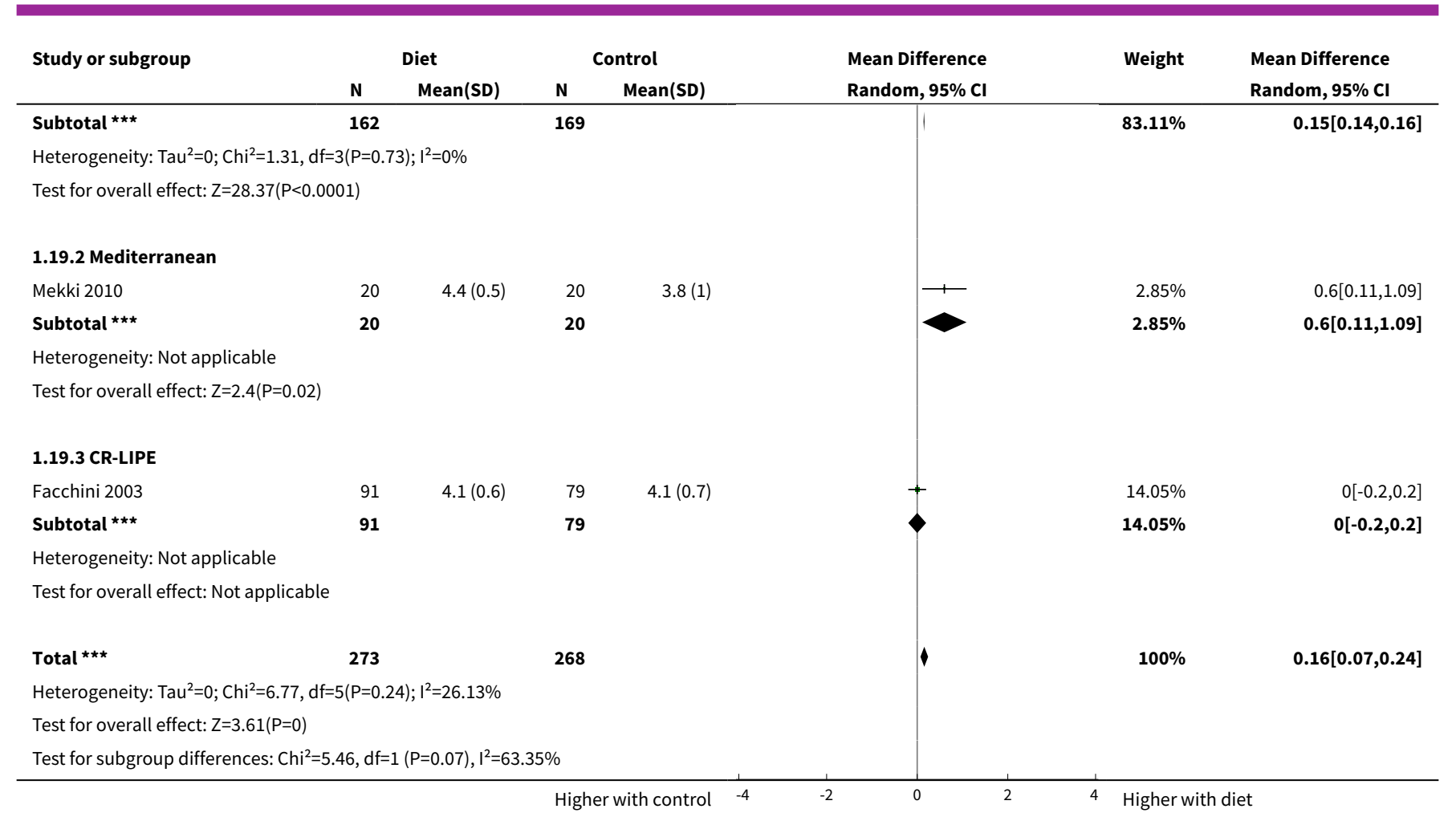

Analysis 1.20. Comparison 1 Dietary intervention versus control, Outcome 20 Serum LDL cholesterol.

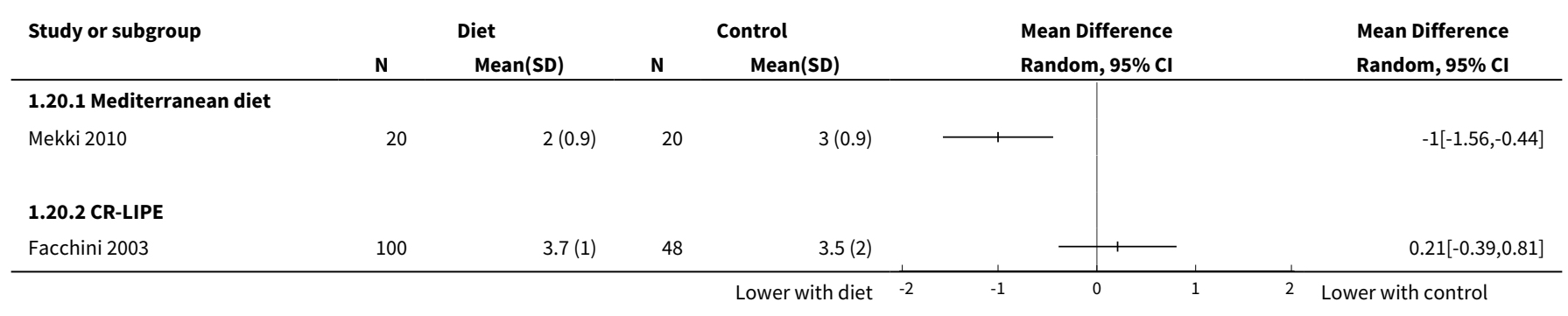

\section{Comparison 2. Mediterranean diet versus low fat}

\begin{tabular}{lllll}
\hline Outcome or subgroup title & No. of studies & $\begin{array}{l}\text { No. of partici- } \\
\text { pants }\end{array}$ & Statistical method & Effect size \\
\hline 1 Serum LDL cholesterol & 1 & & $\begin{array}{l}\text { Mean Difference (IV, Random, 95\% } \\
\text { CI) }\end{array}$ & Totals not selected \\
\hline
\end{tabular}


Analysis 2.1. Comparison 2 Mediterranean diet versus low fat, Outcome 1 Serum LDL cholesterol.

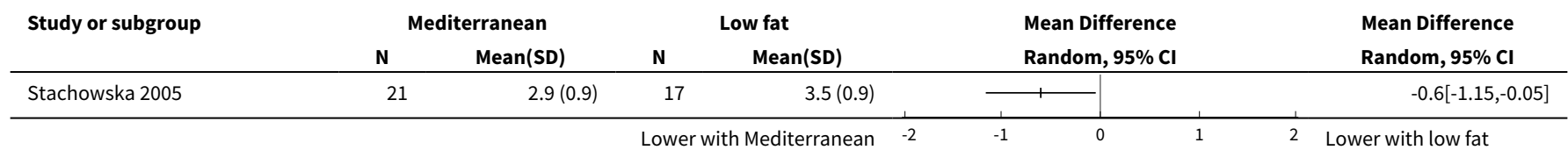

Comparison 3. Fruits and vegetables versus bicarbonate

\begin{tabular}{llllll}
\hline $\begin{array}{l}\text { Outcome or subgroup } \\
\text { title }\end{array}$ & No. of studies & $\begin{array}{l}\text { No. of partici- } \\
\text { pants }\end{array}$ & Statistical method & Effect size \\
\hline $1 \mathrm{eGFR}\left[\mathrm{mL} / \mathrm{min} / 1.73 \mathrm{~m}^{2}\right]$ & 2 & 143 & Mean Difference (IV, Random, 95\% Cl) & $0.84[-0.84,2.53]$ \\
\hline 2 Serum creatinine & 1 & & Mean Difference (IV, Random, 95\% Cl) & Totals not selected \\
\hline 3 Systolic blood pressure & 2 & 143 & Mean Difference (IV, Random, 95\% Cl) & $-5.81[-8.84,-2.77]$ \\
\hline 4 Body weight & 2 & 143 & Mean Difference (IV, Random, 95\% Cl) & $-5.09[-7.73,-2.44]$ \\
\hline
\end{tabular}

Analysis 3.1. Comparison 3 Fruits and vegetables versus bicarbonate, Outcome $1 \mathrm{eGFR}\left[\mathrm{mL} / \mathrm{min} / 1.73 \mathrm{~m}^{2}\right]$.

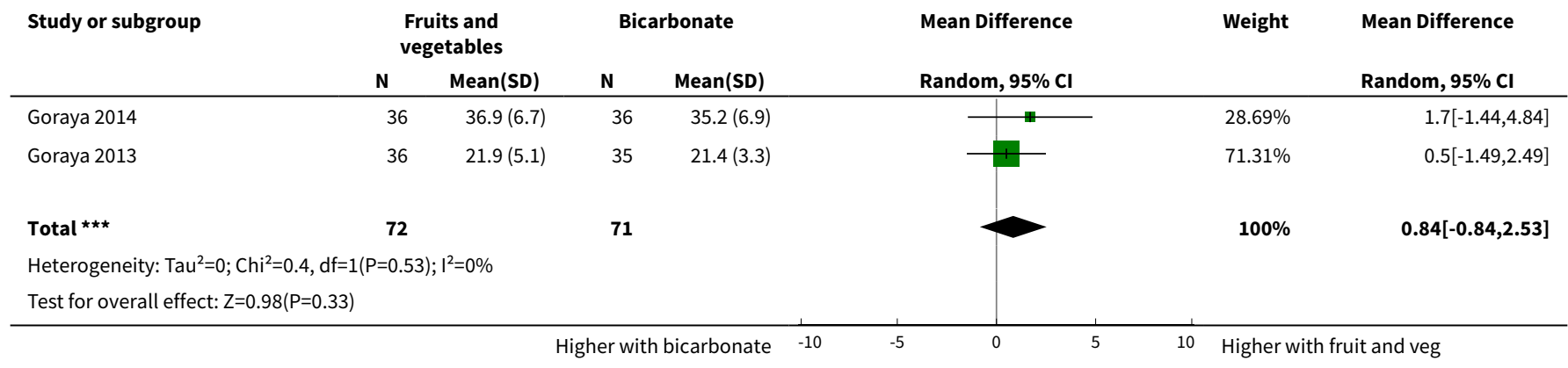

Analysis 3.2. Comparison 3 Fruits and vegetables versus bicarbonate, Outcome 2 Serum creatinine.

\begin{tabular}{|c|c|c|c|c|c|c|c|c|}
\hline \multirow{3}{*}{$\begin{array}{l}\text { Study or subgroup } \\
\text { Goraya } 2013\end{array}$} & \multicolumn{2}{|c|}{ Fruits and vegetables } & \multicolumn{2}{|c|}{ Bicarbonate } & & \multirow{2}{*}{$\begin{array}{l}\text { Mean Difference } \\
\text { Random, } 95 \% \mathrm{Cl}\end{array}$} & & \multirow{2}{*}{$\begin{array}{l}\text { Mean Difference } \\
\text { Random, } 95 \% \mathrm{CI}\end{array}$} \\
\hline & $\mathbf{N}$ & Mean(SD) & $\mathbf{N}$ & Mean(SD) & & & & \\
\hline & 36 & $362(88)$ & 35 & $371(27)$ & & 1 & & $-9[-39.11,21.11]$ \\
\hline
\end{tabular}


Analysis 3.3. Comparison 3 Fruits and vegetables versus bicarbonate, Outcome 3 Systolic blood pressure.

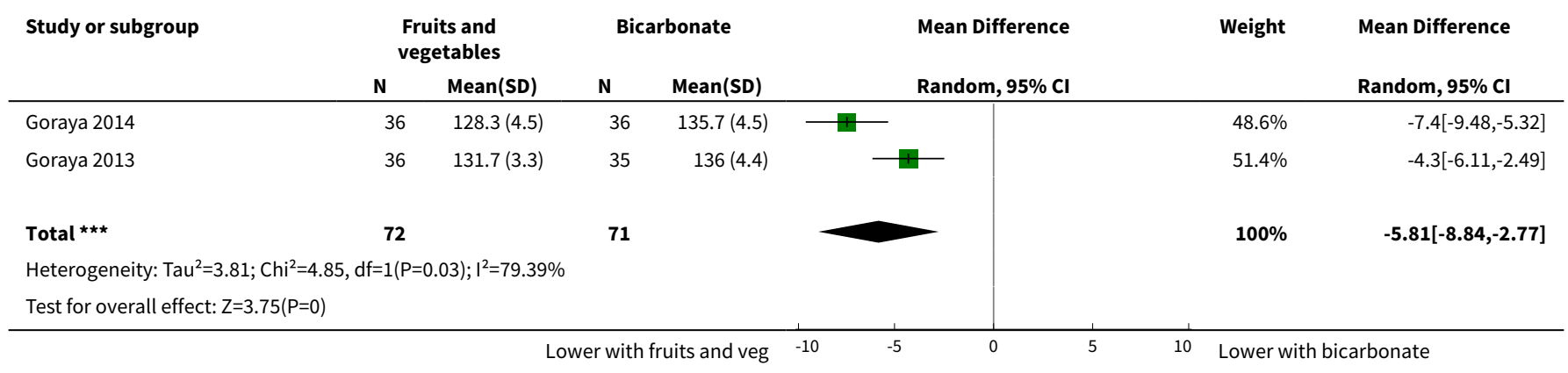

Analysis 3.4. Comparison 3 Fruits and vegetables versus bicarbonate, Outcome 4 Body weight.

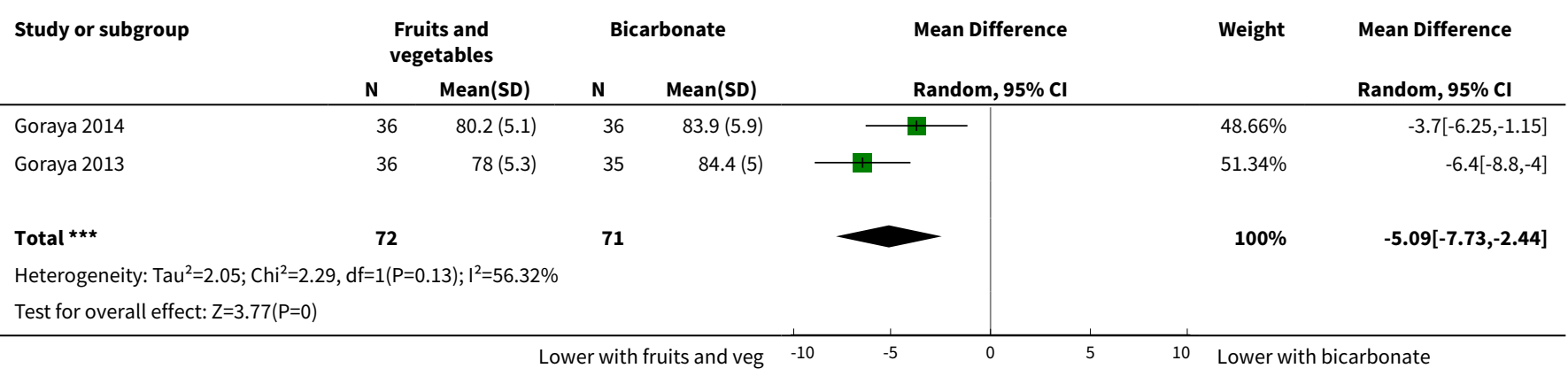




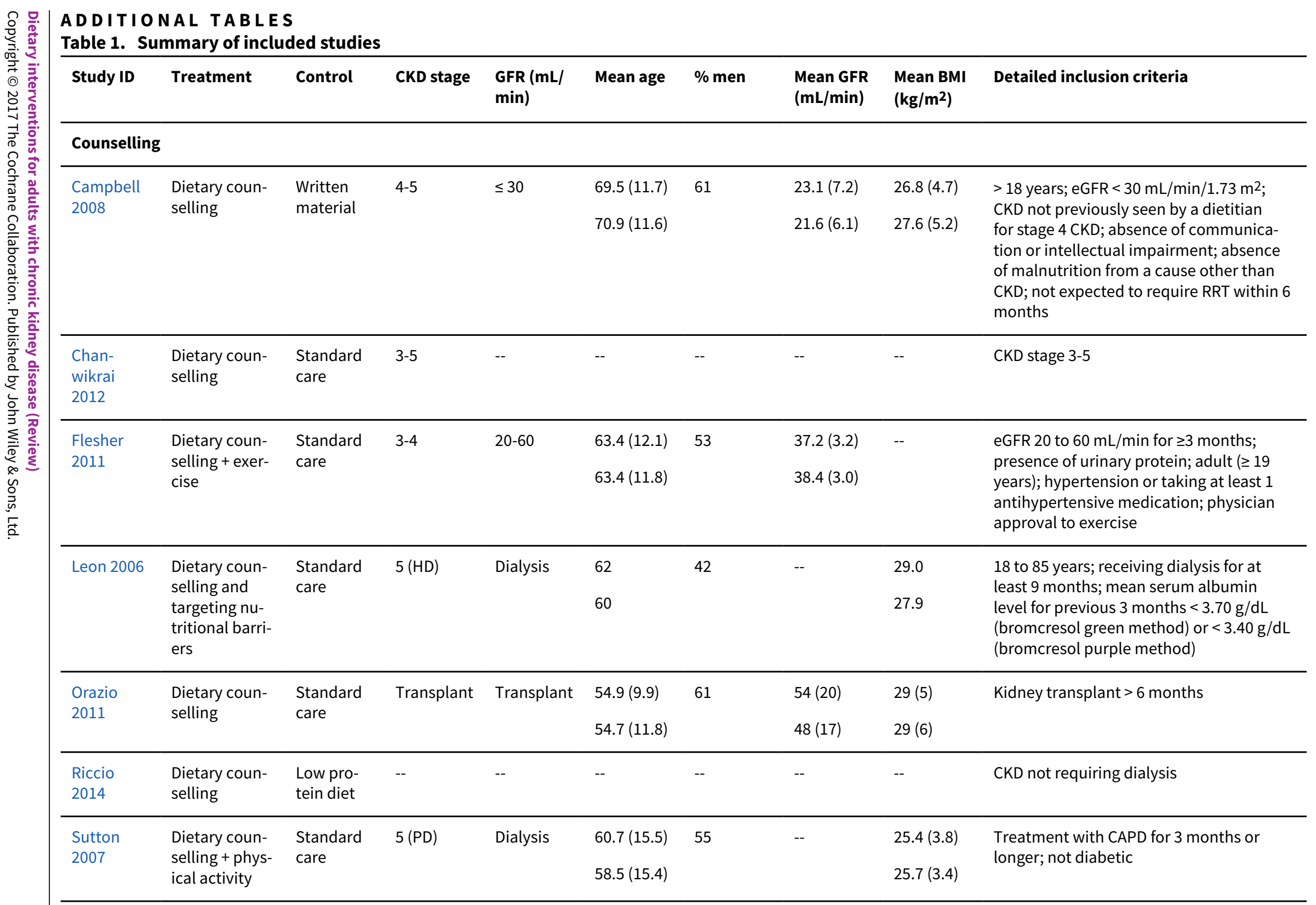




\begin{tabular}{|c|c|c|c|c|c|c|c|c|c|}
\hline Teng 2013 & $\begin{array}{l}\text { Dietary coun- } \\
\text { selling + exer- } \\
\text { cise }\end{array}$ & $\begin{array}{l}\text { Standard } \\
\text { care }\end{array}$ & $1-3$ & -- & $\begin{array}{l}62.1(14.0) \\
65.7(11.2)\end{array}$ & 71 & $\begin{array}{l}53.7(18.3) \\
49.5(13.3)\end{array}$ & $\begin{array}{l}24.4(3.9) \\
25.3(3.1)\end{array}$ & $\begin{array}{l}20 \text { years or older; communicate in Man- } \\
\text { darin or Taiwanese; aware of CKD diagno- } \\
\text { sis; GFR range } 30 \text { to } 106.7 \mathrm{~mL} / \mathrm{min} / 1.73 \mathrm{~m}^{2}\end{array}$ \\
\hline $\begin{array}{l}\text { Tzvetanov } \\
2014\end{array}$ & $\begin{array}{l}\text { Dietary coun- } \\
\text { selling + exer- } \\
\text { cise }\end{array}$ & $\begin{array}{l}\text { Standard } \\
\text { care }\end{array}$ & Transplant & Transplant & $\begin{array}{l}46(6.9) \\
45(19)\end{array}$ & 47 & -- & -- & Kidney transplant; obese \\
\hline $\begin{array}{l}\text { Zhou } \\
\text { 2011b }\end{array}$ & $\begin{array}{l}\text { Dietary coun- } \\
\text { selling }\end{array}$ & $\begin{array}{l}\text { Standard } \\
\text { care }\end{array}$ & $5(\mathrm{PD})$ & Dialysis & $\begin{array}{l}57.8(12.8) \\
59.9(13.6)\end{array}$ & 71 & -- & $\begin{array}{l}23.3(4.5) \\
22.8(6.2)\end{array}$ & $\begin{array}{l}18 \text { to } 70 \text { years; receiving long-term dialysis } \\
>3 \text { months }\end{array}$ \\
\hline \multicolumn{10}{|c|}{ Mediterranean diet } \\
\hline $\begin{array}{l}\text { DIRECT } \\
\text { Study } \\
2013\end{array}$ & $\begin{array}{l}\text { Mediter- } \\
\text { ranean diet } \\
\text { (restricted } \\
\text { calorie) }\end{array}$ & $\begin{array}{l}\text { Low-fat } \\
\text { (restricted } \\
\text { calorie) di- } \\
\text { et } \\
\text { Low-car- } \\
\text { bohydrate } \\
\text { (unre- } \\
\text { stricted } \\
\text { calorie) di- } \\
\text { et }\end{array}$ & 3 & $30-60$ & $52.5(6.2)$ & 99 & $52.6(5.9)$ & $30.9(3.4)$ & $\begin{array}{l}40 \text { to } 65 \text { years with } \mathrm{BMI} \geq 27 \mathrm{~kg} / \mathrm{m}^{2} \text {; indi- } \\
\text { viduals with type } 2 \text { diabetes or coronary } \\
\text { heart disease were eligible regardless of } \\
\text { age. Post-hoc analysis among participants } \\
\text { with eGFR } 30 \text { to } 60 \mathrm{~mL} / \mathrm{min} / 1.73 \mathrm{~m}^{2}\end{array}$ \\
\hline $\begin{array}{l}\text { Mekki } \\
2010\end{array}$ & $\begin{array}{l}\text { Mediter- } \\
\text { ranean diet }\end{array}$ & $\begin{array}{l}\text { Standard } \\
\text { care }\end{array}$ & $2-3$ & $60-89$ & $\begin{array}{l}60(10) \\
59(12)\end{array}$ & 53 & $\begin{array}{l}70(10) \\
75(15)\end{array}$ & $\begin{array}{l}26.9(3.9) \\
25.1(4.2)\end{array}$ & $\begin{array}{l}\text { eGFR } 60 \text { to } 89 \mathrm{~mL} / \mathrm{min} / 1.73 \mathrm{~m}^{2} \text {; dyslipi- } \\
\text { daemia }\end{array}$ \\
\hline $\begin{array}{l}\text { Stachows- } \\
\text { ka } 2005\end{array}$ & $\begin{array}{l}\text { Modified } \\
\text { Mediter- } \\
\text { ranean diet }\end{array}$ & $\begin{array}{l}\text { Low fat di- } \\
\text { et }\end{array}$ & Transplant & Transplant & $\begin{array}{l}41(12.5) \\
46 \\
(9.5)\end{array}$ & 68 & -- & $\begin{array}{l}25.0(4.1) \\
26.2(4.2)\end{array}$ & Stable transplant function \\
\hline \multicolumn{10}{|c|}{ Increased fruit and vegetables } \\
\hline $\begin{array}{l}\text { Goraya } \\
2013\end{array}$ & $\begin{array}{l}\text { Increased } \\
\text { fruit and veg- } \\
\text { etable intake }\end{array}$ & $\begin{array}{l}\text { Oral bicar- } \\
\text { bonate }\end{array}$ & 4 & $15-29$ & $\begin{array}{l}53.9(6.9) \\
54.2(5.3)\end{array}$ & 54 & $\begin{array}{l}22.8(4.9) \\
23.0(3.5)\end{array}$ & -- & $\begin{array}{l}\text { Non-malignant hypertension; eGFR } 15 \text { to } \\
29 \mathrm{~mL} / \mathrm{min} / 1.73 \mathrm{~m}^{2} \text {; plasma } \mathrm{TCO}_{2}<22 \mathrm{mM} \text {; } \\
\text { no diabetes or cardiovascular disease; } \\
\text { two or more primary care physician visits } \\
\text { in previous year; age } \geq 18 \text { years }\end{array}$ \\
\hline
\end{tabular}


Table 1. Summary of included studies (Continued)

\begin{tabular}{|c|c|c|c|c|c|c|c|c|c|}
\hline $\begin{array}{l}\text { Goraya } \\
2014\end{array}$ & $\begin{array}{l}\text { Increased } \\
\text { fruit and veg- } \\
\text { etable intake }\end{array}$ & $\begin{array}{l}\text { Oral bicar- } \\
\text { bonate } \\
\text { Standard } \\
\text { care }\end{array}$ & 3 & $30-59$ & $\begin{array}{l}53.5(5.2) \\
53.9(4.8)\end{array}$ & 44 & $\begin{array}{l}42.3(7.1) \\
42.6(7.6)\end{array}$ & -- & $\begin{array}{l}\text { Non-malignant hypertension, eGFR } 30 \\
\text { to } 59 \mathrm{~mL} / \mathrm{min} / 1.73 \mathrm{~m}^{2} ; \text { plasma } \mathrm{TCO}_{2}<25 \\
\mathrm{mM} ; \mathrm{macroalbuminuria} \text {; able to tolerate } \\
\text { angiotensin-converting inhibition; non- } \\
\text { smoking for } \geq 1 \text { year; no diabetes or car- } \\
\text { diovascular disease; } 2 \text { or more primary } \\
\text { care physician visits in previous year; } \geq 18 \\
\text { years }\end{array}$ \\
\hline \multicolumn{10}{|c|}{ Carbohydrate-restricted, low-iron, polyphenol enriched (CR-LIPE) diet } \\
\hline $\begin{array}{l}\text { Facchini } \\
2003\end{array}$ & CR-LIPE diet & $\begin{array}{l}\text { Protein re- } \\
\text { striction }\end{array}$ & $2-5$ & $15-75$ & $\begin{array}{l}59(10) \\
60(12)\end{array}$ & 51 & $\begin{array}{l}64(28) \\
62(32)\end{array}$ & $\begin{array}{l}28(5) \\
28(5)\end{array}$ & $\begin{array}{l}\text { Type } 2 \text { diabetes; referred to nephrology } \\
\text { clinic for kidney failure }(15 \pm 75 \mathrm{~mL} / \mathrm{min}) \text {; } \\
\text { otherwise unexplained proteinuria }(350 \pm \\
12,000 \mathrm{mg} / \mathrm{d}) \text {; kidney disease attributed to } \\
\text { diabetes }\end{array}$ \\
\hline \multicolumn{10}{|c|}{ High-nitrogen, low-carbohydrate diet } \\
\hline $\begin{array}{l}\text { Whittier } \\
1985\end{array}$ & $\begin{array}{l}\text { High-nitro- } \\
\text { gen, low car- } \\
\text { bohydrate di- } \\
\text { et }\end{array}$ & $\begin{array}{l}\text { Standard } \\
\text { care }\end{array}$ & Transplant & Transplant & $\begin{array}{l}33 \\
32\end{array}$ & 75 & -- & -- & Kidney transplant; no diabetes \\
\hline
\end{tabular}

BMI - body mass index; CAPD - continuous ambulatory peritoneal dialysis; CKD - chronic kidney disease; eGFR - estimated glomerular filtration rate; HD - haemodialysis; PD peritoneal dialysis; RRT - renal replacement therapy; $\mathrm{TCO}_{2}$ - total carbon dioxide

Table 2. TIDieR framework of intervention descriptions for included studies

\begin{tabular}{|c|c|c|c|c|c|c|c|c|c|c|}
\hline \multirow[t]{2}{*}{ Study ID } & \multicolumn{2}{|l|}{ Materials } & \multicolumn{6}{|c|}{ Dietary intervention } & \multicolumn{2}{|l|}{ Adherence } \\
\hline & Why & What & Who & How & Where & $\begin{array}{l}\text { When and } \\
\text { how much }\end{array}$ & Tailoring & $\begin{array}{l}\text { Modifica- } \\
\text { tion }\end{array}$ & Planned & Actual \\
\hline \multicolumn{11}{|c|}{ Counselling } \\
\hline $\begin{array}{l}\text { Campbell } \\
2008\end{array}$ & $\begin{array}{l}\text { To de- } \\
\text { termine } \\
\text { whether } \\
\text { individ- } \\
\text { ual nutri- } \\
\text { tion coun- }\end{array}$ & $\begin{array}{l}\text { Individualised dietary prescrip- } \\
\text { tion (including energy ( } 125 \text { to } \\
146 \mathrm{~kJ} / \mathrm{kg} / \mathrm{d} \text { ) and protein }(0.75 \\
\text { to } 1.0 \mathrm{~g} / \mathrm{kg} / \mathrm{d}) \text { ) incorporating } \\
\mathrm{KDOQI} \text { recommendations to } \\
\text { provide intensive nutritional }\end{array}$ & Dietitian & $\begin{array}{l}\text { Face-to- } \\
\text { face, tele- } \\
\text { phone, } \\
\text { individu- } \\
\text { alised }\end{array}$ & -- & $\begin{array}{l}\text { Baseline } \\
\text { for } 60 \text { min; } \\
\text { then bi- } \\
\text { weekly for } \\
1 \text { st month } \\
\text { (15 to } 30\end{array}$ & $\begin{array}{l}\text { Depend- } \\
\text { ing on } \\
\text { dietary } \\
\text { require- } \\
\text { ments, } \\
\text { diet was }\end{array}$ & $\begin{array}{l}\text { Self-man- } \\
\text { agement } \\
\text { principles: } \\
\text { goal-set- } \\
\text { ting, menu } \\
\text { planning, }\end{array}$ & $\begin{array}{l}\text { Dietary in- } \\
\text { take as- } \\
\text { sessed } \\
\text { using 3- } \\
\text { day food } \\
\text { record, }\end{array}$ & $\begin{array}{l}\text { No patient } \\
\text { voluntarily } \\
\text { withdrew } \\
\text { from the } \\
\text { study }\end{array}$ \\
\hline
\end{tabular}


Table 2. TIDieR framework of intervention descriptions for included studies (Continued) selling im- counselling with regular moni-

proves

toring

body com-

position,

energy in-

take, and

nutritional

status

\begin{tabular}{|c|c|c|c|}
\hline $\begin{array}{l}\min ) \text {; then } \\
\text { weekly } \\
\text { till end of } \\
\text { study peri- } \\
\text { od }\end{array}$ & $\begin{array}{l}\text { tailored } \\
\text { following } \\
\text { clinical da- } \\
\text { ta and ini- } \\
\text { tial inter- } \\
\text { view. De- } \\
\text { livery was } \\
\text { guided by } \\
\text { the med- } \\
\text { ical nutri- } \\
\text { tion thera- } \\
\text { py frame- } \\
\text { work from } \\
\text { the Ameri- } \\
\text { can Dietet- } \\
\text { ic Associa- } \\
\text { tion }\end{array}$ & $\begin{array}{l}\text { label read- } \\
\text { ing, and } \\
\text { identifi- } \\
\text { cation of } \\
\text { foods con- } \\
\text { taining } \\
\text { protein, } \\
\text { sodium, } \\
\text { and so on, } \\
\text { depend- } \\
\text { ing on } \\
\text { require- } \\
\text { ments }\end{array}$ & $\begin{array}{l}\text { verified } \\
\text { by the di- } \\
\text { etitian. } \\
\text { Strategies } \\
\text { to improve } \\
\text { adherence } \\
\text { or fidelity } \\
\text { not report } \\
\text { ed }\end{array}$ \\
\hline
\end{tabular}

tion

\begin{tabular}{|c|c|c|c|c|c|c|c|c|c|c|}
\hline $\begin{array}{l}\text { Chan- } \\
\text { wikrai } \\
2012\end{array}$ & $\begin{array}{l}\text { Changes } \\
\text { of diet and } \\
\text { lifestyle } \\
\text { can slow } \\
\text { progres- } \\
\text { sion of } \\
\text { CKD }\end{array}$ & $\begin{array}{l}\text { Dietary modification with or } \\
\text { without exercise by an empow- } \\
\text { erment approach (including } \\
\text { low protein } 0.6 \text { to } 0.8 \mathrm{~g} / \mathrm{kg} / \mathrm{d} \text { ) } \\
\text { and low salt }(5 \mathrm{~g} / \mathrm{d} \text { ). }\end{array}$ & -- & -- & -- & -- & -- & -- & - & $\begin{array}{l}81(96 \%) \\
\text { completed } \\
\text { the study } \\
\text { program }\end{array}$ \\
\hline $\begin{array}{l}\text { Flesher } \\
2011\end{array}$ & $\begin{array}{l}\text { To de- } \\
\text { termine } \\
\text { whether } \\
\text { additional } \\
\text { of cooking } \\
\text { and exer- } \\
\text { cise class- } \\
\text { es would } \\
\text { slow pro- } \\
\text { gression of } \\
\text { CKD }\end{array}$ & $\begin{array}{l}\text { Individual nutrition counselling } \\
\text { on moderate protein and low } \\
\text { sodium, with individualised } \\
\text { modification of potassium and/ } \\
\text { or phosphate plus a group nu- } \\
\text { trition class, cooking classes } \\
\text { with a dietitian and cook edu- } \\
\text { cation, CKD cookbook, shop- } \\
\text { ping tour, and 12-week exercise } \\
\text { program led by a Certified Exer- } \\
\text { cise Physiologist and nurse. Ex- } \\
\text { ercise program started after } 6 \\
\text { months }\end{array}$ & $\begin{array}{l}\text { Cooking } \\
\text { class - di- } \\
\text { etitian and } \\
\text { cook edu- } \\
\text { cator; Ex- } \\
\text { ercise - } \\
\text { exercise } \\
\text { physiolo- } \\
\text { gist and } \\
\text { nurse }\end{array}$ & $\begin{array}{l}\text { Face-to- } \\
\text { face; indi- } \\
\text { vidual and } \\
\text { group ses- } \\
\text { sions }\end{array}$ & $\begin{array}{l}\text { Exercise } \\
\text { class took } \\
\text { place } \\
\text { in well- } \\
\text { equipped } \\
\text { gym at } \\
\text { Garatt } \\
\text { Wellness } \\
\text { Centre: } \\
\text { details re- } \\
\text { garding } \\
\text { cooking } \\
\text { class not } \\
\text { provided }\end{array}$ & $\begin{array}{l}\text { Cook- } \\
\text { ing class- } \\
\text { es over } \\
4 \text { weeks } \\
\text { for } 2 \text { hour } \\
\text { session, } \\
\text { shopping } \\
\text { tour; Exer- } \\
\text { cise class } \\
\text { at Garratt } \\
\text { Wellness } \\
\text { centre, } 3 x \\
1 \text { hour ses- } \\
\text { sion/week } \\
\text { with } \\
\text { strength } \\
\text { training, } \\
\text { flexibili- } \\
\text { ty compo- }\end{array}$ & $\begin{array}{l}\text { Skills for } \\
\text { tailoring } \\
\text { and mod- } \\
\text { ifying di- } \\
\text { et and } \\
\text { lifestyle } \\
\text { were pro- } \\
\text { vided. Di- } \\
\text { et histo- } \\
\text { ry was dis- } \\
\text { cussed } \\
\text { in detail } \\
\text { at the in- } \\
\text { dividual } \\
\text { appoint- } \\
\text { ments }\end{array}$ & $\begin{array}{l}\text { Self-man- } \\
\text { agement } \\
\text { focus in } \\
\text { using goal- } \\
\text { setting } \\
\text { and build- } \\
\text { ing confi- } \\
\text { dence in } \\
\text { the man- } \\
\text { agement } \\
\text { of disease }\end{array}$ & $\begin{array}{l}\text { Adherence } \\
\text { to exer- } \\
\text { cise was } \\
\text { assessed } \\
\text { by physi- } \\
\text { cal activity } \\
\text { readiness } \\
\text { question- } \\
\text { naire and } \\
6 \text { minute } \\
\text { submaxi- } \\
\text { mal walk } \\
\text { test; bio- } \\
\text { chemical } \\
\text { and clini- } \\
\text { cal para- } \\
\text { meters re- } \\
\text { lated to } \\
\text { cardio- }\end{array}$ & $\begin{array}{l}\text { Overall, } \\
\text { the ex- } \\
\text { perimen- } \\
\text { tal group } \\
\text { showed } \\
\text { 'improve- } \\
\text { ment" } \\
\text { in their } \\
\text { exercise } \\
\text { frequen- } \\
\text { cy, con- } \\
\text { cern over } \\
\text { health } \\
\text { condition, } \\
\text { and fre- } \\
\text { quency } \\
\text { of visits } \\
\text { to health } \\
\text { providers }\end{array}$ \\
\hline
\end{tabular}




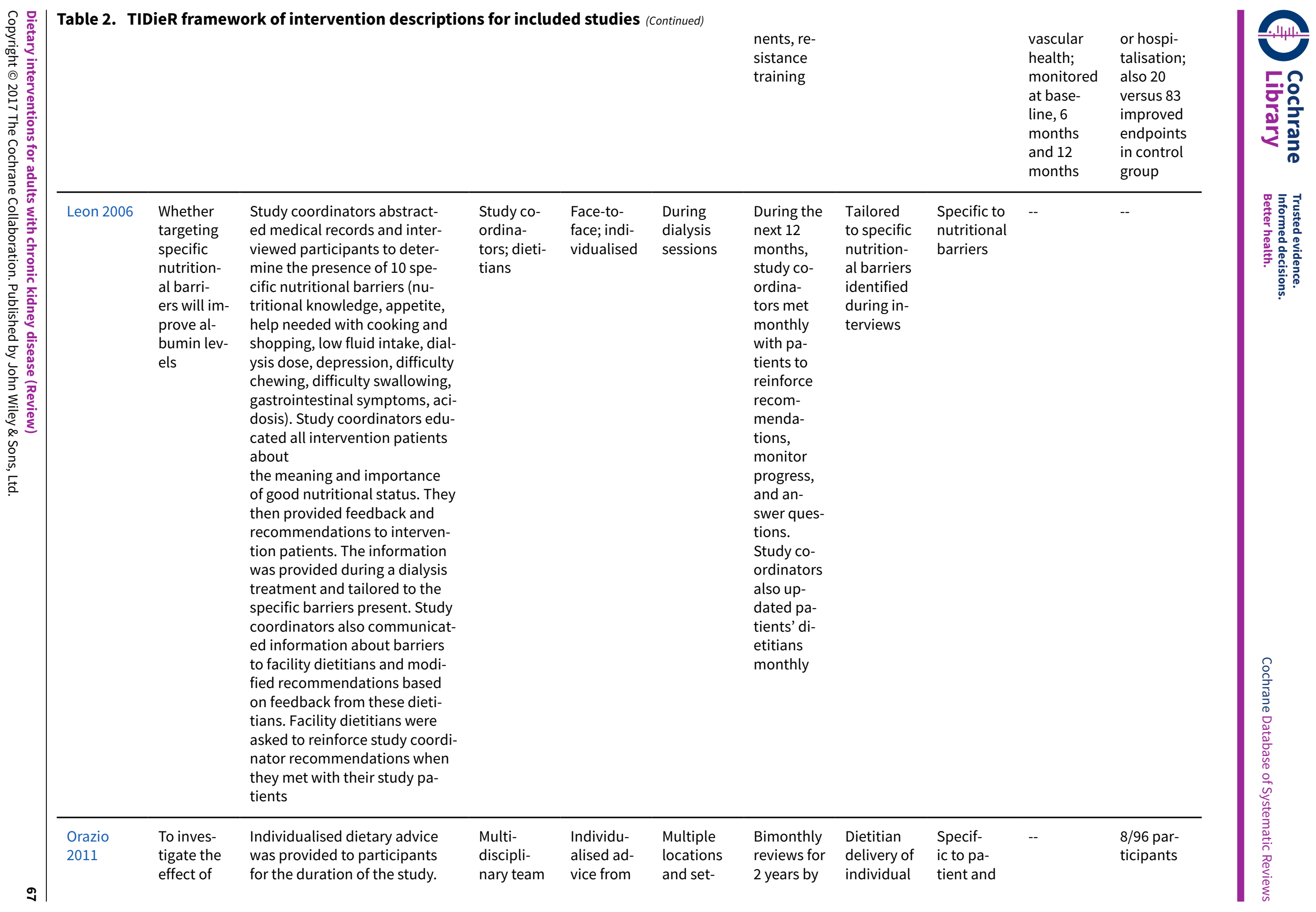


Table 2. TIDieR framework of intervention descriptions for included studies (Continued)

\section{dietitian}

involve-

Achievement and/or main-

ment in a

tenance of a healthy weight

(nephrolo-

nephrolo-

tings in

(BMI), 20 to $25 \mathrm{~kg} / \mathrm{m}^{2}$ ) was the

gist, dietit-

gist, dietit-

cluding

ciplinary

primary goal of nutrition thera-

ian, nurse,

, nurse

during

lifestyle in-

py using a Mediterranean-style

endocri-

and en-

(< $30 \%$ total energy from

fat), low GI diet. A moderate

risk fac-

energy deficit of $500 \mathrm{kcal} / \mathrm{d}$
$(2,000 \mathrm{~kJ} / \mathrm{d})$ to promote 0.5

kg of weight loss/week was

ification used. Study materials used to

for cardio- teach participants included a

vascular study manual with dietary and

disease lifestyle information, food mod-

with stan- els, and pictures.

dard post-

transplant The long-term goal of physical

care in activity advice was to achieve

kidney $\quad 150$ min of accumulated phys-

transplant ical activity/week, in accor-

recipients dance with current National

with ab- Physical Activity Recommen-

normal dations. To help achieve this,

glucose goals

tolerance were individualised for each

patient according to

mobility, fitness, personal pref-

erence, and self-efficacy

for activities. Moderate physi-

cal activity, such as walking,

was encouraged, both as struc-

tured activity

and activity of daily living.

The Transtheoretical Model

of Health Behavior Change or

Stage of Change Model under-

pinned the lifestyle interven-

tion to provide a framework

for goal-setting throughout the

study

$\begin{array}{lll}\text { Riccio } & \begin{array}{l}\text { To deter- } \\ \text { mine if a } \\ \text { simplified }\end{array} & \begin{array}{l}\text { List of recommendations to } \\ \text { modify dietary habits (do not } \\ \text { add salt at table or for cookin }\end{array}\end{array}$

Face-to-

face; indi-

vidualised
The goal

of the

study was

to tailor
Adherence

to diet was

assessed

interven-

tion group 
Table 2. TIDieR framework of intervention descriptions for included studies (Continued)

\section{approach dles or bread; meat, fish and}

self-man- egg intake; 4-5 servings of fruit

aged by or vegetables; replacement of

patients noodles with legumes

had ben-

eficial im-

pact on

nutrition-

al and

metabol-

ic control

of CKD, to

be accept-

able and

safe

and modi-

fy diet for

partici-

pants in

interven-

tion group

(not other-

wise spec-

ified ar inter-

vals $(1,3$

method scription

for assess- where-

ing adher- as $12 / 27$

ence was in con-

not report- trol group

ed

were ad-

herent

with pro-

tein pre-

scription

Sutton To de- The intervention group was of-

termine

fered follow-up dietary advice

whether

that would encourage them to

offering match energy intake with their

dietary ad- estimated energy expenditure

vice was allowing for dialysate calories

effective and with a protein intake of not

Dietitian $\begin{aligned} & \text { Face-to- } \\ & \text { face }\end{aligned}$

face con-

tact at

baseline

and 4

months.

Suggest-

ed snack

ideas, al-

porting

$<0.8$ to $1.0 \mathrm{~g} / \mathrm{kg} \mathrm{IBW}$

patients in

adjusting

energy in-

terations

in food

prepara-

tion, or

modifi-

cation of

portion

sizes

\begin{tabular}{|c|c|c|c|c|c|c|c|c|c|c|}
\hline Teng 2013 & $\begin{array}{l}\text { To exam- } \\
\text { ine ef- } \\
\text { fects of a } \\
\text { targeted } \\
\text { Lifestyle } \\
\text { Modifica- } \\
\text { tion Pro- } \\
\text { gram on } \\
\text { lifestyle } \\
\text { behav- } \\
\text { iours, }\end{array}$ & $\begin{array}{l}\text { The Trans Theoretical mod- } \\
\text { el using the stage-of-change } \\
\text { construct was used to assess } \\
\text { the patient's readiness stage } \\
\text { to promote behaviour change. } \\
\text { Targeted interventions were } \\
\text { given according to the stage } \\
\text { of change about diet and exer- } \\
\text { cise. Patients were encouraged } \\
\text { to find individual methods of } \\
\text { overcoming barriers to regu- }\end{array}$ & $\begin{array}{l}\text { Registered } \\
\text { nurse re- } \\
\text { search as- } \\
\text { sistants }\end{array}$ & $\begin{array}{l}\text { Face-to- } \\
\text { face; indi- } \\
\text { vidualised }\end{array}$ & Clinic & $\begin{array}{l}\text { Coun- } \\
\text { selling } \\
\text { provided } \\
\text { with each } \\
\text { clinic visit }\end{array}$ & $\begin{array}{l}\text { The goal } \\
\text { of the } \\
\text { study to } \\
\text { tailor and } \\
\text { modify di- } \\
\text { et for par- } \\
\text { ticipants } \\
\text { in inter- } \\
\text { vention } \\
\text { group }\end{array}$ & -- & $\begin{array}{l}\text { To ensure } \\
\text { the fideli- } \\
\text { ty of the } \\
\text { Lifestyle } \\
\text { Modifica- } \\
\text { tion Pro- } \\
\text { gram, all } \\
\text { provid- } \\
\text { ed coun- } \\
\text { selling and } \\
\text { informa- }\end{array}$ & $\begin{array}{l}\text { There was } \\
\text { a } 64.4 \% \\
\text { retention } \\
\text { rate at } 12 \\
\text { months }\end{array}$ \\
\hline
\end{tabular}

iours,

overcoming barriers to regu-

informa-

49/59 par-

ticipants

completed

the study

informa-




\begin{tabular}{|c|c|c|c|c|c|c|c|c|c|c|c|}
\hline & $\begin{array}{l}\text { knowl- } \\
\text { edge, and } \\
\text { physical } \\
\text { indicators } \\
\text { of CKD }\end{array}$ & $\begin{array}{l}\text { lar exercise. Written materials } \\
\text { were provided to encourage ad- } \\
\text { herence to a CKD diet. An infor- } \\
\text { mation booklet on protecting } \\
\text { kidney function was provided } \\
\text { and reviewed with patient. Dis- } \\
\text { cussion provided information } \\
\text { about kidney function and dis- } \\
\text { ease, and dietary and lifestyle } \\
\text { management }\end{array}$ & & & & & & & $\begin{array}{l}\text { tion were } \\
\text { record- } \\
\text { ed, and } \\
\text { the inter- } \\
\text { ventions } \\
\text { were re- } \\
\text { viewed by } \\
\text { the inves- } \\
\text { tigators at } \\
\text { random }\end{array}$ & & 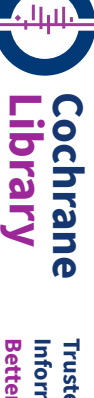 \\
\hline $\begin{array}{l}\text { Tzvetanov } \\
2014\end{array}$ & $\begin{array}{l}\text { Examine } \\
\text { the effec- } \\
\text { tiveness of } \\
\text { a physical } \\
\text { exercise } \\
\text { program } \\
\text { including } \\
\text { behaviour } \\
\text { modifica- } \\
\text { tion inter- } \\
\text { ventions } \\
\text { and nu- } \\
\text { tritional } \\
\text { training } \\
\text { for obese } \\
\text { recipients } \\
\text { of a kidney } \\
\text { transplant }\end{array}$ & $\begin{array}{l}\text { Individual physical training } \\
\text { (one-to-one sessions with a } \\
\text { coach) using low-impact, low- } \\
\text { repetition, resistance-based } \\
\text { weight training with } 2 \text { x 1-hour } \\
\text { sessions each week in } \\
\text { a private environment. The ob- } \\
\text { jective of the exercise protocol } \\
\text { was to maximize adherence, } \\
\text { improve medical health, reduce } \\
\text { pain, improve energy, and en- } \\
\text { hance emotional wellness and } \\
\text { quality of life. Each session had } \\
\text { a clearly defined protocol in- } \\
\text { corporating physical, educa- } \\
\text { tional, and psychological as- } \\
\text { pects }\end{array}$ & Coach & $\begin{array}{l}\text { Individual } \\
\text { training }\end{array}$ & $\begin{array}{l}\text { Private en- } \\
\text { vironment }\end{array}$ & $\begin{array}{l}2 \times 1 \text {-hour } \\
\text { sessions } \\
\text { each week } \\
\text { for } 12 \\
\text { months }\end{array}$ & $\begin{array}{l}\text { Stan- } \\
\text { dardised } \\
\text { process } \\
\text { and cur- } \\
\text { ricu- } \\
\text { lum cus- } \\
\text { tomised to } \\
\text { each indi- } \\
\text { vidual pa- } \\
\text { tients' en- } \\
\text { ergy lev- } \\
\text { el, medical } \\
\text { wellness, } \\
\text { physical } \\
\text { status/lim- } \\
\text { itations, } \\
\text { and emo- } \\
\text { tional life }\end{array}$ & $\begin{array}{l}\text { Response } \\
\text { to par- } \\
\text { ticipants } \\
\text { muscle } \\
\text { strength, } \\
\text { empower- } \\
\text { ment, and } \\
\text { identify- } \\
\text { ing most } \\
\text { impact- } \\
\text { ful behav- } \\
\text { iour/lifestyle } \\
\text { changes } \\
\text { for each } \\
\text { patient }\end{array}$ & - & $\begin{array}{l}\text { Only 4/8 } \\
\text { people } \\
\text { allocat- } \\
\text { ed to the } \\
\text { control } \\
\text { returned } \\
\text { to the } 6 \\
\text { month fol- } \\
\text { low up } \\
\text { appoint- } \\
\text { ment and } \\
2 \text { for the } \\
12 \text { month } \\
\text { appoint- } \\
\text { ment. Ad- } \\
\text { herence } \\
\text { with the } \\
\text { supervised } \\
\text { rehabilita- } \\
\text { tion pro- } \\
\text { gram and } \\
\text { follow up } \\
\text { was } 100 \% \\
\text { in people } \\
\text { allocated } \\
\text { to the in- } \\
\text { tervention }\end{array}$ & 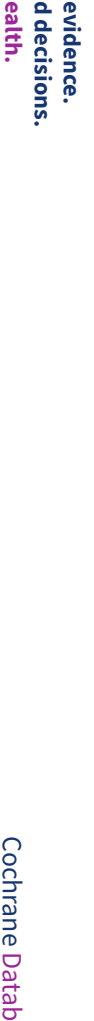 \\
\hline $\begin{array}{l}\text { Zhou } \\
\text { 2011b }\end{array}$ & $\begin{array}{l}\text { To inves- } \\
\text { tigate the } \\
\text { effects of } \\
\text { nutrition } \\
\text { interven- } \\
\text { tion and }\end{array}$ & $\begin{array}{l}\text { An individualised nutrition in- } \\
\text { tervention developed by dietit- } \\
\text { ian with regard to the patient's } \\
\text { nutritional status, clinical con- } \\
\text { dition, and characteristics. The } \\
\text { study group received the fol- }\end{array}$ & $\begin{array}{l}\text { Dietitian } \\
\text { and nurs- } \\
\text { es }\end{array}$ & $\begin{array}{l}\text { Individual } \\
\text { face-to- } \\
\text { face }\end{array}$ & -- & $\begin{array}{l}\text { Psycho- } \\
\text { logical } \\
\text { support } \\
\text { was giv- } \\
\text { en for } 30 \\
\text { min once- }\end{array}$ & $\begin{array}{l}\text { Individu- } \\
\text { alised ac- } \\
\text { cording to } \\
\text { nutritional } \\
\text { and clini- } \\
\text { cal status }\end{array}$ & -- & -- & $\begin{array}{l}\text { Not re- } \\
\text { ported }\end{array}$ & . \\
\hline
\end{tabular}


Table 2. TIDieR framework of intervention descriptions for included studies (Continued)

individ- lowing intervention: energy 125

ualised $\quad \mathrm{kJ} / \mathrm{kg} / \mathrm{d}$, protein 1.2 to $1.3 \mathrm{~g} /$

month-

nursing $\quad \mathrm{kg} / \mathrm{d}$, and $70 \%$ to $75 \%$ propor-

care on tion of protein as of high bio-

nutrition- logical value. Oral enteral nu-

al status trition supplements were used

and qual- for patients who did not receive

months

ity of life enough nutrients from food.

in people The volume of water intake was

with ESKD equivalent to the urine volume

receiving plus $500 \mathrm{~mL} / \mathrm{d}$ and sodium was

peritoneal $3 \mathrm{~g} / \mathrm{d}$. In addition, nurse practi-

dialysis tioners provided psychological

care, an individualised exercise

program, and blood pressure

treatment

Mediterranean diet

\begin{tabular}{|c|c|c|c|c|c|c|c|c|c|c|}
\hline $\begin{array}{l}\text { DIRECT } \\
\text { Study } \\
2013\end{array}$ & $\begin{array}{l}\text { To inves- } \\
\text { tigate the } \\
\text { long-term } \\
\text { effect of } \\
\text { Mediter- } \\
\text { ranean di- } \\
\text { et on kid- } \\
\text { ney func- } \\
\text { tion }\end{array}$ & $\begin{array}{l}\text { Mediterranean diet: moder- } \\
\text { ate-fat, restricted calorie, rich } \\
\text { in vegetables and low in red } \\
\text { meat, with poultry and fish re- } \\
\text { placing beef and lamb. Energy } \\
\text { intake was restricted to } 1500 \\
\mathrm{kcal} / \mathrm{d} \text { for women and } 1800 \\
\mathrm{kcal} / \mathrm{d} \text { for men, with a goal of } \\
\text { no more than } 35 \% \text { of calories } \\
\text { from fat; the main sources of } \\
\text { added fat were } 30 \text { to } 45 \mathrm{~g} \text { of } \\
\text { olive oil and a handful of nuts ( } 5 \\
\text { to } 7 \text { nuts, }<20 \text { g)/d. } \\
\text { Low carbohydrate diet: low- } \\
\text { carbohydrate, non-restrict- } \\
\text { ed-calorie diet aimed to pro- } \\
\text { vide } 20 \mathrm{~g} \text { of carbohydrates/d for } \\
\text { the } 2 \text {-month induction phase } \\
\text { and immediately after religious } \\
\text { holidays, with a gradual in- } \\
\text { crease to a maximum of } 120 \mathrm{~g} / \\
\mathrm{d} \text { to maintain weight loss. } \\
\text { Low fat diet: Low-fat calorie re- } \\
\text { stricted diet based on Ameri- } \\
\text { can Heart Assoriation } \text { guide- }\end{array}$ & Dietitian & $\begin{array}{l}\text { Members } \\
\text { of each } \\
\text { treatment } \\
\text { group } \\
\text { were as- } \\
\text { signed } \\
\text { to sub- } \\
\text { groups of } \\
\text { between } \\
17 \text { and } \\
19 \text { partic- } \\
\text { ipants, } \\
\text { with } 6 \\
\text { groups } \\
\text { for each } \\
\text { dietary } \\
\text { treatment } \\
\text { group. } \\
\text { Each } \\
\text { group was } \\
\text { assigned } \\
\text { to a reg- } \\
\text { istered } \\
\text { dietitian } \\
\text { who led } \\
\text { all } 6 \text { sub- }\end{array}$ & -- & $\begin{array}{l}\text { Dietitians } \\
\text { met with } \\
\text { groups in } \\
\text { weeks 1, } \\
3,5 \text {, and 7, } \\
\text { and there- } \\
\text { after at 6- } \\
\text { week in- } \\
\text { tervals, } \\
\text { for a to- } \\
\text { tal of } 18 \\
\text { sessions } \\
\text { of } 90 \text { min } \\
\text { each. The } \\
\text { Israeli ver- } \\
\text { sion of the } \\
\text { diabetes } \\
\text { preven- } \\
\text { tion pro- } \\
\text { gram was } \\
\text { adapted } \\
\text { including } \\
\text { addition- } \\
\text { al themes } \\
\text { for each } \\
\text { dietary }\end{array}$ & $\begin{array}{l}6 \text { times } \\
\text { during the } \\
2 \text {-year in- } \\
\text { terven- } \\
\text { tion, an- } \\
\text { other di- } \\
\text { etitian } \\
\text { conduct- } \\
\text { ed } 10 \text { to } 15 \\
\text { min moti- } \\
\text { vational } \\
\text { telephone } \\
\text { calls with } \\
\text { patients } \\
\text { who were } \\
\text { having dif- } \\
\text { ficulty ad- } \\
\text { hering to } \\
\text { the diet. }\end{array}$ & -- & $\begin{array}{l}\text { Adherence } \\
\text { with the } \\
\text { diets was } \\
\text { evaluat- } \\
\text { ed by a } \\
\text { validat- } \\
\text { ed food- } \\
\text { frequency } \\
\text { question- } \\
\text { naire that } \\
\text { included } \\
127 \text { food } \\
\text { items and } \\
\text { three por- } \\
\text { tion-size } \\
\text { pictures } \\
\text { for } 17 \\
\text { items. A } \\
\text { subgroup } \\
\text { of par- } \\
\text { ticipants } \\
\text { complet- } \\
\text { ed two re- } \\
\text { peated 24- } \\
\text { hour di- } \\
\text { etary re- }\end{array}$ & $\begin{array}{l}\text { Adherence } \\
\text { with study } \\
\text { interven- } \\
\text { tion was } \\
95.4 \% \text { at } \\
\text { first year } \\
\text { and } 84.6 \% \\
\text { at second } \\
\text { year }\end{array}$ \\
\hline
\end{tabular}


$1800 \mathrm{kcal} / \mathrm{d}$ for men with $30 \%$

dietary

of calories from fat, $10 \%$ of

group.

calories from saturated fat,

and an intake of $300 \mathrm{mg}$ of

Self-ser-

a group of

solute in-

cholesterol/d. Patients were

vice cafe-

received

take. We

terias in

education.

used a

counselled to consume low-fat

work-

grains, vegetables, fruits, and places

legumes and to limit consump- worked

tion of additional fats, sweets, closely

and high-fat snacks.

with di-

etitians

to adjust

specific

post-hoc analysis of the main

food items

study including people with

to spe-

validat-

ed ques-

tionnaire

to assess

physical

activity. At

baseline,

and at 6,

12 , and 24

months of

follow-up,

the ques-

cific diet

tionnaires

groups.

Each food

item was

provided

with a la-

bel show-

ing the

number

of calories

and the

number of

grams of

carbohy-

drates, fat

and satu-

were self-

adminis-

tered elec-

tronical-

ly through

the work-

place in-

tranet.

The 15\%

of patients

who re-

quest aid

in com-

pleting

the ques

tionnaires

were as-

sisted by

the study

nurse

\begin{tabular}{|c|c|c|c|c|c|c|c|c|c|c|}
\hline $\begin{array}{l}\text { Mekki } \\
2010\end{array}$ & $\begin{array}{l}\text { To eval- } \\
\text { uate ef- } \\
\text { fect of nu- } \\
\text { tritional } \\
\text { advice on } \\
\text { dyslipi- } \\
\text { daemia }\end{array}$ & $\begin{array}{l}\text { Nutritional advice based on the } \\
\text { National Kidney Foundation- } \\
\text { Kidney Disease Outcomes Qual- } \\
\text { ity Initiative guideline (energy } \\
\text { intake } 0.12 \mathrm{MJ} / \mathrm{kg} \mathrm{BW} / \mathrm{d} \text {, pro- } \\
\text { tein } 0.75 \mathrm{~g} / \mathrm{kg} \text { BW/d, lipid intake } \\
35 \% \text {, and carbohydrates } 55 \%\end{array}$ & -- & $\begin{array}{l}\text { Face-to- } \\
\text { face }\end{array}$ & $\begin{array}{l}\text { Nephrolo- } \\
\text { gy ward }\end{array}$ & -- & -- & -- & $\begin{array}{l}\text { Recall and } \\
\text { record } \\
\text { every } 4 \\
\text { days, pa- } \\
\text { tients in- } \\
\text { terviewed } \\
\text { by trained }\end{array}$ & $\begin{array}{l}\text { By } 90 \\
\text { days, the } \\
\text { qualita- } \\
\text { tive distri- } \\
\text { bution of } \\
\text { nutrients } \\
\text { had a ten- }\end{array}$ \\
\hline
\end{tabular}


fied and adapted to a Mediter-

adapt-

ranean diet with increased in-

ed and

o the rec-

take of mono-unsaturated fat-

structure

ommend-

ty acids (MUFA), poly-unsatu-

question-

rated fatty acids (PUFA), and

naire re-

fibres. Patients were asked to

garding

consume olive oil and nuts for

seasonings, whole grains (50 g

24 hour

bread at each meal, 250 cere-

dietary

(once a day), vegetables (200

Serving

$\mathrm{g}$ twice a day) and fish (twice a

week). A list of foods rich in salt,

sizes were

estimat-

ed by the

potassium and phosphorus was

provided. In addition, patients

use of the

received advice about cooking

food por-

tion mod-

methods best suited to adhe

el hand-

book. Di-

mensions

of dishes,

utensils

and

foods

were mea-

sured, and

the por-

tion sizes

were esti-

mated ac-

curately.

The con-

sumed

foods

were con-

verted in-

to various

nutrients

using the

software

GENI

\begin{tabular}{|c|c|c|c|c|c|c|c|c|c|c|}
\hline $\begin{array}{l}\text { Stachows- } \\
\text { ka } 2005\end{array}$ & $\begin{array}{l}\text { To veri- } \\
\text { fy the ef- } \\
\text { fect of the }\end{array}$ & $\begin{array}{l}\text { This diet featured carbohy- } \\
\text { drates with a low GI (poor in } \\
\text { glucose, simple carbohydrates, }\end{array}$ & -- & -- & -- & -- & -- & -- & $\begin{array}{l}\text { Dietary } \\
\text { adherence } \\
\text { was as- }\end{array}$ & $\begin{array}{l}\text { The con- } \\
\text { tent of ole- } \\
\text { ic acid in }\end{array}$ \\
\hline
\end{tabular}




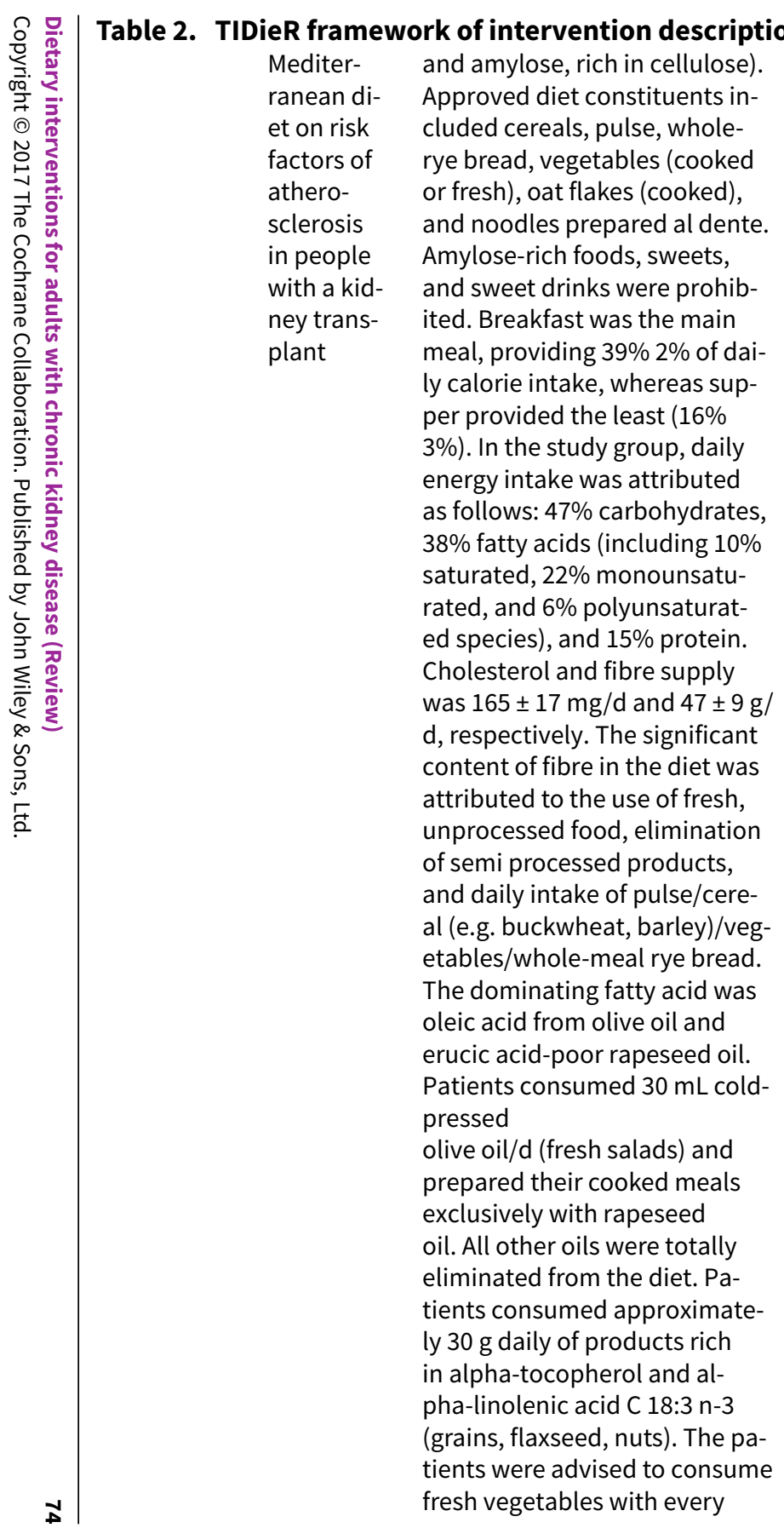

certained

every 4

weeks us-

ing ques-

tionnaires

(24-h food

diaries)

and mon-

itoring

oleic acid

content

in plas-

ma triglyc-

erides triglyc-

erides

contin-

ued to in-

crease in

the study

group and

remained

un-

changed

in controls

(Table 2)

as follows: $47 \%$ carbohydrates,

was $165 \pm 17 \mathrm{mg} / \mathrm{d}$ and $47 \pm 9 \mathrm{~g} /$

, respectively. The significant

.

attributed to the use of fresh,

of semi processed products,

and daily intake of pulse/cere-

l (e.g. buckwheat, barley)/veg-

The dominating fatty acid was

oleic acid from olive oil and

erucic acid-poor rapeseed oil.

Pressed consumed $30 \mathrm{~mL}$ cold

prepared their cooked meals

Alvely with rapeseed

the diet. Pa-

ly $30 \mathrm{~g}$ daily of products rich

-

(grains, flaxseed, nuts). The pa-

fresh vegetables with every 


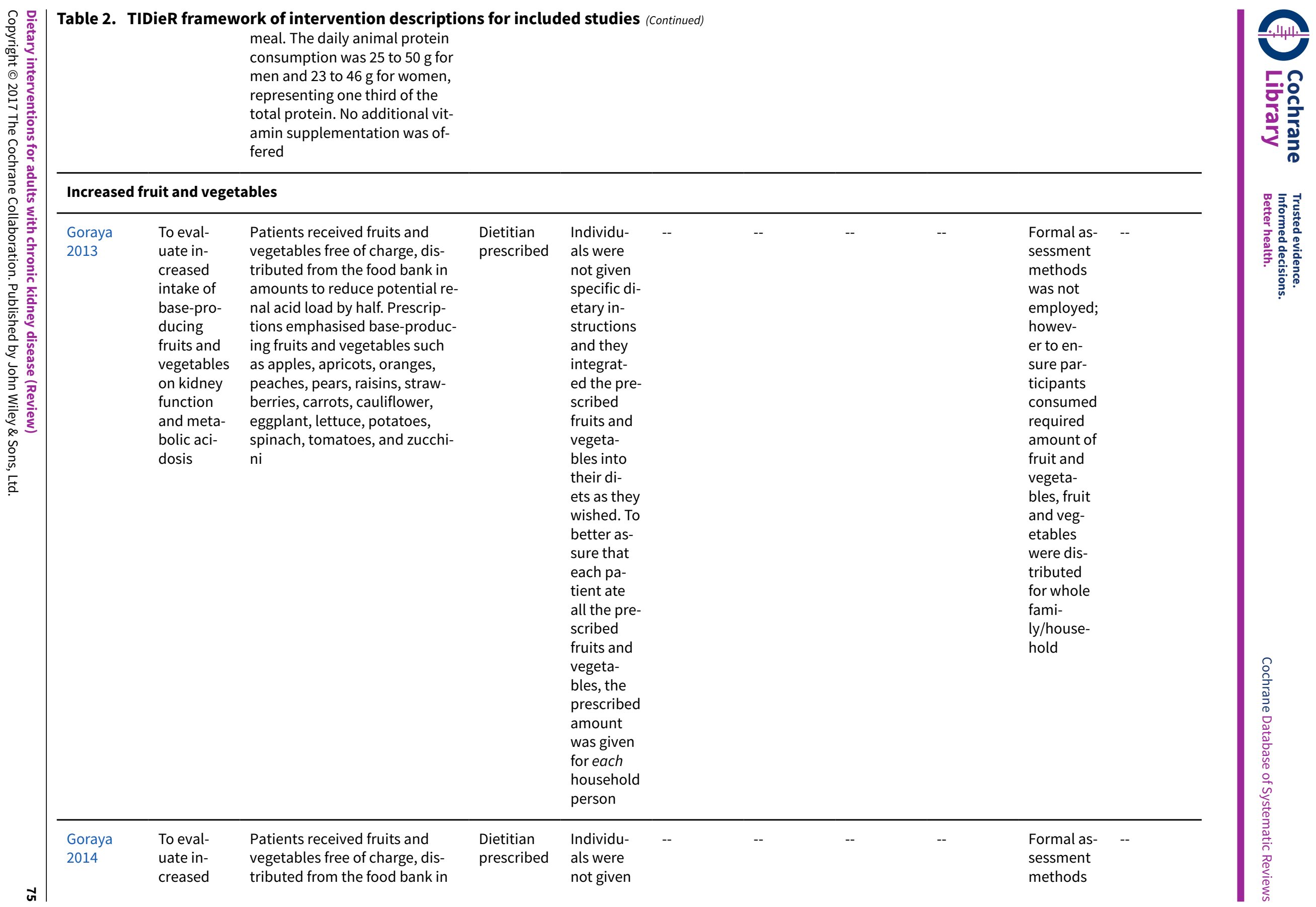




\begin{tabular}{|c|c|c|c|c|c|c|c|c|c|c|}
\hline & $\begin{array}{l}\text { intake of } \\
\text { base-pro- } \\
\text { ducing } \\
\text { fruits and } \\
\text { vegetables } \\
\text { on kidney } \\
\text { function } \\
\text { and meta- } \\
\text { bolic aci- } \\
\text { dosis }\end{array}$ & $\begin{array}{l}\text { amounts to reduce potential re- } \\
\text { nal acid load by half. Prescrip- } \\
\text { tions emphasised base-produc- } \\
\text { ing fruits and vegetables such } \\
\text { as apples, apricots, oranges, } \\
\text { peaches, pears, raisins, straw- } \\
\text { berries, carrots, cauliflower, } \\
\text { eggplant, lettuce, potatoes, } \\
\text { spinach, tomatoes, and zucchi- } \\
\text { ni }\end{array}$ & & $\begin{array}{l}\text { spe } \\
\text { etar } \\
\text { stru } \\
\text { and } \\
\text { inte } \\
\text { ed t } \\
\text { scril } \\
\text { fruit } \\
\text { veg } \\
\text { bles } \\
\text { thei } \\
\text { ets } \\
\text { wish } \\
\text { bett } \\
\text { sure } \\
\text { eacl } \\
\text { tien } \\
\text { all t } \\
\text { scrit } \\
\text { fruit } \\
\text { veg } \\
\text { bles } \\
\text { pres } \\
\text { amc } \\
\text { was } \\
\text { for } \\
\text { hou } \\
\text { pers }\end{array}$ & & & & & $\begin{array}{l}\text { was not } \\
\text { employed; } \\
\text { howev- } \\
\text { er to en- } \\
\text { sure par- } \\
\text { ticipants } \\
\text { consumed } \\
\text { required } \\
\text { amount of } \\
\text { fruit and } \\
\text { vegeta- } \\
\text { bles, fruit } \\
\text { and veg- } \\
\text { etables } \\
\text { were dis- } \\
\text { tributed } \\
\text { for whole } \\
\text { fami- } \\
\text { ly/house- } \\
\text { hold }\end{array}$ & \\
\hline \multicolumn{11}{|c|}{ Carbohydrate-restricted, low-iron, polyphenol enriched (CR-LIPE) diet } \\
\hline $\begin{array}{l}\text { Facchini } \\
2003\end{array}$ & $\begin{array}{l}\text { To eval- } \\
\text { uate } \\
\text { whether } \\
\text { dietary } \\
\text { modifica- } \\
\text { tion had } \\
\text { effect on } \\
\text { progres- } \\
\text { sion of } \\
\text { CKD }\end{array}$ & $\begin{array}{l}\text { CR-LIPE diet; } 50 \% \text { reduction in } \\
\text { carbohydrate intake; substi- } \\
\text { tution of iron-enriched meats } \\
\text { (beef and pork) with iron-poor } \\
\text { white meats (poultry and fish) } \\
\text { and with protein-enriched food } \\
\text { items known to inhibit iron } \\
\text { absorption (dairy; eggs; soy); } \\
\text { elimination of all beverages } \\
\text { other than tea, water and red } \\
\text { wine; exclusive use of polyphe- } \\
\text { nol-enriched extra-virgin olive } \\
\text { oil }\end{array}$ & & -- & -- & -- & -- & -- & $\begin{array}{l}\text { Serum fer- } \\
\text { ritin level; } \\
\text { to assess } \\
\text { adherence } \\
\text { with low } \\
\text { iron diet }\end{array}$ & $\begin{array}{l}\text { Serum fer- } \\
\text { ritin level } \\
\text { decreased } \\
\text { in group } \\
\text { on CR-LIPE } \\
\text { diet }\end{array}$ \\
\hline
\end{tabular}




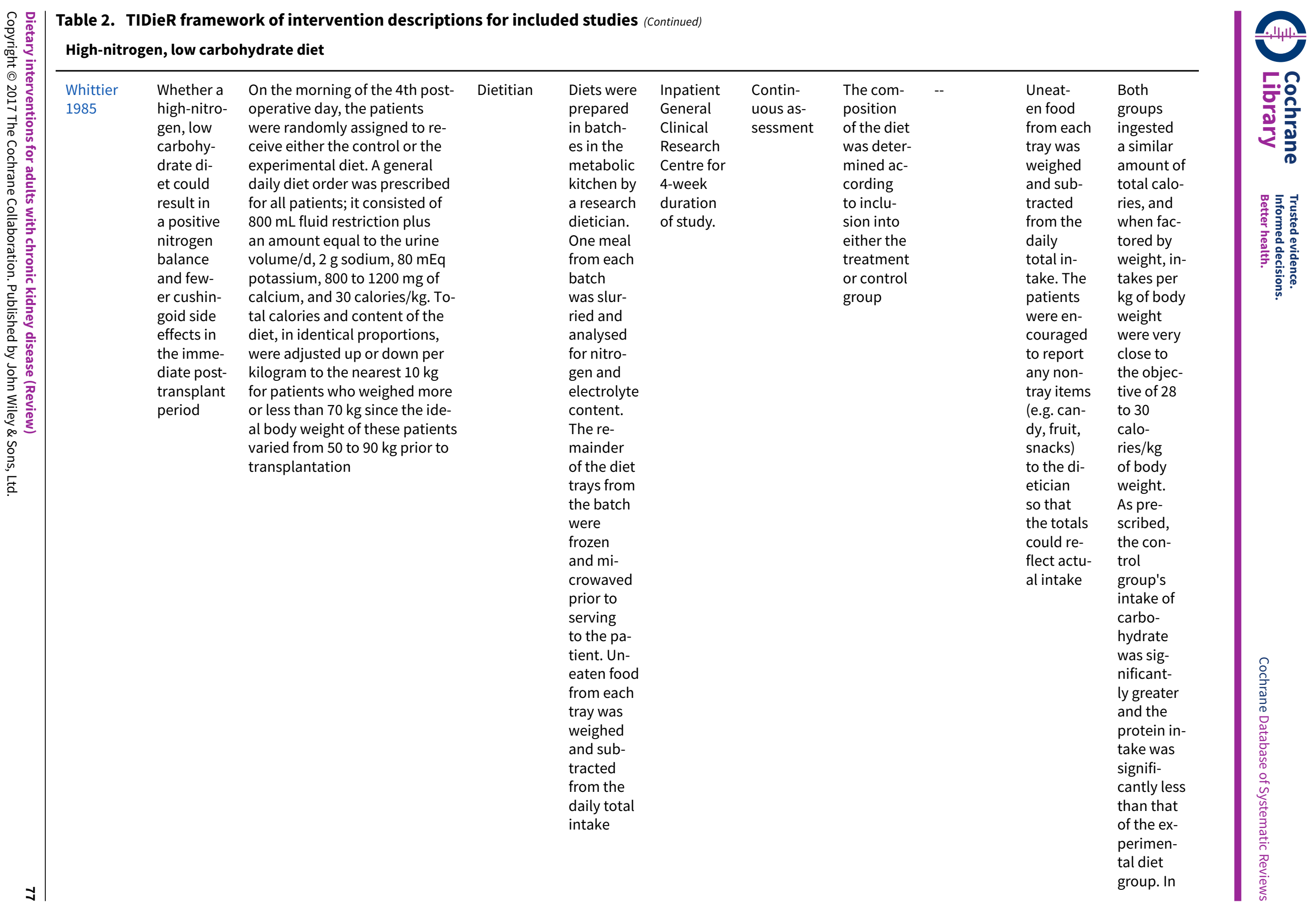


Table 2. TIDieR framework of intervention descriptions for included studies (Continued)

the con-

trol group

there was

little vari-

ation in

protein or

caloric in-

take from

patient to

patient

with the

exception

of patient

9, whereas

in the ex-

perimen

tal group,

the pro-

tein in-

take var-

ied from

$1.4 \mathrm{~g} / \mathrm{kg} / \mathrm{d}$

up to the

up to the

goal of 3.0
$\mathrm{~g} / \mathrm{kg} / \mathrm{d}$

BMI - body mass index; (I)BW - (individual) body weight- CKD - chronic kidney disease; eGFR - estimated glomerular filtration rate; GI - glycaemic index 
Table 3. Narrative description of health-related quality of life outcomes

\begin{tabular}{ll}
\hline Study ID & Tool \\
\hline Dietary counselling & \\
\hline Campbell 2008 & $\begin{array}{l}\text { Kidney Disease Quality } \\
\text { of Life Short Form Ver- } \\
\text { sion } 1.3 \text { (combining the } \\
\text { SF-36 with a kidney-dis- } \\
\text { ease specific module) }\end{array}$
\end{tabular}

Description

\begin{tabular}{lll}
\hline Chanwikrai 2012 & Not reported \\
\hline Flesher 2011 & $\begin{array}{ll}\text { Self-Management Ques- } \\
\text { tionnaire }\end{array}$ & "Overall, the experimental group showed 'improvement' in exercise frequen- \\
& cy, concern over health condition, and frequency of visits to health providers \\
& or hospitalisation. Overall the control group answers indicated an improve- \\
& ment in their communication with health providers in asking question and dis- \\
& cussing personal issues."
\end{tabular}

\begin{tabular}{|c|c|c|}
\hline Leon 2006 & $\begin{array}{l}\text { Kidney Disease Quali- } \\
\text { ty of Life questionnaire } \\
\text { (combining the SF-36 } \\
\text { with a kidney-disease } \\
\text { specific module) }\end{array}$ & $\begin{array}{l}\text { "There were no differences between intervention and control patients in qual- } \\
\text { ity-of-life subscales, including general health, physical functioning, emotional } \\
\text { well-being, social function, pain, and dialysis-related symptoms." }\end{array}$ \\
\hline Orazio 2011 & -- & Not reported \\
\hline Riccio 2014 & -- & Not reported \\
\hline Sutton 2007 & -- & Not reported \\
\hline Teng 2013 & $\begin{array}{l}\text { 52-item HPLP-IIC ques- } \\
\text { tionnaire }\end{array}$ & $\begin{array}{l}\text { Intervention had a significant effect on health responsibility and physical ac- } \\
\text { tivity, but not stress management, interpersonal relations, spiritual growth or } \\
\text { nutrition }\end{array}$ \\
\hline Tzvetanov 2014 & SF-36 & $\begin{array}{l}\text { "The mean SF- } 36 \text { score at } 6 \text { months was significantly higher in the intervention } \\
\text { group compared with the control group ( } 583 \pm 13 \text { vs } 436 \pm 22, P=0.008) \text {, reflect- } \\
\text { ing an improved perception of health status. ... The intervention group had im- } \\
\text { provements compared with the control group in the domains of vitality and } \\
\text { general health." }\end{array}$ \\
\hline Zhou 2011b & $\begin{array}{l}\text { Kidney Disease Quality } \\
\text { of Life Short Form Ver- } \\
\text { sion } 1.3 \text { (combining the } \\
\text { SF- } 36 \text { with a kidney-dis- } \\
\text { ease specific module) }\end{array}$ & $\begin{array}{l}\text { "Prior to intervention, the differences in KDTA and SF- } 36 \text { scores were not sta- } \\
\text { tistically significant in both groups }(P>0.05 \text { for all). After intervention, both KD- } \\
\text { TA and SF- } 36 \text { scores were improved in the study group, but decreased in the } \\
\text { control group. The difference in KDTA }(P=0.001) \text { and SF- } 36 \text { scores }(P=0.001) \\
\text { before and after intervention were statistically significant in both groups (Ta- } \\
\text { ble 2)." }\end{array}$ \\
\hline
\end{tabular}

\begin{tabular}{lll}
\hline Mediterranean diet & \\
\hline DIRECT Study 2013 & -- & Not reported \\
\hline Mekki 2010 & -- & Not reported \\
\hline Stachowska 2005 & -- & Not reported \\
\hline
\end{tabular}


Table 3. Narrative description of health-related quality of life outcomes (Continued)

\section{Increased fruit and vegetables}

\begin{tabular}{lll}
\hline Goraya 2013 & - & Not reported \\
\hline Goraya 2014 & -- & Not reported
\end{tabular}

\section{Carbohydrate-restricted, low-iron-available, polyphenol-enriched diet}

Facchini $2003 \quad$-- Not reported

\section{High-protein, low carbohydrate diet}

Whittier $1985 \quad--\quad$ Not reported

\section{Table 4. Adverse events}

\begin{tabular}{|c|c|}
\hline Study & Adverse events reported in study \\
\hline Campbell 2008a & Mortality; need for dialysis \\
\hline Chanwikrai 2012 & Not reported \\
\hline DIRECT Study 2013 & Not reported \\
\hline Facchini 2003 & Not reported \\
\hline Flesher 2011 & Not reported \\
\hline Goraya 2013 & $\begin{array}{l}\text { No participants meeting eGFR and plasma potassium criteria developed plasma potas- } \\
\text { sium concentration }>5.0 \mathrm{mEq} / \mathrm{L}\end{array}$ \\
\hline Goraya 2014 & Not reported \\
\hline Leon 2006 & Not reported \\
\hline Mekki 2010 & Not reported \\
\hline Orazio 2011 & Not reported \\
\hline Riccio 2014 & Not reported \\
\hline Stachowska 2005 & Not reported \\
\hline Sutton 2007 & Mortality; transfer from PD to HD \\
\hline Teng 2013 & Not reported \\
\hline Tzvetanov 2014 & Not reported \\
\hline Whittier 1985 & Dialysis due to elevated blood urea and potassium concentrations \\
\hline Zhou 2011b & Not reported \\
\hline
\end{tabular}

eGFR - estimated glomerular filtration rate; HD - haemodialysis; PD - peritoneal dialysis 


\section{A P PE N D I CES}

\section{Appendix 1. Electronic search strategies}

\begin{tabular}{|c|c|}
\hline Database & Search terms \\
\hline \multirow[t]{38}{*}{ CENTRAL } & 1. MeSH descriptor: [Diet] explode all trees \\
\hline & 2. MeSH descriptor: [Diet Therapy] explode all trees \\
\hline & 3. MeSH descriptor: [Dietary Carbohydrates] explode all trees \\
\hline & 4. MeSH descriptor: [Calcium, Dietary] this term only \\
\hline & 5. MeSH descriptor: [Potassium, Dietary] this term only \\
\hline & 6. MeSH descriptor: [Dietary Fats] explode all trees \\
\hline & 7. MeSH descriptor: [Dietary Fiber] explode all trees \\
\hline & 8. MeSH descriptor: [Dietary Proteins] explode all trees \\
\hline & 9. MeSH descriptor: [Dietary Supplements] this term only \\
\hline & 10.MeSH descriptor: [Micronutrients] explode all trees \\
\hline & 11.MeSH descriptor: [Nutritional Requirements] explode all trees \\
\hline & 12.MeSH descriptor: [Nutritional Status] this term only \\
\hline & 13.MeSH descriptor: [Nutrition Therapy] this term only \\
\hline & 14.MeSH descriptor: [Keto Acids] explode all trees \\
\hline & 15.MeSH descriptor: [Amino Acids, Essential] explode all trees \\
\hline & 16. MeSH descriptor: [Folic Acid] this term only \\
\hline & 17.MeSH descriptor: [Patient Education as Topic] this term only \\
\hline & 18.diet\$ or nutrition\$:ti,ab,kw (Word variations have been searched) \\
\hline & 19. $\{$ and \#17-\#18\} \\
\hline & $\begin{array}{l}\left.\text { 20. (diet }{ }^{*} \text { or nutrition }{ }^{\star}\right) \text { and (protein or fat or cholesterol or omega- } 3^{*} \text { or carbohydrates or glyc?emic } \\
\text { index or fibre or fiber or folate or folic acid):ti,ab,kw (Word variations have been searched) }\end{array}$ \\
\hline & $\begin{array}{l}\text { 21.(diet }{ }^{\star} \text { or nutrition*) and (mediterranean or vegetarian or DASH or macrobiotic):ti,ab,kw (Word } \\
\text { variations have been searched) }\end{array}$ \\
\hline & $\begin{array}{l}\text { 22. (diet* or nutrition*) and (phosphorus or calcium or potassium or micronutrient* or vita- } \\
\left.\text { min }^{\star}\right): \text { ti,ab,kw (Word variations have been searched) }\end{array}$ \\
\hline & $\begin{array}{l}\left.\text { 23. (diet }{ }^{\star} \text { or nutrition }{ }^{\star}\right) \text { and (supplement* or amino acid* or keto acid*):ti,ab,kw (Word variations } \\
\text { have been searched) }\end{array}$ \\
\hline & $\begin{array}{l}\left.\text { 24. (diet\$ or nutrition }{ }^{\star}\right) \text { and (advice* or education* or counselling):ti,ab,kw (Word variations have } \\
\text { been searched) }\end{array}$ \\
\hline & 25. $\{$ or \#1-\#16,\#19-\#24\} \\
\hline & 26.MeSH descriptor: [Kidney Diseases] explode all trees \\
\hline & 27.MeSH descriptor: [Renal Replacement Therapy] explode all trees \\
\hline & 28.MeSH descriptor: [Renal Insufficiency] explode all trees \\
\hline & 29.MeSH descriptor: [Renal Insufficiency, Chronic] explode all trees \\
\hline & 30.dialysis:ti,ab,kw (Word variations have been searched) \\
\hline & 31.hemodialysis or haemodialysis:ti,ab,kw (Word variations have been searched) \\
\hline & 32.hemofiltration or haemofiltration:ti,ab,kw (Word variations have been searched) \\
\hline & 33.hemodiafiltration or haemodiafiltration:ti,ab,kw (Word variations have been searched) \\
\hline & $\begin{array}{l}\text { 34.kidney disease* or renal disease }{ }^{\star} \text { or kidney failure or renal failure:ti,ab,kw (Word variations have } \\
\text { been searched) }\end{array}$ \\
\hline & 35.ESRF or ESKF or ESRD or ESKD:ti,ab,kw (Word variations have been searched) \\
\hline & 36.CKF or CKD or CRF or CRD:ti,ab,kw (Word variations have been searched) \\
\hline & 37.CAPD or CCPD or APD:ti,ab,kw (Word variations have been searched) \\
\hline & 38.predialysis or pre-dialysis:ti,ab,kw (Word variations have been searched) \\
\hline
\end{tabular}


39.MeSH descriptor: [Diabetic Nephropathies] this term only

40.diabetic kidney disease ${ }^{\star}: t i, a b, k w$ (Word variations have been searched)

41.diabetic nephropath*:ti,ab,kw (Word variations have been searched)

42. $\{$ or \#26-\#41\}

43. $\{$ and \#25, \#42\}
1. Diet/

2. Diet Therapy/

3. Caloric Restriction/

4. Diabetic Diet/

5. Diet, Carbohydrate-Restricted/

6. Diet, Fat-Restricted/

7. Diet, Gluten-free/

8. Diet, Macrobiotic/

9. Diet, High-Fat/

10.Diet, Mediterranean/

11.Diet, Paleolithic/

12.Diet, Protein-Restricted/

13.Diet, Reducing/

14.Diet, Sodium-Restricted/

15.Diet, Vegetarian/

16.Diet, Atherogenic/

17.Diet Fads/

18.Diet, Cariogenic/

19.Diet, Western/

20.exp Dietary Carbohydrates/

21.Calcium, Dietary/

22.Potassium, Dietary/

23.exp Dietary Fats/

24.exp Dietary Fiber/

25.exp Dietary Proteins/

26.Dietary Supplements/

27.exp Micronutrients/

28.exp Nutritional Requirements/

29.Nutritional Status/

30.Nutrition Therapy/

31.Energy Intake/

32.Fasting/

33.ketogenic diet/

34.Portion Size/ or Serving Size/

35.exp Keto Acids/

36.exp Amino Acids, Essential/

37.exp Amino Acids/

38. Folic Acid/

39.Patient Education as Topic/

40.(diet\$ and (mediterranean or vegetarian or DASH)).tw.

41. (diet\$ and (supplement\$ or amino acid\$ or amino acids or keto acid\$)).tw.

42.((diet\$ or nutrition\$) and (advice or education\$ or counselling)).tw.

43.or/1-42

44. Kidney Diseases/

45.exp Renal Replacement Therapy/

46. Renal Insufficiency/ 


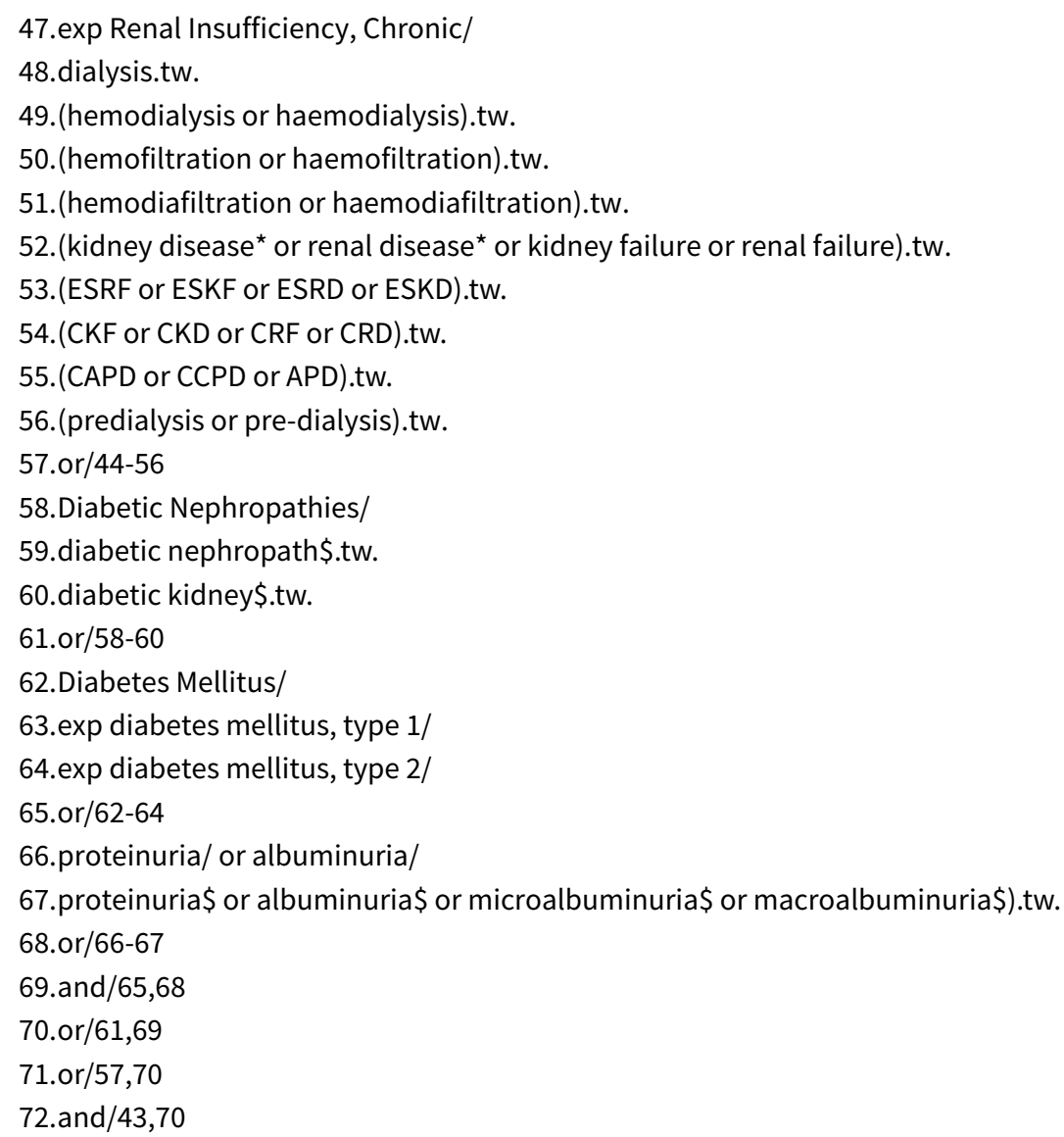

2. nutrition education/

3. nutritional health/

4. nutritional assessment/

5. nutrition/

6. exp diet/

7. exp diet therapy/

8. exp dietary intake/

9. exp diet restriction/

10. or/1-9

11. exp renal replacement therapy/

12. kidney disease/

13. chronic kidney disease/

14. kidney failure/

15. chronic kidney failure/

16. mild renal impairment/ 

17. stage 1 kidney disease/
18. moderate renal impairment/
19. severe renal impairment/
20. end stage renal disease/

21. renal replacement therapy-dependent renal disease/

22. kidney transplantation/

23. (hemodialysis or haemodialysis).tw.

24. (hemofiltration or haemofiltration).tw.

25. (hemodiafiltration or haemodiafiltration).tw.

26. dialysis.tw.

27. (CAPD or CCPD or APD).tw.

28. (kidney disease* or renal disease* or kidney failure or renal failure).tw.

29. (CKF or CKD or CRF or CRD).tw.

30. (ESRF or ESKF or ESRD or ESKD).tw.

31. (predialysis or pre-dialysis).tw.

32. ((kidney or renal) adj (transplant ${ }^{\star}$ or graft $^{\star}$ or allograft $\left.\left.{ }^{\star}\right)\right)$.tw.

33. Diabetic Nephropathies/

34. diabetic nephropath\$̣.tw.

35. diabetic kidney disease $\$ . t w$.

36. or/11-35

37. and $/ 10,36$

\section{Appendix 2. Risk of bias assessment tool}

\section{Potential source of bias \\ Random sequence genera- tion}

\section{Assessment criteria}

Selection bias (biased allocation to interventions) due to inadequate generation of a randomised sequence
Low risk of bias: Random number table; computer random number generator; coin tossing; shuffling cards or envelopes; throwing dice; drawing of lots; minimization (minimization may be implemented without a random element, and this is considered to be equivalent to being random).

High risk of bias: Sequence generated by odd or even date of birth; date (or day) of admission; sequence generated by hospital or clinic record number; allocation by judgement of the clinician; by preference of the participant; based on the results of a laboratory test or a series of tests; by availability of the intervention.

Unclear: Insufficient information about the sequence generation process to permit judgement.

\section{Allocation concealment}

Selection bias (biased allocation to interventions) due to

Low risk of bias: Randomisation method described that would not allow investigator/participant to know or influence intervention group before eligible participant entered in the study (e.g. central allocation, including telephone, web-based, and pharmacy-controlled, randomisation; sequential- 
(Continued)

inadequate concealment of allocations prior to assignment ly numbered drug containers of identical appearance; sequentially numbered, opaque, sealed envelopes).

High risk of bias: Using an open random allocation schedule (e.g. a list of random numbers); assignment envelopes were used without appropriate safeguards (e.g. if envelopes were unsealed or non-opaque or not sequentially numbered); alternation or rotation; date of birth; case record number; any other explicitly unconcealed procedure.

Unclear: Randomisation stated but no information on method used is available.

\section{Blinding of participants and personnel}

Performance bias due to knowledge of the allocated interventions by participants and personnel during the study
Low risk of bias: No blinding or incomplete blinding, but the review authors judge that the outcome is not likely to be influenced by lack of blinding; blinding of participants and key study personnel ensured, and unlikely that the blinding could have been broken.

High risk of bias: No blinding or incomplete blinding, and the outcome is likely to be influenced by lack of blinding; blinding of key study participants and personnel attempted, but likely that the blinding could have been broken, and the outcome is likely to be influenced by lack of blinding.

\section{Blinding of outcome assess- ment}

Detection bias due to knowledge of the allocated interventions by outcome assessors.

Unclear: Insufficient information to permit judgement

Low risk of bias: No blinding of outcome assessment, but the review authors judge that the outcome measurement is not likely to be influenced by lack of blinding; blinding of outcome assessment ensured, and unlikely that the blinding could have been broken.

High risk of bias: No blinding of outcome assessment, and the outcome measurement is likely to be influenced by lack of blinding; blinding of outcome assessment, but likely that the blinding could have been broken, and the outcome measurement is likely to be influenced by lack of blinding.

Unclear: Insufficient information to permit judgement

\section{Incomplete outcome data}

Attrition bias due to amount, nature or handling of incomplete outcome data.
Low risk of bias: No missing outcome data; reasons for missing outcome data unlikely to be related to true outcome (for survival data, censoring unlikely to be introducing bias); missing outcome data balanced in numbers across intervention groups, with similar reasons for missing data across groups; for dichotomous outcome data, the proportion of missing outcomes compared with observed event risk not enough to have a clinically relevant impact on the intervention effect estimate; for continuous outcome data, plausible effect size (difference in means or standardized difference in means) among missing outcomes not enough to have a clinically relevant impact on observed effect size; missing data have been imputed using appropriate methods.

High risk of bias: Reason for missing outcome data likely to be related to true outcome, with either imbalance in numbers or reasons for missing data across intervention groups; for dichotomous outcome data, the proportion of missing outcomes compared with observed event risk enough to induce clinically relevant bias in intervention effect estimate; for continuous outcome data, plausible effect size (difference in means or standardized difference in means) among missing outcomes enough to induce clinically relevant bias in observed effect size; 'as-treated' analysis done with substantial departure of the intervention received from that assigned at randomisation; potentially inappropriate application of simple imputation.

Unclear: Insufficient information to permit judgement

Low risk of bias: The study protocol is available and all of the study's pre-specified (primary and secondary) outcomes that are of interest in the review have been reported in the pre-specified way; the study protocol is not available but it is clear that the published reports include all expected outcomes, including those that were pre-specified (convincing text of this nature may be uncommon).

High risk of bias: Not all of the study's pre-specified primary outcomes have been reported; one or more primary outcomes is reported using measurements, analysis methods or subsets of the data (e.g. subscales) that were not pre-specified; one or more reported primary outcomes were not prespecified (unless clear justification for their reporting is provided, such as an unexpected adverse 
effect); one or more outcomes of interest in the review are reported incompletely so that they cannot be entered in a meta-analysis; the study report fails to include results for a key outcome that would be expected to have been reported for such a study.

Unclear: Insufficient information to permit judgement

\section{Other bias}

Bias due to problems not covered elsewhere in the table
Low risk of bias: The study appears to be free of other sources of bias.

High risk of bias: Had a potential source of bias related to the specific study design used; stopped early due to some data-dependent process (including a formal-stopping rule); had extreme baseline imbalance; has been claimed to have been fraudulent; had some other problem.

Unclear: Insufficient information to assess whether an important risk of bias exists; insufficient rationale or evidence that an identified problem will introduce bias.

\section{CONTRIBUTIONS OF AUTHORS}

1. Draft the protocol: SP, GS, KC, JC, AT

2. Study selection: SP, JM

3. Extract data from studies: SP, JM

4. Enter data into RevMan: SP, JM

5. Carry out the analysis: SP, JM

6. Interpret the analysis: All authors

7. Draft the final review: All authors

8. Disagreement resolution: $\mathrm{KC}$

9. Update the review: SP, GS

\section{DECLARATIONS OF INTEREST}

- Suetonia C Palmer: none known

- Jasjot Maggo: none known

- Allison Tong: none known

- Katrina L Campbell: none known

- Jonathan C Craig: none known

- David W Johnson: none known

- Bernadet Sutanto: none known

- Marinella Ruospo: none known

- Giovanni FM Strippoli: none known

DIFFERENCES BETWEEN PROTOCOLAND REVIEW

None.

\section{INDEX TERMS}

\section{Medical Subject Headings (MeSH)}

Cardiovascular Diseases [epidemiology]; Diet, Carbohydrate-Restricted [statistics \& numerical data]; Diet, Mediterranean [statistics \& numerical data]; Diet, Protein-Restricted [statistics \& numerical data]; Disease Progression; Fruit; Kidney Failure, Chronic [diet therapy] [mortality]; Kidney Transplantation [statistics \& numerical data]; Quality of Life; Randomized Controlled Trials as Topic; Renal Insufficiency, Chronic [ ${ }^{\star}$ diet therapy] [mortality]; Renal Replacement Therapy [statistics \& numerical data]; Vegetables

\section{MeSH check words}

Adult; Humans 